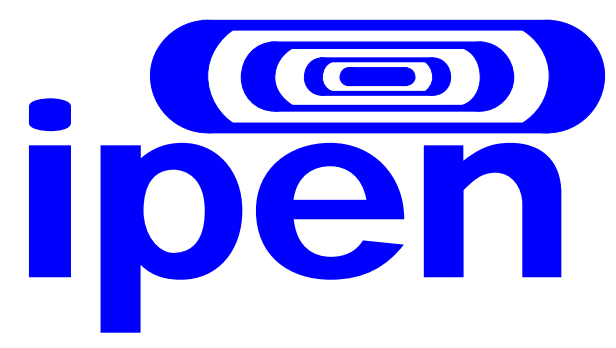

INSTITUTO DE PESQUISAS ENERGÉTICAS E NUCLEARES

Autarquia Associada à Universidade de São Paulo

ESTUDO DA IMOBILIZAÇÃO DE REJEITOS RADIOATIVOS EM MATRIZES ASFÁLTICAS E RESÍDUOS ELASTOMÉRICOS

UTILIZANDO A TÉCNICA DE MICROONDAS

REINALDO LEONEL CARATIN

Dissertação apresentada como parte dos requisitos para obtenção do Grau de Mestre em Ciências na Área de Tecnologia Nuclear - Materiais.

Orientadora: Dr. ${ }^{\text {a }}$ Sumair Gouveia de Araújo

São Paulo 
Dedico este trabalho à minha esposa, Rosiris, pelo amor, incentivo, paciência e dedicação, à minha filha, Priscila, pelo companheirismo, à minha mãe, Wanda, pela educação e à minha sogra, Joanna, pelo carinho. 


\section{AGRADECIMENTOS}

Ao Instituto de Pesquisas Energéticas e Nucleares (IPEN-CNEN/SP), pela possibilidade de desenvolver este trabalho.

À Dr. ${ }^{a}$ Sumair Gouveia de Araújo, por sua orientação na escolha do tema, nas precisas intervenções e pela autonomia permitida na elaboração deste trabalho.

Aos colegas do Centro de Química e Meio Ambiente (CQMA-IPEN):

Dr. ${ }^{a}$ Casuê Nakanishi, por sua ajuda na obtenção das resinas;

Dr. ${ }^{a}$ Christina A.L.G. de O. Forbicini, por sua paciência, discussões e colaboração na fase da separação do zinco;

Dr. ${ }^{a}$ Duclerc F. Parra e Srta. Heloísa A. Zen, pelos ensaios TGA;

Dr. ${ }^{a}$ Liliane Landini, pela sua dedicação;

Eng. ${ }^{a}$ Sabrina Cabrera, pela parceria nos procedimentos laboratoriais;

Dr. ${ }^{a}$ Sizue O. Rogero e Dr. ${ }^{a}$ Mitiko Yamaura, pela disponibilização e preparo das amostras de magnetita;

Dr. Ademar Benévolo Lugão, pelas sugestões e material disponibilizado;

Dr. Alcídio Abrão, pelas discussões e material disponibilizado;

Dr. Paulo E. Lainetti, pelo incentivo e empréstimo de um espaço no laboratório de análises térmicas.

Aos colegas do Centro de Ciência e Tecnologia de Materiais (CCTM-IPEN):

Eng. ${ }^{a}$ Raquel M. Lobo e Sr. Nildemar A. M. Ferreira, que calmamente focaram as matrizes na elaboração das micrografias.

Aos colegas do Laboratório de Rejeitos Radioativos (LRR-IPEN):

Dr. $^{a}$ Bárbara Rzyzki, Dr. Goro Hiromoto e Dr. Roberto Vicente, pelo interesse e sugestões neste trabalho;

Sra. Vera Lúcia Keiko Isiki e Dr. Júlio Takehiro Marumo, pelas contagens das amostras dos ensaios de lixiviação.

Aos colegas do Serviço de Rádio Proteção (SRP-IPEN):

Dr. $^{a}$ Terezinha de Moraes da Silva, MSc. Francisco Mário Feijó Marques e

Sr. Robson de Jesus Ferreira, nos cuidados para a armazenagem segura do ${ }^{65} \mathrm{Zn}$.

Aos bibliotecários do IPEN, pela paciente e permanente ajuda prestada:

Sra. Edna Maria Alves, Sra. Maria Eneide de Souza Araújo, MSc. Mery

Piedad Zamudio Igami e Sr. Waldir Ferreira. 
Ao colega do Núcleo de Inovação Tecnológica (NITEC):

Sr. Roberto Márcio de M. Fraga, pelo apoio na diagramação e impressão de partes deste trabalho.

Aos colegas do Departamento de Projetos e Obras (DPO):

Arq. ${ }^{a}$ Elizabeth Brigagão de Faria Lainetti e Arq. Luiz Massi Jr. por executarem parte das minhas atividades diárias;

Sra. Claudia de Fátima de O. Mouro, pela execução dos desenhos.

Eng. ${ }^{\circ}$ Fábio E. de Campos e Sr. Gilberto Magalhães, pela execução da embalagem e blindagem para $0{ }^{65} \mathrm{Zn}$.

Aos queridos amigos e amigas do IPEN que, embora não tenham sido nominalmente citados, estiveram presentes e muitas vezes não entenderam a minha ausência nos nossos eventos, e pela paciência com o meu mau-humor.

À colega do Centro de Desenvolvimento da Tecnologia Nuclear (CDTN):

MSc. Marcia Flavia Righi Guzella, pelas dicas e tranqüila acolhida.

Ao Centro de Tecnologia de Obras de Infra-estrutura (IPT):

Pela realização dos ensaios mecânicos em todas as amostras, coordenados pela Dr. ${ }^{\text {a }}$ Márcia Aps e MSc. Marcus Reis e executados pelo Sr. Luiz B. Adelino.

À Indústria Inajá Artefatos, Copos, Embalagens de Papel Ltda:

Pelo fornecimento das embalagens parafinadas.

À Viapol Ltda:

Pelo fornecimento do cimento asfáltico Vit 90.

À Grendene Calçados S/A:

Pelo fornecimento das amostras de EVA.

Aos meus familiares, pelo apoio incondicional no desenvolvimento desta pesquisa.

À minha esposa, Rosiris Mancini Caratin, pela minuciosa correção ortográfica e gramatical deste trabalho. 


\title{
ESTUDO DA IMOBILIZAÇÃO DE REJEITOS RADIOATIVOS EM MATRIZES ASFÁLTICAS E RESÍDUOS ELASTOMÉRICOS UTILIZANDO A TÉCNICA DE MICROONDAS
}

\author{
Reinaldo Leonel Caratin
}

RESUMO

No presente trabalho, foi utilizada a técnica de aquecimento por microondas para estudar a imobilização de rejeitos radioativos de nível de atividade baixo e médio, como resinas de troca iônica exauridas, empregadas na remoção de íons indesejáveis dos circuitos primários de refrigeração de reatores nucleares refrigerados a água, e aquelas usadas em colunas de separação química e radionuclídica no controle de qualidade de radioisótopos. Matrizes betuminosas reforçadas com alguns tipos de borrachas (Neoprene $®$, Silicone e Etileno Vinil Acetato - EVA), provenientes de material descartado ou sobras de produção, foram utilizadas para incorporação dos rejeitos radioativos. As irradiações das amostras foram feitas em um forno de microondas caseiro, que opera com freqüência de $2.450 \mathrm{MHz}$ e possui potência de $1.000 \mathrm{~W}$. As amostras foram caracterizadas, empregando-se ensaios de penetração, resistência à lixiviação, pontos de amolecimento, fulgor e combustão, termogravimetria e microscopia óptica. Os resultados obtidos mostraram-se compatíveis com os padrões dos componentes das matrizes, indicando que esta técnica é uma alternativa bastante útil aos métodos de imobilização convencionais e para esses tipos de rejeitos radioativos. 


\title{
STUDY OF IMMOBILIZATION OF RADIOACTIVE WASTES IN ASPHALTIC MATRICES AND ELASTOMERIC RESIDUES BY USING MICROWAVE TECHNIQUE
}

\author{
Reinaldo Leonel Caratin
}

\begin{abstract}
In the present work, the technique of microwave heating was used to study the immobilization of low and intermediate activity level radioactive waste, such as spent ion exchange resin used to remove undesirable ions of primary circuits of refrigeration in water refrigerated nuclear reactors, and those used in chemical and radionuclide separation columns in the quality control of radioisotopes.

Bitumen matrices reinforced with some kinds of rubber (Neoprene $\AA$, silicon and ethylene-vinyl-acetate), from production leftovers or scraps, were used for incorporation of radioactive waste. The samples irradiation was made in a home microwave oven that operates at a frequency of $2.450 \mathrm{MHZ}$ with $1.000 \mathrm{~W}$ power. The samples were characterized by developing assays on penetration, leaching resistance, softening, flash and combustion points, thermogravimetry and optical microscopy.

The obtained results were compatible with the pattern of matrices components, which shows that technique is a very useful alternative to conventional immobilization methods and to those kinds of radioactive waste.
\end{abstract}




\section{SUMÁRIO}

Página

1 INTRODUÇÃO

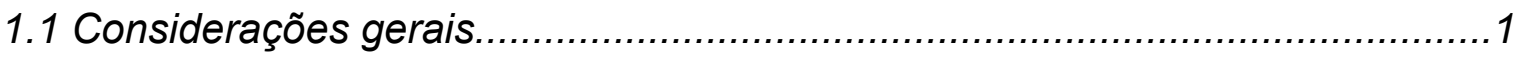

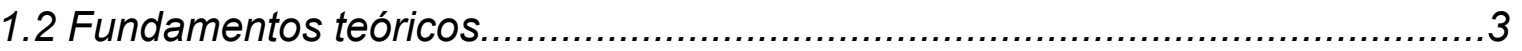

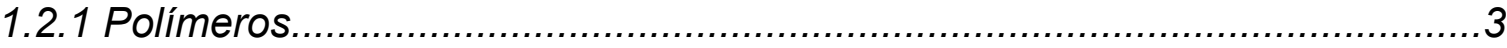

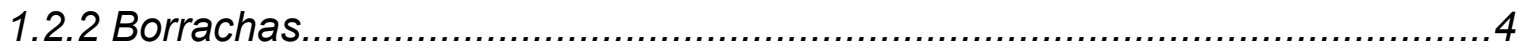

1.2.3 Betume

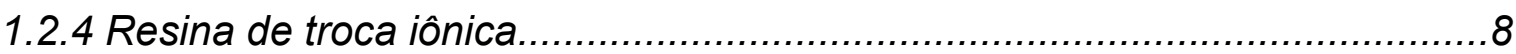

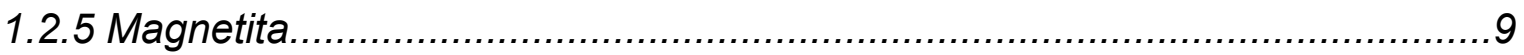

1.2.6 Técnicas de imobilização de rejeitos radioativos.......................................10

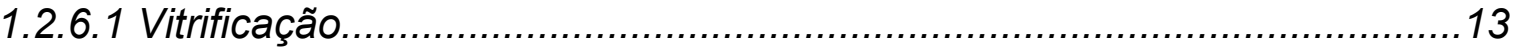

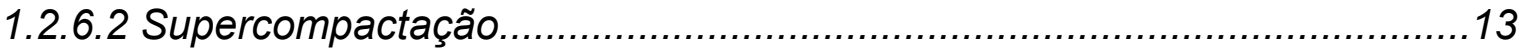

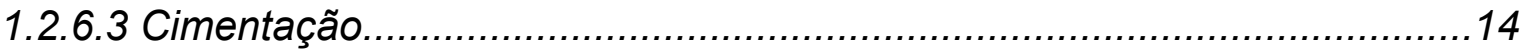

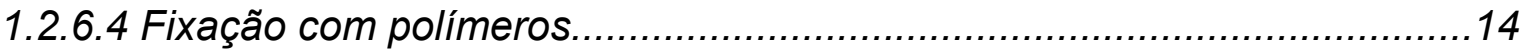

1.2.6.5 Betuminização com extrusora..........................................................16

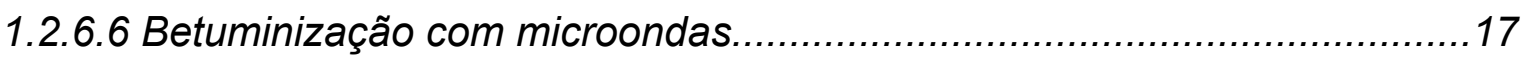

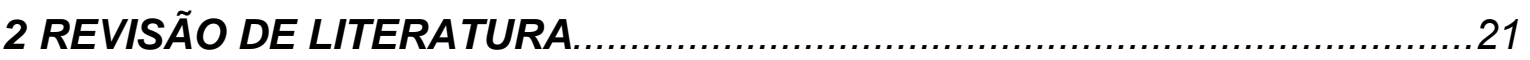

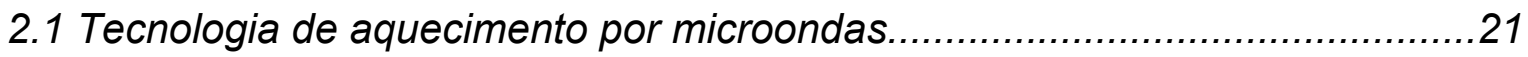

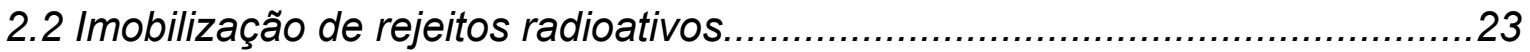

3 OBJETIVOS

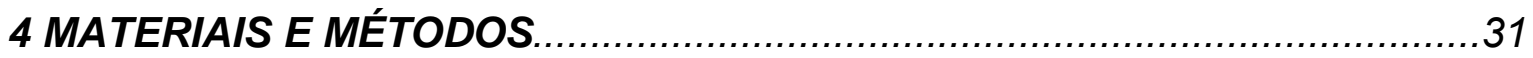

4.1 Amostras.

4.1.1 Borracha

4.1.2 Betume 


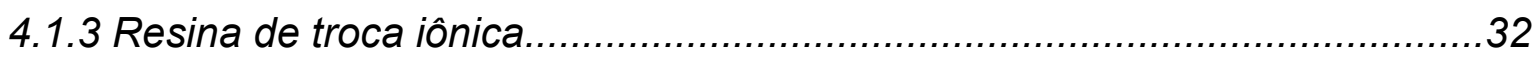

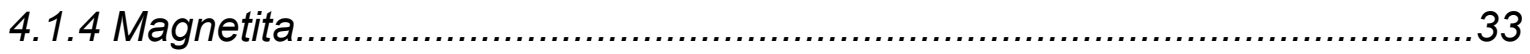

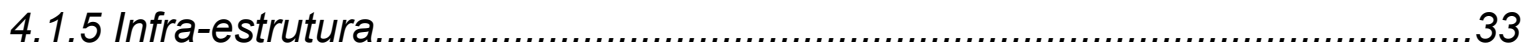

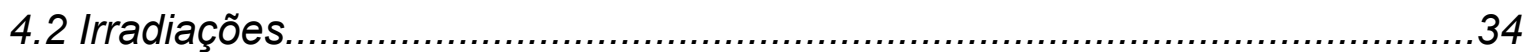

4.2.1 Moldagem de corpos de prova de betume puro e os três polímeros pelo método de banho.......................................................36

4.2.2 Moldagem de corpos de prova com betume, borracha e resina pelo método de banho......................................................... 38

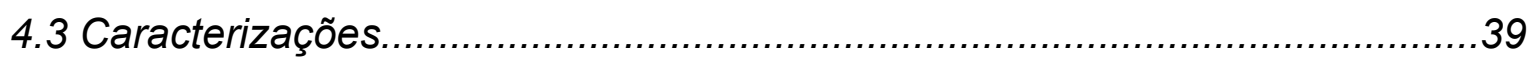

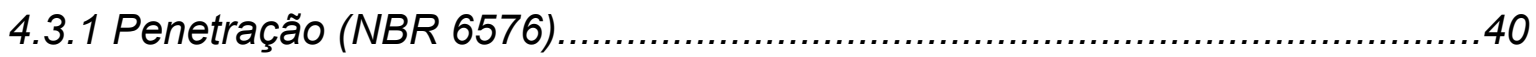

4.3.2 Ponto de amolecimento (6560)...........................................................41

4.3.3 Ponto de fulgor e combustão (NBR 1134)............................................ 41

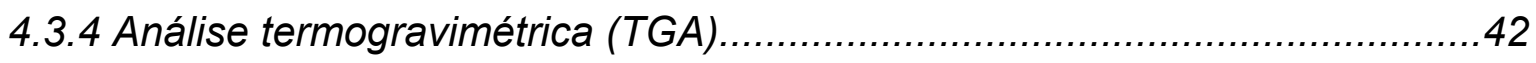

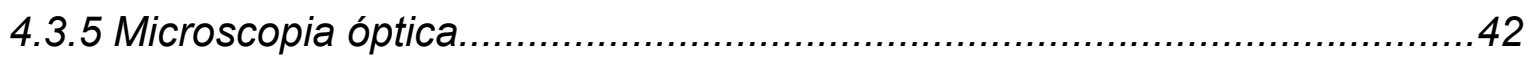

4.3.6 Resistência à lixiviação............................................................. 43

5 RESULTADOS E DISCUSSÕES ......................................................4 45

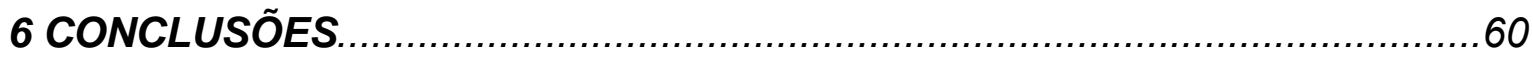

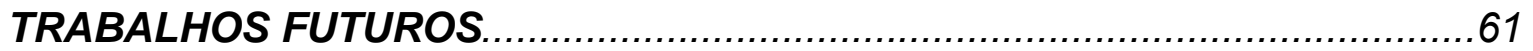

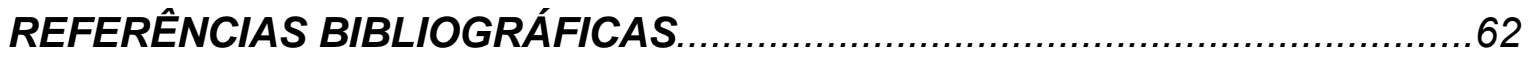




\section{LISTA DE FIGURAS}

Página

1 Representação esquemática do ciclo dos polímeros......................................4

2 Posição dos filtros no circuito primário de um reator nuclear............................9

3 Filtros com resina de troca iônica do Reator IEA-R1/ IPEN..............................9

4 Representação do poder de penetração de emissões $\alpha, \beta, \gamma, X$ e nêutrons......11

5 Diagrama simplificado do gerenciamento de rejeitos radioativos......................12

6 Esquema para encapsulamento de resina exaurida de troca iônica em polímeros................................................................................... 16

7 Fluxograma simplificado de um processo com extrusora.................................17

8 Espectro eletromagnético indicando a freqüência de ondas...........................18

9 Orientação dos momentos dipolo segundo o campo elétrico............................18

10 Formas de reação de materiais sob a ação de radiação eletromagnética.

11 Reação dos materiais sob ação de radiação eletromagnética.

12 Ilustração dos métodos: banho e incorporação de magnetita na matriz de imobilização.

13 Diagrama de montagem do processo de imobilização de resina de troca iônica em matriz de betume e borracha pelo método de banho.

14 Moldagem de um corpo de prova de betume puro.

15 Esquema da montagem do aquecimento de betume em forno microondas.

16 Esquema da montagem do aquecimento de EVA e resina em forno microondas.

17 Moldagem, condicionamento, equipamento para realizar os ensaios e detalhes da penetração da agulha na amostra.

18 Detalhe da moldagem dos corpos de prova e a realização do ensaio de ponto de amolecimento.

19 Ensaio em andamento, ponto de fulgor e ponto de combustão.

20 Padrão $20 \mu{ }^{65} \mathrm{ZnCl}_{2} / \mathrm{g} \mathrm{HCl}$ 0,5mol/l, solução de alimentação, separação pelo processo batelada e geração de efluentes. 
21 Ensaio termogravimétrico em amostra de betume.................................46

22 Magnetita natural sem classificação granulométrica.................................47

23 Comportamento do banho de magnetita para $50 \mathrm{~g}$ de betume....................48

24 Aquecimento de betume em banho de magnetita (exploração 1)...............49

25 Aquecimento de betume em banho de magnetita (exploração 2)................50

26 Aquecimento de betume em chapa aquecedora..................................50

27 Curva de resfriamento do betume puro a partir de $230^{\circ} \mathrm{C} \ldots \ldots \ldots \ldots \ldots \ldots \ldots . . . . . . . . . . . .51$

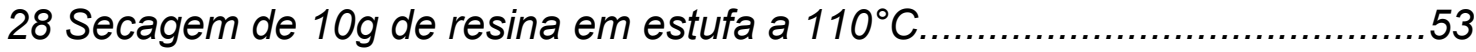

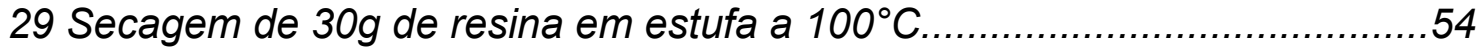

30 Secagem de $10 \mathrm{~g}$ de resina em microondas..............................................54

31 Ensaios de penetração em matrizes de betume, resina e

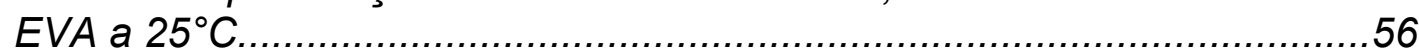

32 MEV da continuidade da superfície do betume sobre a resina.

33 MEV da resina envolta pelo betume no interior da matriz.

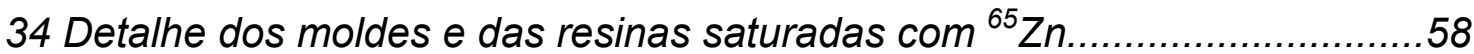

35 Teste de lixiviação, blindagem de chumbo...............................................58 


\section{LISTA DE TABELAS}

Página

1 Especificações do betume tipo cimento asfáltico..................................... 31

2 Especificações da resina tipo Amberlite ${ }^{\circledR}$ - IRN 217...............................33

3 Composição das matrizes de betume e betume/polímero............................35

4 Composição das matrizes de betume, resina e EVA................................39

5 Comparação entre propriedades de asfaltos oxidados padrão

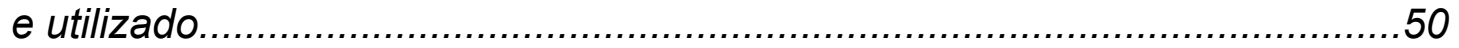

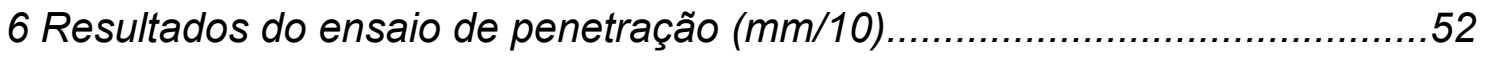

7 Médias dos resultados de caracterização das matrizes...............................53

8 Resultados dos testes de penetração para amostras da fase 2 .....................55

9 Resultados do ensaio de lixiviação...................................................58 


\section{INTRODUÇÃO}

\subsection{Considerações gerais}

Elementos radioativos ocorrem na natureza ou são produzidos por meio de reações nucleares utilizando reatores nucleares ou aceleradores de partículas. Esses tipos de materiais contêm substâncias emissoras de radiação ionizante, ou seja, radiação eletromagnética ou de partículas que, ao interagirem com a matéria, ionizam direta ou indiretamente seus átomos ou moléculas. ${ }^{(1)}$ Eles podem ser empregados em diversas áreas, como indústria e medicina, acarretando, porém, um enorme problema: a geração de rejeitos radioativos. De acordo com a Norma CNEN-NE-6.05, rejeito radioativo é "qualquer material resultante de atividades humanas, que contenha radionuclídeos em quantidades superiores aos limites de isenção especificados na Norma CNEN-NE-6.02 - Licenciamento de Instalações Radiativas, e para o qual sua reutilização é imprópria ou não prevista". (2)

Ao conjunto de atividades operacionais e administrativas para controle desses materiais foi dada a denominação de gerência de rejeitos radioativos, cuja meta principal é garantir proteção à saúde humana e ao meio ambiente hoje e no futuro, sem impor um fardo excessivo às próximas gerações. ${ }^{(3,4)}$

Como os rejeitos radioativos podem ser gerados no estado sólido, líquido ou gasoso, em níveis de atividade baixo, médio ou alto, e cada qual com diferente tempo de meia-vida, foram criados procedimentos e leis para que possam ser manipulados de forma segura durante as etapas de trabalho que vão desde a extração de materiais nucleares naturais, obtenção de produtos e seu transporte, até as fases de tratamento e descarte ou disposição final. ${ }^{(4)}$

Para o tratamento de rejeitos radioativos, vários processos de imobilização considerados convencionais são utilizados em todo o mundo, tais como: vitrificação, supercompactação, cimentação, fixação com polímeros e betuminização com extrusora. Nesta última técnica, o betume e o rejeito radioativo são misturados em uma extrusora, simultaneamente, sob aquecimento e transferidos até uma matriz final por meio de roscas. Este método é empregado 
para rejeitos de baixa e média atividade, proporcionando estruturas química e física estáveis aos materiais enquanto armazenados. ${ }^{(5,6,7)}$

No Brasil, o processo de aquecimento de polímeros com microondas é um campo bem recente e está sendo aplicado como uma nova ferramenta de processamento, com a expectativa de definir os mecanismos de interação dessas ondas eletromagnéticas com esses materiais. Mais especificamente, esse método tem mostrado melhores resultados para polímeros que possuem grupos polares. ${ }^{\left({ }^{(8)}\right.}$

O mecanismo de aquecimento por microondas é aquele no qual a energia é absorvida pela matéria e transformada em energia cinética das moléculas, sendo as partes mais internas e as mais externas aquecidas simultaneamente.

Uma aplicação prática do aquecimento de betume por microondas que convém ser citada é um estudo para sua utilização especificamente em reparos de estradas pavimentadas com excelentes resultados. ${ }^{(9)}$

Além dos rejeitos radioativos, uma grande variedade de produtos industrializados, fabricados com borrachas, por exemplo, são descartados após o uso ou como sobras de produção.

Esses produtos, quando tratados como descarte, são normalmente incinerados (produzindo energia pelo calor gerado ou sofrendo diminuição de volume), encaminhados a aterros sanitários ou utilizados como carga inerte (previamente passando por processos de moagem e pulverização para serem adicionados à matéria-prima para produção de outros artefatos, ou mesmo no próprio processo que os originou com perdas de propriedades físicas e químicas).

Como esses tipos de materiais possuem degradação biológica média da ordem de 400 anos, seu reaproveitamento é de extrema importância na preservação dos recursos naturais. Dessa maneira, a sua utilização na imobilização de rejeitos radioativos em matrizes betuminosas pode ser uma alternativa para contribuir com a redução do volume de lixo e com a diminuição da poluição do ar e da água, além de proporcionar um reforço na estrutura da matriz.

Normalmente, após a conclusão do processo de mistura dos componentes, as matrizes de imobilização são colocadas em tanques de concreto ou rocha, isto é, sítios de rejeitos radioativos permanentes ou temporários, até que ocorra seu decaimento total. Qualquer método proposto para a imobilização de rejeitos radioativos deve atender às necessidades de armazenagem e transporte e reduzir 
a mobilidade e os riscos de intrusão de radionuclídeos na natureza, mesmo que em quantidades mínimas, com o objetivo principal de garantir a máxima proteção ao ser humano e ao meio ambiente. ${ }^{(10,11)}$

\subsection{Fundamentos teóricos}

\subsubsection{Polímeros}

Materiais poliméricos têm sido objetos de estudos para a imobilização de rejeitos radioativos, pois suas características mostram muitas vantagens de uso nessa área.

Genericamente, polímeros são macromoléculas compostas por milhares de unidades de repetição (meros) unidas por ligação covalente. A matéria-prima para a produção de um polímero é denominada monômero, que é uma molécula composta por uma unidade de repetição. Os plásticos, borrachas e fibras, respectivamente, termoplásticos, elastômeros e termofixos, são as grandes classes em que os polímeros se subdividem e cuja definição depende do tipo de monômero, da ligação covalente e do número de meros de cada cadeia. ${ }^{(12)}$

Os termoplásticos são polímeros que sob ação de temperatura e pressão, fundem e podem fluir para dentro dos moldes, assumindo sua forma ao resfriar. Novas aplicações de temperatura e pressão produzem o mesmo efeito de fundir e fluir, isto é, podem ser reciclados. Exemplos: polipropileno (PP), poliestireno (PS) e policloreto de vinila (PVC). ${ }^{(12)}$

Os termofixos são plásticos que com o aquecimento amolecem uma vez, sofrem o processo de cura e tornam-se rígidos. Os materiais termofixos representam $20 \%$ dos plásticos consumidos no Brasil e uma vez conformados, não se consegue mais reprocessá-los, impossibilitando sua reciclagem. São insolúveis e infusíveis; suas propriedades mecânicas não são influenciadas pelo calor, desde que as temperaturas estejam abaixo da temperatura de transição vítrea $\operatorname{Tg}^{(12,13,14)}$

Na FIG. 1, estão representadas as etapas do ciclo dos polímeros desde a sua geração, produção de artefatos, ponto de reciclagem até o momento do descarte final. 


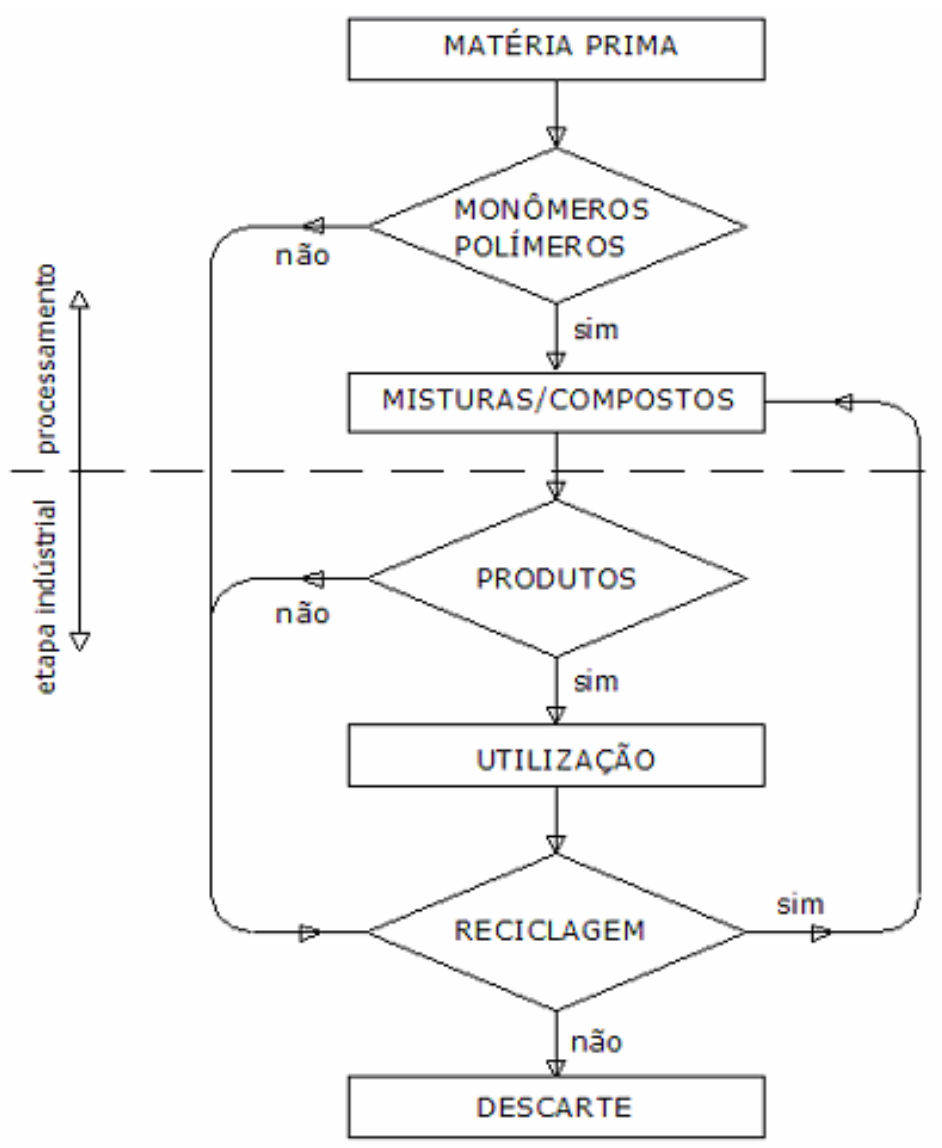

FIGURA 1: Representação esquemática do ciclo dos polímeros, adaptada de ${ }^{(13)}$

\subsubsection{Borrachas}

Conhecida desde a Antiguidade, quando era utilizada para tampar vasilhames ou colar documentos, a resina natural (látex), posteriormente denominada borracha pela capacidade de apagar marcas de lápis, tinha restritas aplicações.

Somente após a descoberta da vulcanização por Charles Goodyear em 1839, por meio de um processo químico com enxofre (principal agente na formação de ligações cruzadas), foram conferidas à borracha características, como elasticidade, ausência de pegajosidade e durabilidade.

Natural ou sintética, a borracha pode ser estendida diversas vezes, sem sofrer danos estruturais, retornando às dimensões originais. Situada em uma classe intermediária entre o termoplástico e o termofixo, após a vulcanização, é difícil alterar seu estado físico ${ }^{(12)}$, onerando os procedimentos para sua reciclagem. 


\subsubsection{Betume}

Desde os primórdios da civilização, há registros e indícios da aplicação de asfalto na pavimentação de ruas ou na impermeabilização de jardins, aquedutos, terraços, piscinas e telhados da Antiguidade, além do uso bélico na forma de bolas de fogo atiradas por catapultas.

As principais qualidades do asfalto que permitem essas aplicações são: a adesividade com os agregados, impermeabilidade, durabilidade das misturas, manutenção de suas propriedades por longo tempo e facilidade de aplicação. ${ }^{(15)}$

De origem natural ou pirogênica, os asfaltos são materiais aglutinantes de cor escura e consistência variável cujo constituinte mais importante é o betume. Encontrados na natureza, são processados em destilação fracionada do óleo cru e disponibilizados como destilados (parcela mais pesada da produção de óleo cru de asfalto), oxidados (obtidos com a injeção de bolhas de ar entre $200^{\circ}$ e $260^{\circ} \mathrm{C}$ ) ou emulsificados (obtidos pela adição de soluções aquosas aniônicas, catiônicas ou não iônicas para destilar).

O betume, por sua vez, é composto por uma ampla variedade de hidrocarbonetos não voláteis de elevada massa molecular, que têm o carbono e o hidrogênio como principais elementos presentes na sua constituição, seguidos de enxofre, nitrogênio e oxigênio. É um material termoplástico, orgânico, semi-sólido ou sólido à temperatura ambiente, de baixa condutividade térmica $\mathrm{e}$ completamente solúvel em bissulfeto de carbono $\left(\mathrm{CS}_{2}\right){ }^{(5,16)}$

Dependendo do tipo e procedimento da matéria-prima e dos processos de refino utilizados, são obtidos betumes com diferentes proporções de asfaltenos, resinas e óleos, suas três frações básicas e responsáveis pelas variações das propriedades físicas. São denominadas maltenos as partes mais leves do processo de extração e com maiores proporções de óleos e resinas. Os asfaltenos, que são sólidos à temperatura ambiente, demonstram comportamento termoplástico, pois, ao serem aquecidos, amolecem e podem ser conformados, e ao resfriarem, tornam-se sólidos.

O betume, constituinte predominante do asfalto, é um dos materiais poliméricos mais utilizados como agente de solidificação, ou seja, como matriz para confinar rejeito radioativo. 
Seu uso garante resistência à lixiviação para a matriz de imobilização, devido à sua estanqueidade impedir o trânsito indesejável de líquidos e à continuidade do material apresentar baixa ocorrência de poros, fissuras ou outras falhas que permitam a passagem de água e conseqüente careação do material imobilizado, devido à sua alta viscosidade quando abaixo da temperatura de amolecimento. Outras vantagens do uso do betume são: a possibilidade de redução de grandes volumes de sobras, resistência à radiação e ao envelhecimento e a possibilidade de incorporação de rejeitos com variadas propriedades químicas e físicas.

A importância dessas propriedades se relaciona às condições de estocagem e transferência do betume fundido, quando da execução das matrizes de imobilização, às condições operacionais, à compatibilidade com o rejeito e aos requisitos para armazenagem. ${ }^{(2,17)}$ Finalmente, a alta e rápida solubilidade em solventes facilita a limpeza dos equipamentos do processo de betuminização.

Comparados a uma matriz de betume puro, os principais benefícios pretendidos com a adição de polímeros à matriz betuminosa são: a redução da suscetibilidade térmica; aumento da adesividade aos agregados e da vida útil; melhoria da resistência à fadiga e a deformações permanentes; maior resistência ao envelhecimento e ao surgimento de trincas térmicas. ${ }^{(18)}$

O betume, quando fundido, facilita o processo de mistura; ${ }^{(10,19)}$ porém, nos muitos processos de betuminização avaliados, não são todos os tipos de rejeitos que podem ser assim imobilizados devido a fatores, como forma (rejeitos sólidos), composição química desfavorável que ataque a estabilidade ou a qualidade do produto, e também dano de radiação ao material da matriz ${ }^{(5)}$ apesar da sua boa estabilidade às radiações alfa, beta e gama. Dois aspectos adicionais precisam ser considerados: reações de materiais em contato com o betume e a sua possível biodegradação.

Experimentos conduzidos na Inglaterra em 1983 mostraram a influência do tipo de betume no grau de inchação da matriz. Quando um determinado tipo de betume é irradiado com gama, ocorre internamente à matriz tensão mecânica pela formação de gases, cuja liberação é facilitada pelo aparecimento de bolhas ou rachaduras na superfície do bloco.

Posteriormente, na França, esses testes foram reavaliados e foi observado que o surgimento de bolhas e ruptura da superfície era muito mais significativo 
nos modelos do que em escala natural (1:1), principalmente quando se utilizou betume oxidado que não apresentou aumento de volume quando a dose de radiação gama excedeu $2 \times 10^{8} \mathrm{~Gy}$. Para doses inferiores a $10^{6} \mathrm{~Gy}$, o betume puro apresentou melhores propriedades, como ponto de amolecimento e penetração.

Para doses de radiação muito altas, acima de $10^{8} \mathrm{~Gy}$, não só o betume, mas todos os polímeros são transformados em material tecnicamente sem utilização. Para minimizar o efeito da radiação, é desejável que a dose total seja limitada a $10^{7} \mathrm{~Gy}$. A parcela de rejeito para a qual essa limitação não é necessária exclui processos de purificação provenientes de um reator de geração de energia, como filtração, precipitação, resinas de troca iônica e evaporação, os quais resultam em lama, lodo e concentrados. Rejeitos de reatores geradores de energia contêm produtos ativados como ${ }^{60} \mathrm{Co}$ e produtos de fissão como ${ }^{137} \mathrm{Cs}$.

Ao se comparar a limitação de dose possível de ser imobilizada pelo betume, com o limiar de esterilização permanente para o homem (dose absorvida única de cerca de 3,5 Gy a 6Gy nos testículos) e para a mulher (de 2,5Gy a 6Gy), é possível compreender a necessidade de aprimorar cada vez mais as técnicas para impedir a dispersão de rejeitos radioativos no meio ambiente.

Rejeitos líquidos de nível intermediário, oriundos de instalações de reprocessamento de combustível nuclear, podem conter sais (nitrato) com concentração de radiação alfa, beta e gama acima de $4 \mathrm{TBq} / \mathrm{m}^{3}$, tributil fosfato (TBP) e seus produtos de decomposição. A prática comum indica que rejeitos de nível baixo e médio em instalações nucleares de reprocessamento e estabelecimentos de pesquisas podem ser envolvidos em betume pela razão de produzir uma matriz sólida de baixa permeabilidade que pode ser mais facilmente movimentada, transferida, estocada e enviada para a disposição final.

Vantagens podem ser obtidas das reações do betume com materiais que ficam em contato sob condições de armazenagem e disposição, visto que importantes propriedades do betume são afetadas somente próximo ou na superfície do produto e não modificam ou colocam em risco suas funções de cobrir e proteger materiais. A habilidade do betume de resistir a ataques de diferentes soluções químicas sugere que ele pode mostrar boa resistência a soluções aquosas menos agressivas e a vários materiais sólidos que ocorrem na natureza e em repositórios de rejeitos. ${ }^{(5)}$ 


\subsubsection{Resinas de troca iônica}

Uma questão é sempre predominante: a melhoria das condições de imobilização dos resíduos em formas mais estáveis.

As resinas de troca iônica, que são materiais gelatinosos e porosos, portanto muito sensíveis a impurezas sólidas, são consideradas importantes ferramentas em instalações nucleares, pois retiram radionuclídeos, impurezas ou eletrólitos interferentes dispersos no sistema de filtragem da água de refrigeração dos reatores e os retêm em seu interior. Amolecimento de águas, deionização, recuperação de metais, preparação de reagentes, além de produção e purificação de radioisótopos, são outras aplicações comuns para as resinas de troca iônica.

Para utilização de resina de troca iônica em instalações nucleares, devem ser observadas as seguintes funções principais:

- Desmineralizar a água;

- Remover contaminantes radioativos, tais como produtos de corrosão ativados;

- Remover oxigênio do refrigerante no sistema primário do reator;

- Controlar as concentrações dos aditivos na água, tais como inibidor de corrosão e envenenador de nêutrons.

Enquanto as resinas catiônicas são excepcionalmente estáveis e resistem bem a ácidos, hidróxidos, agentes oxidantes e solventes orgânicos, as resinas aniônicas são mais sujeitas à decomposição, que é acentuada em água quente. São essas características que permitem definir um ciclo de regeneração.

A maioria das resinas de troca iônica encontradas comercialmente são resinas orgânicas sintéticas, formadas por uma cadeia de hidrocarbonetos, geralmente poliestireno linear. O divinil-benzeno (DVB) reticula a matriz como função de sua concentração. O aumento da porcentagem de DVB diminui a solubilidade, a porosidade e o inchamento, mas aumenta sua rigidez. ${ }^{(20,21)}$

Durante cada ciclo de operação das resinas, ocorrem duas fases distintas: a sorpção, que compreende a "carga, saturação e carregamento", e a lavagem, com as etapas de "solução, vazão e lavagem". (21)

Como menos de $100 \%$ da resina é regenerada a cada tratamento, devido às reações agressivas de passagem pelas colunas de resinas catiônica e aniônica de soluções de ácido sulfúrico e soda cáustica, respectivamente, ao final de 
alguns ciclos, o poder de troca iônica deixa de ocorrer na quantidade desejada. Assim, a resina exaurida passa a ser considerada como rejeito radioativo passível de imobilização.

$\mathrm{Na}$ FIG. 2, está esquematizado um reator nuclear gerador de energia elétrica, enfatizando a posição dos filtros no circuito primário de onde são retiradas as resinas de troca iônica quando exauridas.

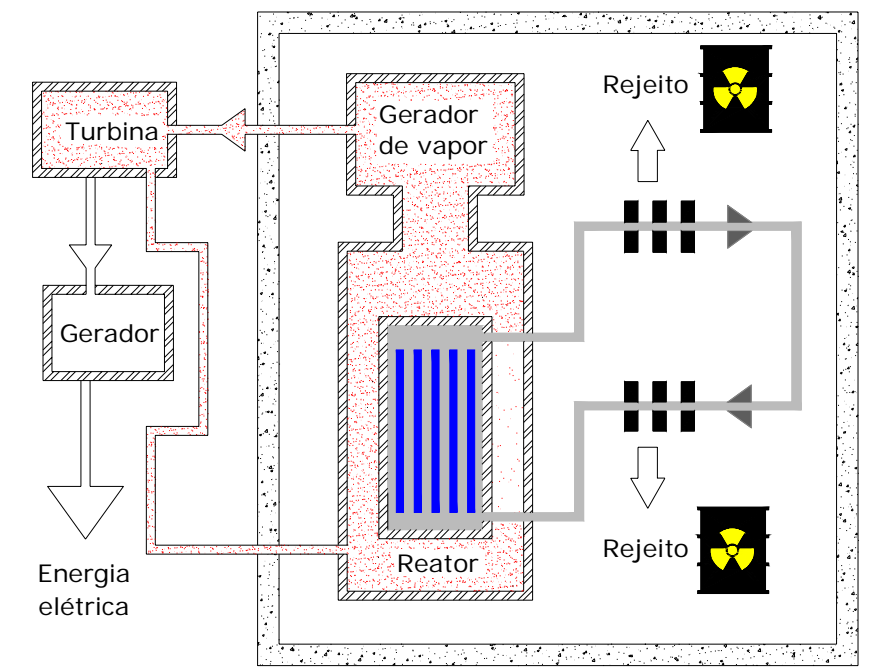

FIGURA 2: Posição dos filtros no circuito primário de um reator nuclear

Na FIG. 3, são mostradas as colunas que alojam as resinas de troca iônica com blindagem e as tubulações externas para manobras do Reator IEA-R1 localizado no Instituto de Pesquisas Energéticas e Nucleares (IPEN-CNEN/SP).
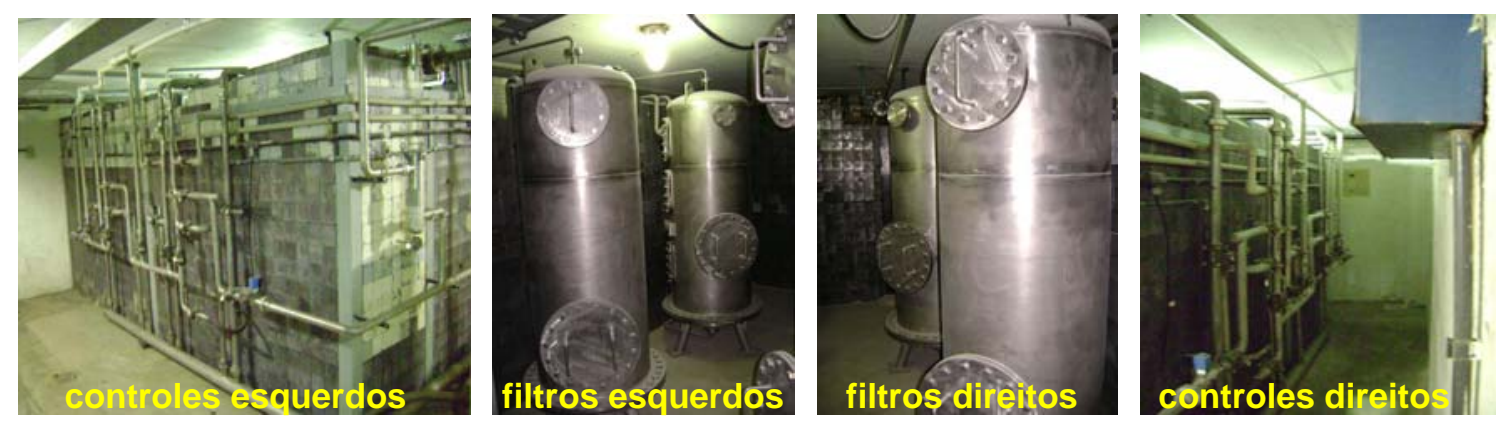

FIGURA 3: Filtros com resina de troca iônica do Reator IEA-R1 do IPEN

\subsubsection{Magnetita}

A magnetita $\left(\mathrm{Fe}_{3} \mathrm{O}_{4}\right)$ é constituinte comum de rochas magmáticas, mas também pode ser encontrada em rochas metamórficas. Apresenta brilho metálico, 
elevada dureza, traço preto e caráter fortemente magnético, comportando-se como um ímã natural. Dentre as aplicações mais usuais, pode ser citado seu uso como lastro na composição de concreto de alta densidade, em banhos para isolação térmica e na blindagem de raios- $X$.

Por ser quimicamente estável, infusível, armazenadora de calor, ${ }^{(22)} \mathrm{e}$ principalmente por ser um excelente absorvedor de energia de microondas ${ }^{(9)}$, foi possível experimentar sua utilização na fase de fusão do betume neste trabalho.

Conceitualmente, quanto maior for a constante dielétrica $(\varepsilon)$ do material, maior quantidade de energia poderá ser por ele armazenada e mais rapidamente ocorrerá a elevação da temperatura sob ação da energia de microondas, onde a temperatura é a medida do grau de agitação das moléculas de um corpo, e o calor é a energia térmica em trânsito, isto é, a energia transferida de um corpo para outro quando existe diferença de temperatura entre eles.

\subsubsection{Técnicas de imobilização de rejeitos radioativos}

Imobilizar rejeitos significa evitar ou restringir a dispersão não intencional de radionuclídeos no meio ambiente a partir de um local de estocagem ou disposição. Essa imobilização envolve o acondicionamento em unidades discretas durante sua armazenagem ou disposição final, o que facilita o transporte e a inspeção com a racionalização do uso de sistemas de controle e segurança, manutenção, monitoramento e intervenção humana. ${ }^{(20,23)}$

Para o gerenciamento, os rejeitos radioativos provêm de dois tipos de instalações:

1. Instalações nucleares, que abrangem todas as fases do ciclo do combustível: mineração, beneficiamento, conversão, enriquecimento, reconversão, produção das pastilhas e elemento combustível (uso e armazenagem final);

2. Instalações radioativas, que envolvem clínicas, hospitais, indústrias, universidades, centros de pesquisas, etc.

Três são os princípios básicos de radioproteção:

1. Princípio da justificação: Toda prática que envolve radiação ou exposição deve ser justificada em relação a práticas alternativas e produzir um lucro líquido positivo para a sociedade. 
2. Princípio da otimização: $A$ exposição dos indivíduos à radiação, bem como a dose coletiva resultante da presença de rejeitos radioativos, deve ser tão reduzida quanto razoavelmente exeqüível (ALARA), levando-se em conta fatores sociais e econômicos.

3. Princípio da limitação de doses: As doses individuais dos indivíduos ocupacionalmente expostos e dos indivíduos do público não devem exceder os limites anuais de dose equivalente estabelecidos nas normas de proteção radiológica, (exceto: radiação de fundo, diagnóstico médico e tratamento médico). ${ }^{(24)}$

As doses referidas são provenientes de materiais emissores de radiação ionizante gerados em instalações nucleares ou radioativas.

Na FIG. 4, foi estilizado o poder de penetração das diferentes formas de emissões com diferentes energias, produzindo assim diferentes efeitos nos seres vivos. ${ }^{(25)}$

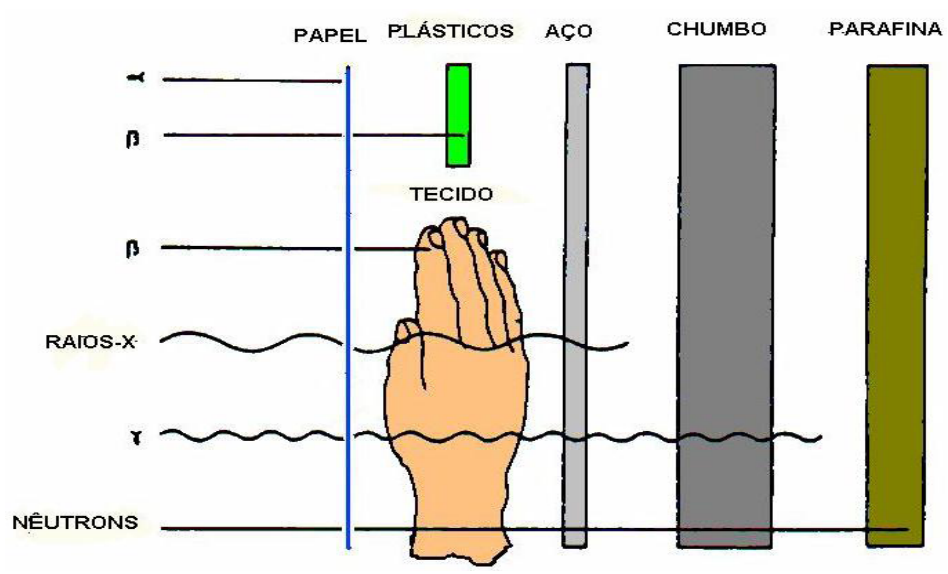

FIGURA 4: Representação do poder de penetração de emissões $\alpha, \beta, \gamma, X e$ nêutrons

$\mathrm{Na}$ FIG. 5, estão representadas as etapas do gerenciamento de rejeitos radioativos desde a sua geração, reuso, disposição final ou liberação de efluentes para o meio ambiente. 
Rejeitos e materiais

radiativos

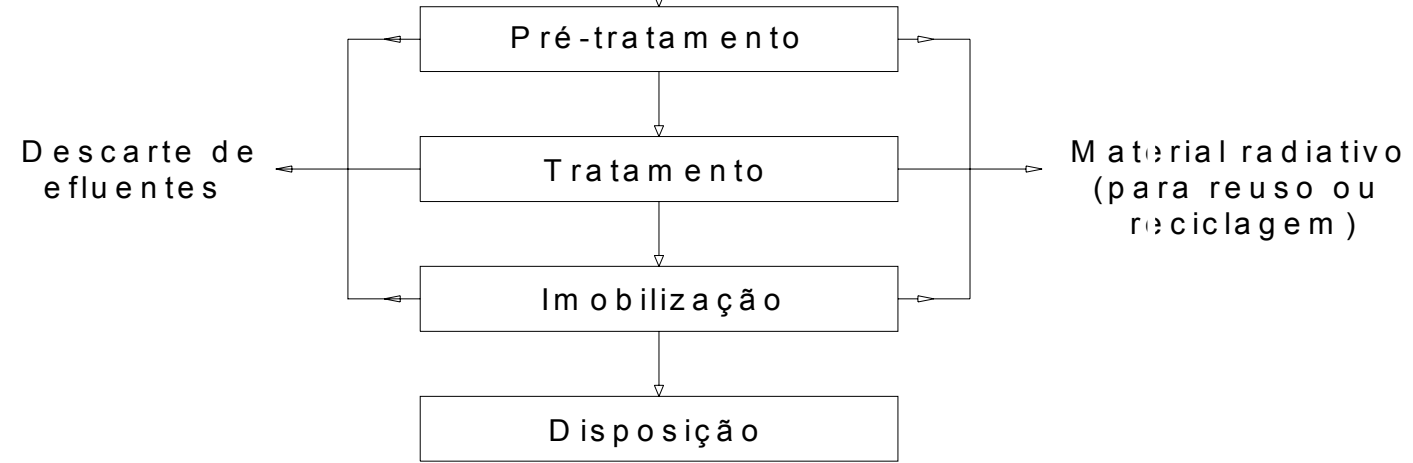

FIGURA 5: Diagrama simplificado do gerenciamento de rejeitos radioativos ${ }^{(4)}$

Tendo sua origem a partir dos mais variados processos, os rejeitos radioativos existem nos estados: sólido, líquido e gasoso.

Para melhor segregação desses materiais, conforme a atividade apresentada, eles são classificados como: rejeitos de alto nível (HLW, high level waste): produtos do reprocessamento dos elementos combustíveis usados em reatores; rejeitos de nível intermediário (ILW, intermediate level waste): resinas exauridas e filtros retentores de partículas radioativas, os quais são imobilizados em matriz sólida por cimentação ou betuminização; rejeitos de baixo nível (LLW, low level waste): luvas, sapatilhas, máscaras e ferramentas contaminadas, que são armazenadas em tambores até não apresentarem riscos para reuso ou descarte. $^{(26,27)}$

Dependendo do tempo de decaimento, são classificados como de meia vida $(1 / 2$ vida) curta, média ou longa.

Para cada combinação dos parâmetros desses rejeitos (estado físico, nível de atividade e tempo de $1 / 2$ vida), existem métodos adequados à sua imobilização.

A imobilização e armazenamento de rejeitos durante longo tempo devem ser feitos em embalagens física e quimicamente estáveis que devem ser mantidas de forma a minimizar a necessidade de controle, sistemas de segurança, manutenção, monitoramento, ventilação e intervenção humana. ${ }^{(23)}$

Os rejeitos radioativos gerados ao longo de mais de quatro décadas do uso da energia nuclear no Brasil se encontram armazenados em instalações pertencentes ou supervisionadas pela Comissão Nacional de Energia Nuclear (CNEN) e representam um volume superior a $15400 \mathrm{~m}^{3}$ recolhidos de todo o país. 
Seu gerenciamento implica uma série de ações que incluem a coleta no local de produção, a segregação pelo tipo de rejeito, o transporte para a área de tratamento e para o armazenamento ou disposição final. ${ }^{(26)}$

\subsubsection{Vitrificação}

A vitrificação pode ser compreendida como sendo a conversão de materiais em vidro ou substâncias semelhantes e, apesar de manter inalterado o nível de radioatividade, facilita a movimentação da matriz de imobilização.

A vitrificação é conceitualmente interessante por causa da potencial durabilidade do produto e da flexibilidade do processo no tratamento de uma ampla variedade de rejeitos e contaminantes. Essas características tornam a vitrificação o principal processo de tratamento para rejeitos radioativos de alto nível e uma alternativa atrativa para rejeitos radioativos de baixo nível. Esse processo pode ser aplicado dentro ou fora das instalações.

Pesquisas com vidro borosilicato, para imobilização de rejeito nuclear, têm indicado que a lixiviação varia muito pouco quando a carga de rejeito aumenta em até $50 \%$ em peso. Assim, a quantidade de rejeito imobilizado com vidro borosilicato pode não ser limitada pela durabilidade do produto, mas pelas considerações de processamento. ${ }^{(11)}$

\subsubsection{Supercompactação}

A supercompactação proporciona redução de volume da ordem de 16:1, bem como um certo grau de estabilização de rejeitos heterogêneos.

$\mathrm{Na}$ compactação de materiais físseis, é importante que na análise de segurança, seja considerado o aumento de refletividade dos plásticos nas matrizes do rejeito, bem como as mudanças de geometria.

Para agrupar vários containeres em um, é importante considerar o limite da liberação de gás gerado e de saída de calor. ${ }^{(7)}$ 


\subsubsection{Cimentação}

O cimento, composto basicamente de cálcio, silicatos, alumínio e óxidos de ferro, foi um dos primeiros materiais utilizados na imobilização de rejeitos. Técnicas de aplicação baseadas nas atividades da Engenharia Civil permitem afirmar que sua estabilidade estrutural é conveniente para disposição e manutenção da integridade do sistema.

O cimento tem sido usado com ou sem aditivos, que melhoram a compatibilidade cimento/agregados, reduzem o fator água/cimento e até impedem o crescimento de bactérias causadoras de gases internos do bloco. ${ }^{(22)}$

O cimento Portland é um material barato e comum. Sua adição melhora consideravelmente as propriedades físicas e químicas da mistura e diminui a taxa de lixiviação, mas o equipamento precisa de cuidados especiais, pois será contaminado durante a operação. Portanto, o equipamento também deverá ser considerado, aumentando o capital operacional e os custos de manutenção do sistema se o processo de imobilização escolhido for o de misturar agitando rejeitos, cimentos e o tambor, ou colocar o misturador dentro do tambor para se efetuar a mistura.

No caso da cimentação de resina de troca iônica, o inconveniente passa a ser seu inchamento na presença de água, o que pode levar a um aumento das pressões internas do bloco, ocasionando o aparecimento de fissuras e trincas que exporiam o material imobilizado. ${ }^{(11)}$ Com fatores de inchamento das resinas de $1,4 \mathrm{~mL} / \mathrm{g}$ e $1,2 \mathrm{~mL} / \mathrm{g}$ para aniônica e catiônica, respectivamente, as cargas máximas incorporadas foram $15 \%$ em massa. ${ }^{(20)}$

O fator água/cimento também depende da umidade do rejeito nas suas proporções finais para evitar tanto o inchamento da resina, quanto o surgimento da nata de cimento na superfície do bloco, o que diminui a resistência e a impermeabilidade do conjunto final. ${ }^{(10)}$

\subsubsection{Fixação com polímeros}

Termoplásticos também podem ser usados para imobilizar rejeitos radioativos pelo processo chamado microencapsulamento termoplástico. $\mathrm{O}$ 
termoplástico mais usado é o betume, mas o polietileno e o polipropileno também podem ser empregados.

Nessa técnica, é necessário aquecer o material base para misturá-lo com o rejeito. São utilizados os mesmos tipos de containeres que na cimentação, porque a matriz encapsulada contém em torno de $50 \%$ em peso do rejeito sólido.

Cimento sulfúrico modificado, também chamado de cimento polimérico sulfúrico, é uma alternativa para o cimento hidráulico e o betume na solidificação de rejeitos radioativos. Esse tipo de cimento começa a fundir em $110^{\circ} \mathrm{C}$ e, como o betume, precisa ser misturado ao rejeito seco e refrigerado para formar uma matriz sólida. Ele é estável e resistente a ambientes extremamente agressivos e a ataques pela maioria dos ácidos corrosivos e sais. Não são necessárias reações químicas para a sua solidificação, sendo sua resistência mecânica o dobro da do cimento hidráulico, e a resistência total é atingida em horas contra semanas necessárias para o cimento hidráulico.

O cimento sulfúrico modificado tem sido usado na solidificação de rejeitos de baixo nível de radioatividade contendo sais de sulfato de sódio, sais de ácido bórico e cinzas de incinerador. A vantagem operacional é não necessitar de esvaziamento ou limpeza do equipamento após concluir o escoamento da mistura para o tambor. ${ }^{(11)}$

A mistura compreendida de polímero, catalisador e rejeito forma uma esponja porosa que retém este último. As características do polímero definem se a matriz final será sólida ou flexível, bem como indicam a necessidade prévia de secar ou não o material a ser imobilizado. ${ }^{(7,11)}$

Reações poliméricas ocorrem a temperaturas entre $20^{\circ} \mathrm{C}$ e $60^{\circ} \mathrm{C}$ com o uso de catalisadores, ou a temperaturas maiores quando se pretende utilizar menor tempo de reação. Na FIG 6, é mostrado um esquema de incorporação de resina de troca iônica em polímeros. ${ }^{(7)}$ 


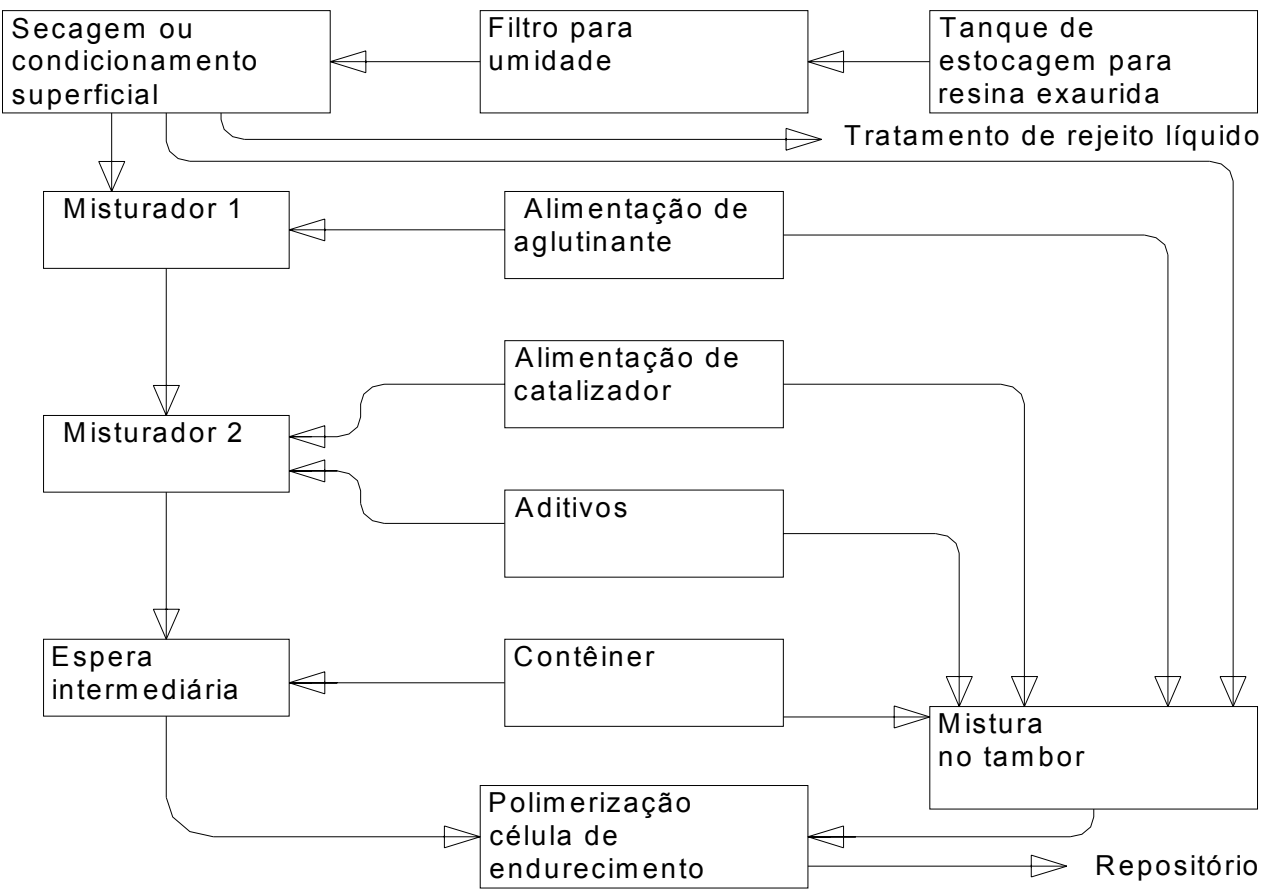

FIGURA 6: Esquema para encapsulamento de resina exaurida de troca iônica em polímeros

\subsubsection{Betuminização com extrusora}

A técnica de imobilização de rejeitos radioativos com betume tem sido utilizada desde 1960 por diversos países, como França, Bélgica, Canadá, e mais recentemente, Brasil. ${ }^{(17)}$

O processo por extrusão pode ser feito com ou sem evaporação. O primeiro consiste em misturar rejeitos líquidos ou pastas com betume fundido, em operação de alimentação contínua e temperatura de $200^{\circ} \mathrm{C}$, e que haja um sistema de filtração de gases e vapores. Caso ocorra uma pequena variação da temperatura, incrustações poderão ocorrer, causando danos às roscas do equipamento. Dessa maneira, toda a seqüência deverá ser criteriosamente monitorada por meio de instrumentos adequados e de pessoas habilitadas. $O$ segundo requer que o rejeito seja pré-aquecido a $130^{\circ} \mathrm{C}$, também com alimentação contínua. Além disso, não necessita de equipe especializada para operação do equipamento. ${ }^{(11)}$

$\mathrm{Na}$ betuminização com extrusora, o pré-aquecimento, a pesagem e a mistura do betume com o rejeito se processam automaticamente. A mistura é feita por meio de um ou dois parafusos rotativos horizontais que amassam, misturam e 
transportam a massa rejeito/betume até o ponto de descarga. Câmaras de óleo estrategicamente localizadas são mantidas aquecidas durante todo o processo para manter baixa a viscosidade da mistura e propiciar a evaporação da água livre do mecanismo alimentador. O processo se encerra com o lançamento da massa fundida em tambores metálicos, sendo que ao final de cada etapa de trabalho, todo o equipamento deve ser limpo por meio da passagem de betume puro, até que esse material seja expelido sem traços de radiação.

O fluxograma simplificado desse processo é mostrado na FIG. $7 .^{(17)}$

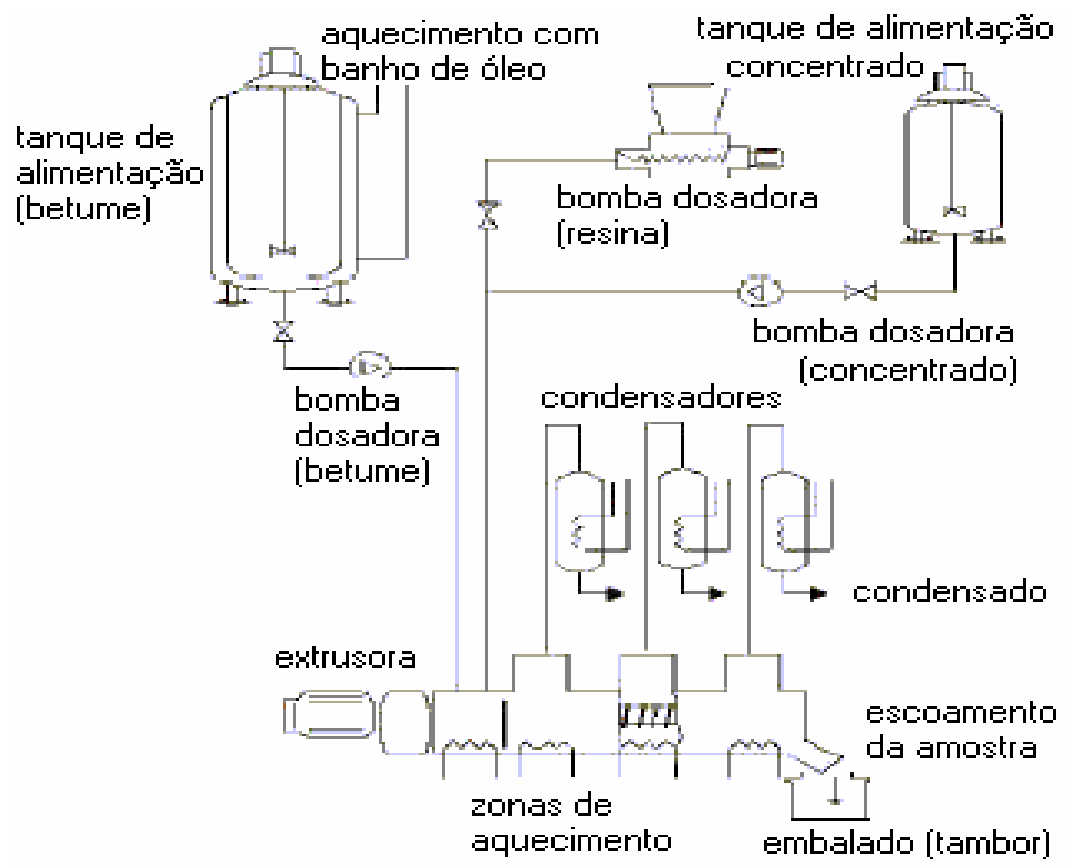

FIGURA 7: Fluxograma simplificado de um processo com extrusora

\subsubsection{Betuminização com microondas}

As microondas foram inicialmente desenvolvidas para ampliar o intervalo das freqüências utilizadas em telecomunicações (radares), e sua pesquisa levou à descoberta acidental do efeito de aquecimento. São radiações eletromagnéticas não-ionizantes, mas podem ou não causar efeitos térmicos.

As microondas, conforme pode ser observado na FIG. 8, estão posicionadas entre as freqüências de ondas de rádio (RF) e infravermelho (IR), no intervalo de $300 \mathrm{MHz}$ a $300 \mathrm{GHz}$. Neste trecho, as freqüências de trabalho de $915 \mathrm{MHz}$, $2.450 \mathrm{MHz}$ (microondas caseiro, mais utilizado em pesquisas), $5.800 \mathrm{MHz}$ e 
22.125MHz foram aceitas internacionalmente para uso em instalações científicas e industriais de microondas. $(28,29,30)$

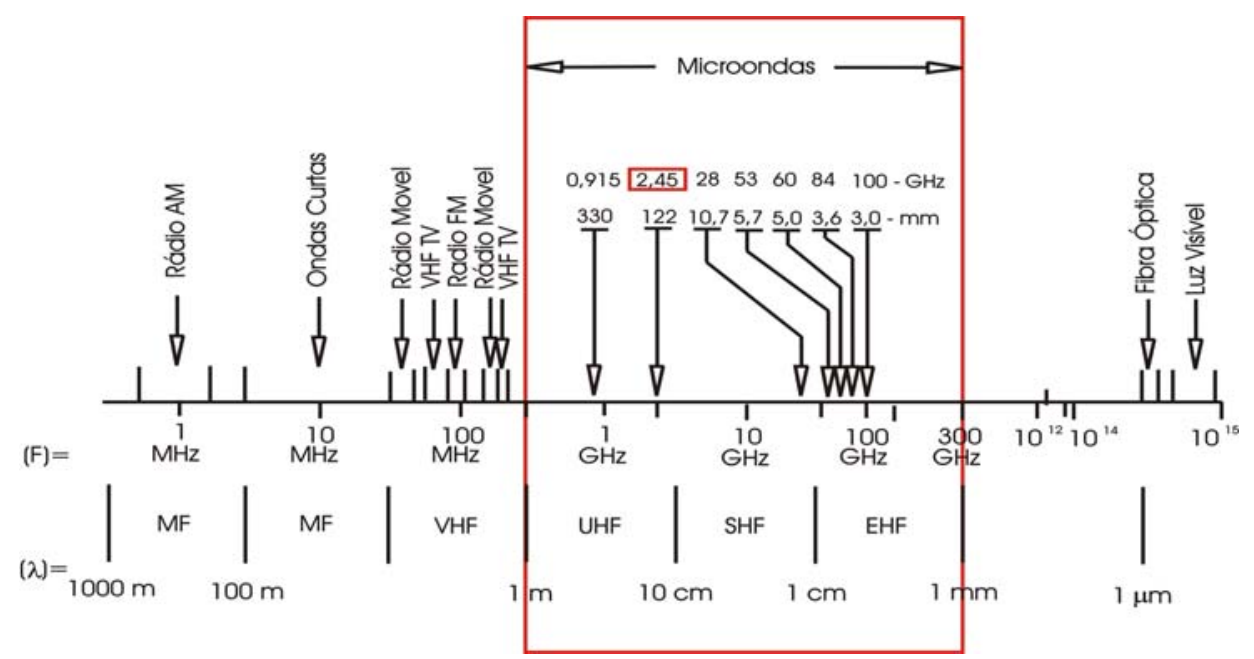

FIGURA 8: Espectro eletromagnético indicando freqüências de ondas ${ }^{(29)}$

O mecanismo de aquecimento provocado pelas microondas é aquele no qual a energia é absorvida pela matéria e transformada em energia, sem alterar a estrutura molecular, porém modificando as propriedades físicas do material. Isso permite que se atinjam altas temperaturas em um curto espaço de tempo. No caso do forno doméstico, a energia é distribuída aleatoriamente na cavidade como resultado de múltiplas reflexões nas paredes do forno. ${ }^{(30,31,32)}$

Nesse caso, as moléculas que apresentam momento dipolo (polares) tendem a se orientar com o campo elétrico. A direção do campo varia continuamente em fração de segundos, o que ocasiona uma perda angular por fricção e, por conseqüência, aquecimento do material (FIG. 9).

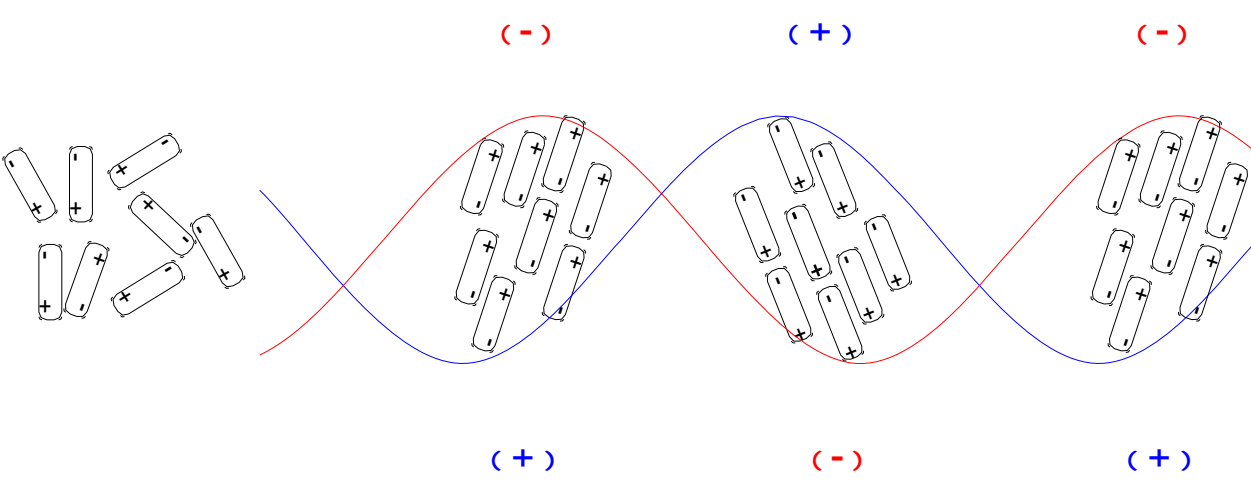


Os materiais reagem diferentemente diante da energia de microondas. Nesse sentido, eles são classificados como: condutores, isolantes e dielétricos (FIG.10).

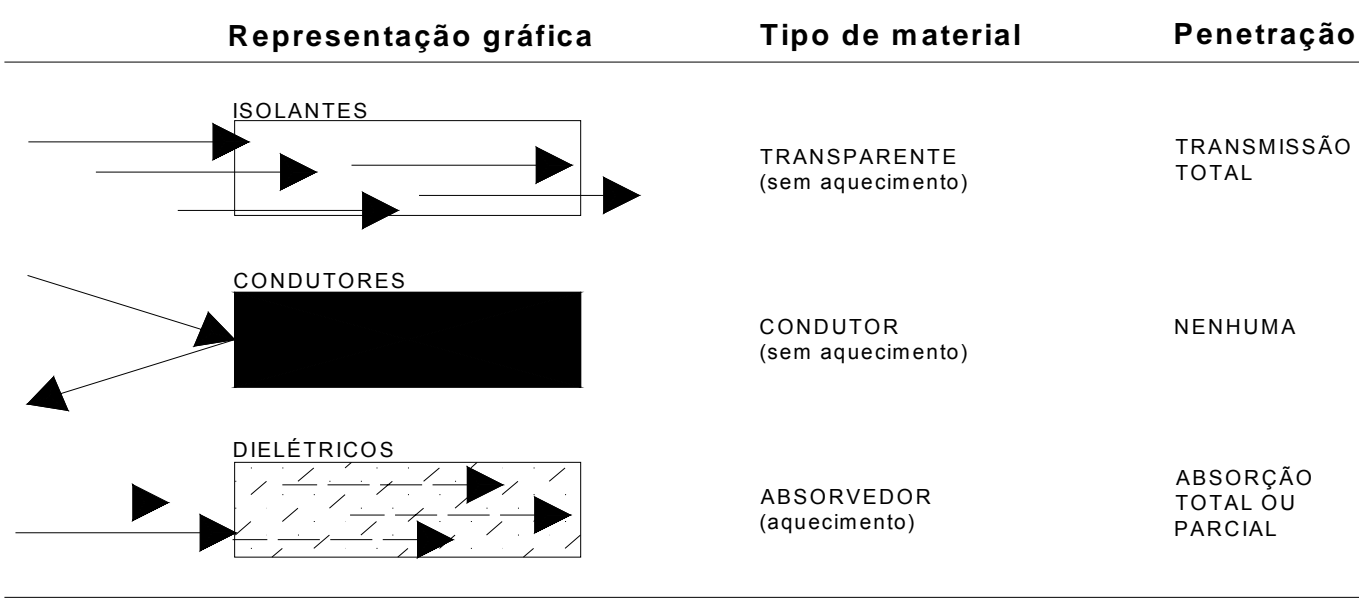

FIGURA 10: Reação dos materiais sob a ação de radiação eletromagnética ${ }^{(2)}$

A família dos condutores (materiais opacos) é basicamente formada pelos metais que refletem as microondas (assim como um espelho reflete a luz), não havendo penetração dessas ondas.

Os isolantes transmitem as microondas com pouco, ou até mesmo nenhum efeito de aquecimento, semelhante à passagem da luz por um vidro (são os plásticos, vidros e cerâmicas).

Os dielétricos são a maioria dos materiais e têm propriedades entre os isolantes e os condutores (como água, gorduras, óxidos e outros). As microondas penetram nesses materiais como nos isolantes, mas ao contrário destes, absorvem energia. Essa absorção resulta em um aquecimento dielétrico.

Algumas vantagens desse processo em relação ao de betuminização com extrusora são:

- Maior rapidez, seletividade, mais uniformidade e se inicia de dentro para fora do material;

- Transferência de energia em vez de calor;

- Não necessidade de descontaminar o equipamento ao final de cada etapa de trabalho;

- Rapidez de início e parada do equipamento;

- Maior nível de segurança e automação; 
- Economia de energia elétrica;

- Utilização de espaços menores para instalação do equipamento. 


\section{REVISÃO DE LITERATURA}

\subsection{Tecnologia de aquecimento por microondas}

Várias pesquisas foram desenvolvidas utilizando a tecnologia de aquecimento com microondas. A seguir, serão citados alguns trabalhos realizados.

Thostenson e Chou (1999) fizeram uma revisão dos fundamentos de teoria eletromagnética, resposta dielétrica e aplicações de aquecimento por microondas para o processamento de materiais, como cerâmicas e polímeros, destacando seus comportamentos quando submetidos a esse tipo de processo. Um dos maiores efeitos de microondas foi a aceleração da cinética de cura em resinas termofixas. $^{(33)}$

Jeon e Kim (2000) estudaram os efeitos da radiação de microondas na difusão de algumas moléculas orgânicas pequenas em PE (polietileno), PVC (poli cloreto de vinila) e borracha de silicone, usando o método de ganho de peso. ${ }^{(34)}$

El Harfi et al. (2000) estudaram a pirólise de xisto de óleo na unidade de Tarfaya (Marrocos), uma instalação especialmente adaptada para irradiação com microondas. Os objetivos do trabalho foram: melhorar o rendimento e a qualidade do óleo; entender os mecanismos físico-químicos envolvidos na pirólise; comparar os resultados obtidos com aqueles da pirólise convencional. O método consistia em colocar o resíduo de óleo dentro de uma câmara e, com aplicação de microondas, gerar temperatura suficiente para converter a água em vapor e separá-la do resíduo. ${ }^{(35)}$

Jones et al. (2002) revisaram aplicações do aquecimento por microondas em engenharia ambiental, incluindo as áreas de recuperação de solo contaminado, tratamento de rejeitos, processamento de minerais, regeneração de carbono ativado, tratamento de compostos orgânicos voláteis e reciclagem de pneus de borracha. Neste último caso, o processamento de restos de pneus pode proporcionar a reutilização do material de borracha (obtendo-se produtos similares àqueles iniciais), recuperação de materiais e energia. Como na fabricação de borracha é empregado o processo de vulcanização, pneus usados não são reutilizados diretamente, sendo necessário tratar a borracha com o 
processo de devulcanização por regeneração e reuso como material virgem. A presença de compostos polares é um pré-requisito para que a devulcanização por microondas seja eficaz. Um exemplo é o elastômero vulcanizado de enxofre que contém tais grupos polares e, portanto, é conveniente para esse método. ${ }^{(36)}$

Bjorndalen e Islam (2004) discutiram a recuperação de óleo em tanques horizontais, o que traz um benefício incontestável à indústria de petróleo. Nesse trabalho, pesquisaram a possibilidade de usar as microondas para remover esses precipitados remotamente, sem necessitar de operações agressivas e dispendiosas. Os resultados incluíram temperatura e viscosidade para várias concentrações de óleo bruto, asfaltos e cera parafínica sob diferentes tempos de exposição.

A maior concentração do asfalto estava no óleo bruto e o maior aumento da temperatura seria sob irradiação com microondas. Quanto maior a concentração de asfalto, menor a viscosidade sob ação das microondas. Isso se atribui à reorientação das moléculas combinadas com a quebra de algumas partículas do asfalto. ${ }^{(37)}$

Krishnan et al. (2005) concentraram sua atenção no comportamento mecânico do modelo de asfalto para a escala de temperatura na qual o asfalto fosse mais elástico. Apesar do extenso número de publicações a respeito da influência da temperatura na reologia do asfalto, continuam incompletas as informações necessárias para se fazer uma suposição razoável a respeito do comportamento dinâmico e da termodinâmica do asfalto liso. Esse conhecimento facilitará o entendimento dos processos de envelhecimento, cura, misturas de concreto asfáltico, etc.

Os autores concluíram que, sem nenhuma originalidade, o asfalto é uma mistura complexa de diferentes componentes químicos, e as diferentes manifestações do seu comportamento mecânico dependem das relativas proporções de cada um desses componentes. ${ }^{(38)}$

García-Morales et al. (2005) estudaram os efeitos da adição de rejeitos poliméricos na reologia do betume modificado. EVA (etileno vinil acetato) e EVA/PEBD (polietileno de baixa densidade) combinados, fragmentos de borracha de pneu e ABS (acrilonitrila-butadieno-estireno) foram experimentados como agentes de modificação de betume na construção de pavimentos. Esses materiais foram caracterizados por microscopia óptica, calorimetria e outros testes 
especificamente desenvolvidos para esse propósito, numa larga escala de temperatura. Para as condições atuais de trânsito, o betume puro não resulta como um material adequado, mas a adição de material polimérico proporcionou um comportamento aumentado ao betume, evitando sua deformação pela alta temperatura de serviço. ${ }^{(18)}$

David Reed et al. (1992) informaram que em Los Angeles (Califórnia), 150 milhas de vias públicas foram recuperadas com 800.000 toneladas de asfalto misturado a quente (HMA) com 250.000 toneladas de asfalto recuperado de pavimento (RAP), na proporção de 85:15 em peso, respectivamente.

O método consistiu no pré-aquecimento dos materiais no transportador para o misturador, de forma convencional. Essa mistura passou por um túnel onde um gerador de microondas a aqueceu. Os agregados, sendo polares, foram aquecidos pelas microondas, e lentamente o calor foi transferido ao cimento asfáltico, sem causar sua queima. O resultado foi um HMA, que poderia ser armazenado em silos, pronto para uso.

A vantagem do aquecimento com microondas é a obtenção de uma melhor adesão do asfalto com os agregados, o que proporciona uma melhor resistência à água. ${ }^{(39)}$

\subsection{Imobilização de Rejeitos Radioativos}

Nos últimos anos, têm sido realizados diversos estudos sobre os efeitos da radiação nos seres humanos e no meio ambiente. Muitos esforços têm sido dirigidos para desenvolver métodos e materiais mais eficientes e eficazes para minimizar esses efeitos. Pesquisadores têm relatado o uso de materiais que podem ser capazes de estocar rejeitos nucleares por milhares de anos, e ainda assim resistirem a vazamentos e impedirem os danos causados pela radiação.

A seleção de um bom sistema deve considerar o tipo, estabilidade físicoquímica, volume de rejeito a ser tratado, equipamento, facilidade de operação e custos de manutenção, sempre levando em consideração a resistência à lixiviação, de tal forma que a liberação de radionuclídeos seja a mais lenta possível, mesmo em contato com fluxos contínuos de gases ou líquidos ${ }^{(7)}$.

Diversas técnicas de processamento e materiais têm sido exploradas para imobilização de rejeitos radioativos. A seguir, serão citadas algumas delas. 
Menezes et al. (2002) relataram a imobilização em matrizes de cimento. Como exemplo, foi citado o cimento Portland, que não requer tratamentos térmicos para transformar resíduos nocivos em inertes, imersos em uma matriz estável. O produto final era resistente a agentes ambientais agressivos e foi aprovado nos ensaios de resistência à lixiviação, podendo ser depositado em aterros, de forma segura. Entretanto, esse processo tem sofrido uma crescente oposição em muitos países da comunidade européia, em virtude da estabilidade desses materiais não estar definitivamente comprovada, e também porque o volume da mistura de cimento é bem maior do que o do resíduo. Isso normalmente reduz a capacidade dos aterros.

Os autores ainda citaram muitos estudos dedicados ao desenvolvimento de materiais cerâmicos capazes de incorporar resíduos radioativos, na forma vítrea ou cristalina, sempre com um enfoque na capacidade de imobilização desses resíduos e na estabilidade desses materiais ao longo do tempo, uma vez que são submetidos a uma fonte de radiação, o que decresce a sua durabilidade e estabilidade.

Uma outra abordagem citada nesse trabalho foi a utilização de vidro para a imobilização de resíduos nocivos à saúde, visto que a temperatura de operação destrói a matéria orgânica. O vidro imobiliza metais pesados, é uma matriz comprovadamente estável, com consistente redução do volume e é capaz de converter composições químicas complexas em materiais usuais de grande aplicação no mercado. Essa tecnologia se baseia na incorporação da estrutura cristalina dos elementos presentes nos resíduos, seja por meio de solução sólida ou intersticial, na formação de fases vítreas que atuam como matriz estável, imobilizando outras fases, dentre elas as referentes aos resíduos, ou a total fusão material, com formação de um vidro estável à lixiviação ou às condições agressivas do meio. ${ }^{(10)}$

Peric et al. (1996) pesquisaram a influência da incorporação de grânulos de polietilenos de alta e baixa densidade, PEAD e PEBD, respectivamente. Esses grânulos foram usados na preparação das matrizes de concreto no processo de imobilização de materiais de rejeito radioativo contendo césio. $O$ diâmetro das formas granuladas variava de $0,2 \mathrm{~mm}$ a $2,0 \mathrm{~mm}$.

Quatro tipos de PEAD e PEBD, formando quatro tipos de materiais de matriz, foram usados em vez dos grânulos de pedra de diâmetro médio de $2 \mathrm{~mm}$ 
comumente usados (para diminuir a porosidade e densidade da matriz de concreto e evitar a segregação de partículas de pedra no fundo da forma cilíndrica do rejeito radioativo imobilizado).

As características físico-químicas da forma melhoraram, especialmente o índice de lixiviação de radionuclídeos. Ele diminuiu de $4 \%$ para o material preparado com grânulos de pedra, para $2,5 \%$ a $3 \%$ para os materiais preparados com PEAD e PEBD.

As forças mecânicas das amostras de mistura de rejeito radioativo de concreto, preparadas com PEAD e PEBD, foram notavelmente mais altas (14MPa a $18 \mathrm{MPa}$, respectivamente) do que os monolitos preparados com os grânulos de pedra comum (11MPa). Ao usar PEAD e PEBD como grânulos na mistura de concreto de rejeito radioativo, o peso do monolito imobilizado inteiro final era de até $25 \%$ mais baixo do que o material com grânulos de pedra. ${ }^{(40)}$

Guzella e Silva (2001) avaliaram a técnica de condicionamento betuminoso. Essa técnica proporciona uma proteção física e radiologicamente estável para os estágios subseqüentes de gerenciamento de rejeitos, incluindo a disposição final.

$\mathrm{Na}$ época, o objetivo era imobilizar em betume o rejeito gerado no segundo reator nuclear de 1.300MW (PWR), em funcionamento no Brasil. Foi mencionado que alguns países utilizam regularmente o processo de banho betuminoso para imobilizar deferentes tipos de rejeitos. O processo tem sido investigado por muitos pesquisadores; na Suíça, o concentrado evaporado, a resina de troca iônica e os cartuchos de filtros têm sido processados com essa técnica desde 1980.

Numa outra abordagem, citaram o betume como o agente de solidificação preferido, porque tem demonstrado algumas vantagens, como baixo volume de sobras, boa permeabilidade e resistência à radiação e ao tempo.

Além disso, é possível incorporar rejeitos que tenham muitas propriedades químicas e físicas diferentes. Quando o betume é considerado como matriz para confinar rejeito radioativo, as suas propriedades físico-químicas são importantes, como são relacionadas, para as condições de transferência e estocagem do betume fundido, condições de operação do processo, compatibilidade com o rejeito, requisitos por embalagem e deposição final do produto do rejeito.

Nesse trabalho, foi aplicado o processo de extrusão para aquecimento e mistura do material. $\mathrm{O}$ rejeito foi misturado com betume com uma taxa de fluxo 
constante, para ser despejado em containeres apropriados. As amostras do produto foram analisadas por métodos padrões, entre eles, estudos das propriedades reológicas, calorimetria exploratória diferencial (DSC) e testes de lixiviação. ${ }^{(17)}$

Kalb et al. (2001) desenvolveram um método de microencapsulamento com polietileno (PE), que incorporava partículas de rejeitos misturadas dentro de uma matriz polimérica fundida, formando um rejeito final solidificado após seu resfriamento. Cada partícula individual de rejeito ficava incrustada dentro do bloco polimérico e era envolvida por uma cobertura durável e resistente à lixiviação.

Esse processo foi aplicado com sucesso para o tratamento de um amplo intervalo de rejeitos misturados: sais concentrados do evaporador, solos, lamas, cinzas do incinerador, soluções de escape de gás, soluções de descontaminação, resíduos do processo de oxidação de sais fundidos, resinas de troca iônica, carbono ativado em grãos, fragmentos de resíduos ativos secos, resíduos de limpeza, pós de urânio usados e restos de material de descontaminação.

Os autores também relataram que para fluxo de rejeitos contendo altas concentrações de contaminantes metálicos tóxicos solúveis, aditivos podiam ser usados para reduzir posteriormente a lixiviação, melhorando assim o carregamento de rejeitos de maneira que não excedesse os critérios de disposição regulamentados.

Nessa configuração, contaminantes eram estabilizados quimicamente e solidificados fisicamente, tornando o processo uma verdadeira tecnologia de estabilização/solidificação. Ao contrário de argamassa de cimento hidráulico convencional ou polímeros termofixos, polímeros termoplásticos, como o polietileno, não necessitavam de reações químicas para a solidificação. Portanto, um produto na forma de rejeito final, sólido e estável era assegurado no resfriamento.

Variações posteriores na química do rejeito não afetavam os parâmetros de processamento e não necessitavam de reformulação do processo. A incorporação de partículas do rejeito dentro da matriz polimérica servia como um agregado e melhorava a resistência mecânica e a integridade do rejeito. A força de compreensão de formas de rejeitos microencapsulados em polietileno variava com base no tipo e quantidade de rejeito encapsulado, mas era geralmente entre 
$7 \mathrm{MPa}$ e $17,2 \mathrm{MPa}$, bem acima da pressão mínima recomendada pela NRC (Nuclear Regulatory Commission) para rejeitos radioativos de baixo nível.

Como o PE é um material relativamente novo, é difícil prever sua durabilidade a longo prazo. Contudo, anteriormente ao dimensionamento do processo de microencapsulamento, foi feito um estudo para avaliar os mecanismos potenciais de degradação.

O estudo examinou o efeito potencial na integridade mecânica à exposição de produtos químicos e solventes, ciclos térmicos, ambientes saturados, ataques microbiológicos e altas doses de radiação gama. Em temperatura ambiente, o PE é relativamente inerte à maioria dos produtos químicos, incluindo solventes orgânicos ácidos e soluções alcalinas. Exposições a mudanças de temperatura ou condições de solos saturados mostraram degradar a integridade mecânica de algumas formas de rejeitos, mas tiveram pouco ou nenhum impacto mensurável nas formas de rejeitos encapsulados em polietileno.

O PEBD não é suscetível ao crescimento de micróbios, um fato que é evidenciado pela falta de decomposição dos plásticos em aterros de lixos municipais. Quando exposto à radiação gama em doses totais de até 108rad, ocorre reticulação adicional do polímero, resultando em um aumento de resistência e menor lixiviação. ${ }^{(41)}$

Evans et al. (2004) citaram que tecnologias desenvolvidas em vitrificação, cimentação e material polimérico manufaturado, utilizando material orgânico inflamável têm sido utilizadas para o encapsulamento de rejeitos sólidos, inclusive materiais de baixo nível de radioatividade, mas são impraticáveis para rejeitos contendo grande volume de sais.

Nesse trabalho, foi estudado um processo de emulsificação para produzir um molde de rejeitos numa matriz polimérica de base aquosa, como etapa preliminar para o desenvolvimento de matrizes de policerâmicas híbridas orgânicas/inorgânicas. $O$ material desenvolvido incorporou resina epóxi e látex poliestireno-butadieno (PSB) para produzir uma matriz não inflamável, leve, de custo relativamente baixo e com capacidade de ser carregada com grande volume de rejeito.

Foi usado nitrato de sódio como um modelo para rejeitos em forma de sais. Amostras em pequena escala foram feitas e analisadas por meio de testes com 
equipamentos projetados para medir o coeficiente de difusão e índice de lixiviação para as espécies de difusão mais rápidas e para rejeitos em forma de sais.

Os resultados mostraram que algumas porções de sais migraram em direção à superfície externa do molde de rejeito durante o processo de cura. $A$ porção do sal no interior da amostra ficou retida em corpúsculos poliméricos ou em cavidades. Estas últimas estavam incrustadas em uma fase de matriz polimérica que continha cristais finos de sais bem dispersos.

O comportamento de difusão observado no molde de rejeito indicou que amostras preparadas usando esse processo de emulsão satisfizeram ou superaram os limites de lixiviação sugeridos para encapsulamento de rejeito de baixo nível de radioatividade. ${ }^{(42)}$

Zakrzewska-Trznadel et al. (2004) relataram o emprego de membranas cerâmicas para processamento de rejeitos perigosos em experimentos numa usina piloto com soluções radioativas.

O método da membrana combinada foi aplicado para rejeitos perigosos contendo o processamento de substâncias radioativas. Tais agentes complexantes, como polímeros quelíferos solúveis e cianoferrosos de metais transientes testados e selecionados no laboratório, foram usados para ligar íons radioativos e aumentar o tamanho da molécula separada.

Os experimentos preliminares da usina piloto foram apresentados com instalação equipada com um módulo cerâmico. Os experimentos foram realizados com soluções modelo e rejeitos radioativos originais. Eles mostraram a prática de um método híbrido de complexação/ultrafiltração (UF) para reduzir a concentração de radioisótopos de meia-vida longa nos efluentes (saturados). As substâncias radioativas concentradas num pequeno volume podiam ser diretamente fossilizadas. ${ }^{(43)}$

Plecas et al. (2004) verificaram que resinas de troca iônica usadas contendo ${ }^{60} \mathrm{Co}$ e ${ }^{137} \mathrm{Cs}$ representam uma parcela principal dos rejeitos radioativos sólidos em tecnologia nuclear.

Cimento é usado como um material de solidificação para a estocagem de rejeitos radioativos de nível intermediário. Entretanto, a retenção de radionuclídeos, especialmente o césio, na matriz de cimento é insignificante. A absorção do césio no cimento é baixa e sua dispersão no cimento hidratado é alta. Somente quando o cimento é misturado com um material que tem uma 
capacidade de absorção expressiva, normalmente grãos ou pó de resina de troca iônica, é que a capacidade de lixiviação do césio e do cobalto da matriz de cimento é baixa o suficiente para ser aceitável. ${ }^{(44)}$

Maxwell et al. (1999) propuseram um método de dissolver resinas de troca iônica e recuperar actinídeos, terras raras ou metais pesados retidos, usando radiação de microondas. A resina saturada seria irradiada em um vaso fechado onde o uso de microondas permitiria um rápido aumento da temperatura da mistura a níveis aceitáveis para a digestão da resina, sem a necessidade do uso de ácidos desidratantes que poderiam danificar a estrutura da resina.

Essa irradiação seria mantida pelo tempo e com a energia necessária para que se processasse toda a digestão. Após a separação, os produtos perigosos poderiam ser imobilizados de forma segura, com redução de volume, ampliando o prazo de utilização da resina antes de se tornar exaurida. ${ }^{(45)}$ 


\section{OBJETIVOS}

O objetivo principal deste trabalho foi estabelecer uma metodologia limpa, econômica e de rápida aplicação, que utiliza a alta energia de microondas como fonte de aquecimento de materiais, para imobilização de rejeitos radioativos em matrizes compostas por betume reforçado por fibras poliméricas obtidas de borrachas vulcanizadas.

Em complemento ao método proposto foram experimentadas duas formas de transferir calor aos diferentes materiais nas diversas fases do trabalho, a incorporação de magnetita à matriz e uma forma de banho externo de magnetita.

Também foram testadas diferentes tipos de borrachas vulcanizadas, para melhorar as características mecânicas desta matriz de imobilização. 


\section{MATERIAIS E MÉTODOS}

\subsection{Amostras}

\subsubsection{Borrachas}

Três diferentes tipos de borracha vulcanizada foram experimentados na determinação da matriz base para imobilização:

- Neoprene ${ }^{\circledR}$ tipo "T", com densidade $1,23 \mathrm{~g} / \mathrm{cm}^{3}$ a $25^{\circ} \mathrm{C}$ e superfície lisa brilhante $^{(8)}$

- Etileno vinil acetato (EVA), com densidade $1,41 \mathrm{~g} / \mathrm{cm}^{3}$ a $25^{\circ} \mathrm{C}^{(46)}$

- Borracha de silicone, com densidade $1,11 \mathrm{~g} / \mathrm{cm}^{3}$ a $25^{\circ} \mathrm{C}^{(47)}$

\subsubsection{Betume}

Nas fábricas brasileiras de asfalto, localizadas em Cubatão (São Paulo) e em Fortaleza (Ceará), são extraídos produtos leves, como solventes, gasolina, nafta e também o betume. ${ }^{(16)}$

Todas as matrizes deste trabalho foram fundidas utilizando betume do tipo asfalto oxidado Viapo $^{\circledR}$ - VIT/90, cujas características físicas estão relacionadas na TAB. 1.

TABELA 1 - Especificações do betume tipo cimento asfáltico ${ }^{(48)}$

\begin{tabular}{ccc}
\hline Propriedades & Valores & Unidades \\
\hline Densidade & 1,02 a 1,04 & $\left(\mathrm{~g} / \mathrm{cm}^{3}\right.$ a $\left.25^{\circ} \mathrm{C}\right)$ \\
Ponto de Amolecimento & 85 a 95 & $\left({ }^{\circ} \mathrm{C}\right)$ \\
Ponto de Fulgor & $>250$ & $\left({ }^{\circ} \mathrm{C}\right)$ \\
\hline
\end{tabular}

Na FIG. 11, é apresentado um diagrama simplificado de uma coluna de destilação de petróleo a partir da extração do óleo cru. 


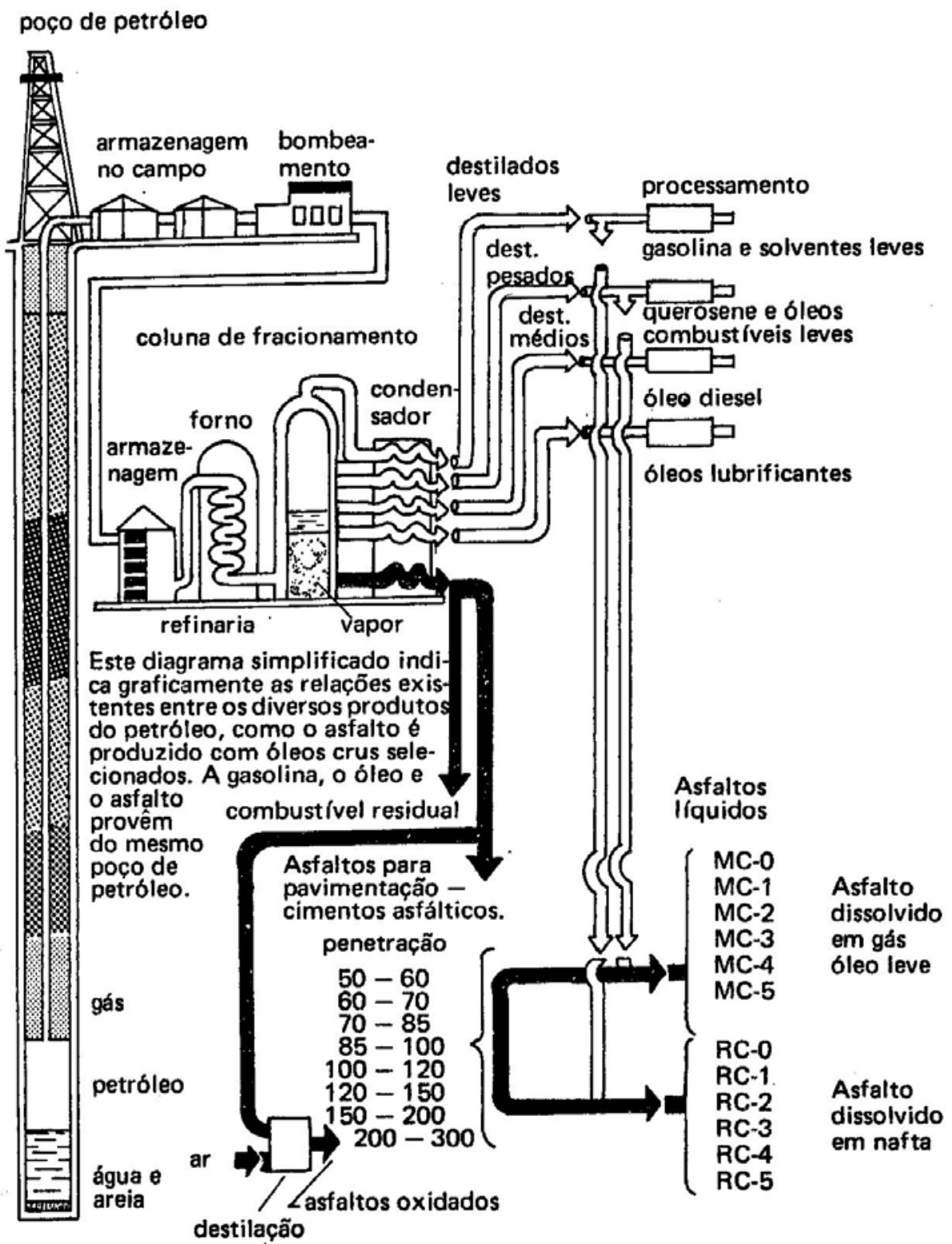

FIGURA 11: Diagrama simplificado de uma torre de fracionamento de petróleo ${ }^{(15)}$

\subsubsection{Resinas de troca iônica}

O tipo de resina de troca iônica utilizada foi a "Amberlite IRN 217" (TAB. 2), desenvolvida especificamente para tratamento químico da água do circuito primário do reator nuclear tipo "PWR" do IPEN. Esse tipo de resina apresenta propriedades, como alta capacidade de troca iônica, com grande resistência à fratura dos grânulos por atrito ou choque osmótico. 
TABELA 2 - Especificações da resina tipo Amberlite ${ }^{\circledR}-$ IRN $217^{(49)}$

\begin{tabular}{cc}
\hline Descrição & Característica \\
\hline Função & leito misturado \\
Porosidade & gel \\
Matriz & poliestireno - divinil benzeno (DVB) \\
Formulação & $7 \mathrm{Li}^{+} / \mathrm{OH}^{-}$ \\
Massa específica & $690 \mathrm{~g} / \mathrm{L}$ \\
Diâmetro das esferas & $>0,3 \mathrm{~mm}-0,2 \%$ \\
\hline
\end{tabular}

\subsubsection{Magnetita}

Como as moléculas da magnetita são polares, elas são sensíveis (absorvem) à radiação eletromagnética das microondas. Esse efeito é verificado com a taxa de aquecimento de aproximadamente $470^{\circ} \mathrm{C} / \mathrm{min}$ para o mineral natural ${ }^{(9)}$, possibilitando atingir temperaturas próximas de $1.000^{\circ} \mathrm{C}$.

Neste trabalho, foi utilizada magnetita natural com densidade de $5,2 \mathrm{~g} / \mathrm{cm}^{3}$ a $25^{\circ} \mathrm{C}$ de granulometria variada ${ }^{(9)}$, nos ensaios pelo método de banho e com a incorporação, no qual também foi testada magnetita produzida em laboratório de granulometria 200mesh na tentativa de fundir o betume juntamente com os demais componentes da matriz.

\subsubsection{Infra-estrutura}

Como infra-estrutura principal, foram utilizados equipamentos do Núcleo de Tecnologia de Polímeros do CQMA do IPEN:

- Forno microondas Panasonic, $127 \mathrm{~V}$, freqüência de microondas $2.450 \mathrm{MHz}$, potência de saída 1000W - MOD. NNS56BH;

- Balança Analítica Marte, precisão de 0,5g - MOD. LC2;

- Balança Analítica Quimis, precisão 0,0001g, capacidade 210g - MOD. Q500L210C;

- Termopar tipo "K";

- Chapa aquecedora Fisatom - 230V - 650W - MOD. 752 - A; 
- Estufa para secagem e esterilização, MOD. 400/ 4 - 200V;

- Microscópio de varredura - Phillips, modelo XL30.

\subsection{Irradiações}

Duas alternativas ilustradas na FIG. 12, foram testadas neste trabalho: banho de magnetita ou sua incorporação à matriz de imobilização.

As matrizes fundidas pelo método de banho de magnetita em forno de microondas, segundo as quantidades indicadas na TAB. 3 , foram utilizadas para verificação, tanto das características físicas das matrizes compostas por betume puro, quanto das características das matrizes alteradas pela adição separadamente de três diferentes tipos de borracha vulcanizada.

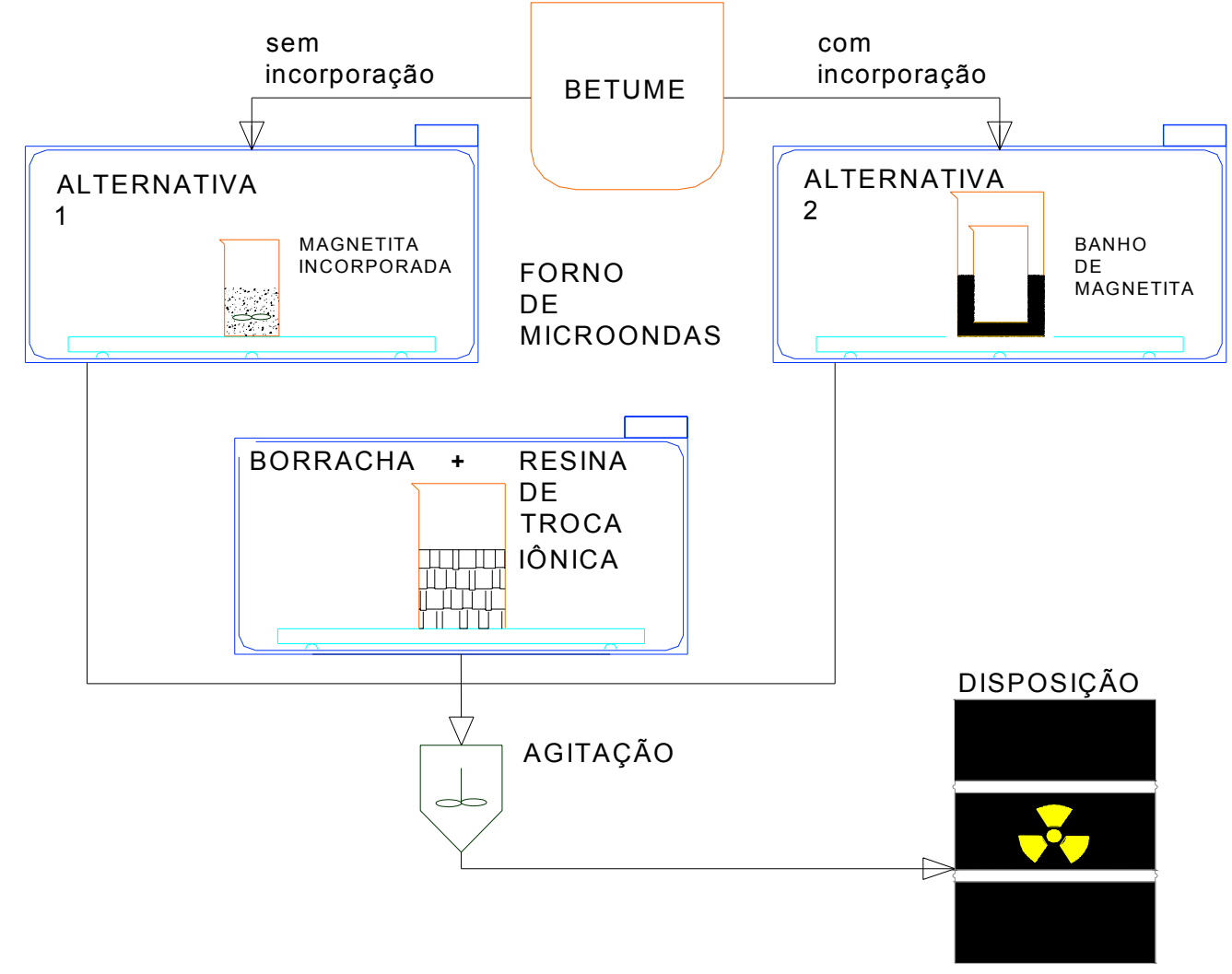

FIGURA 12: Diagrama de banho e incorporação de magnetita na matriz de imobilização

$\mathrm{Na}$ FIG.13, está representado o diagrama completo da montagem do método de banho. 


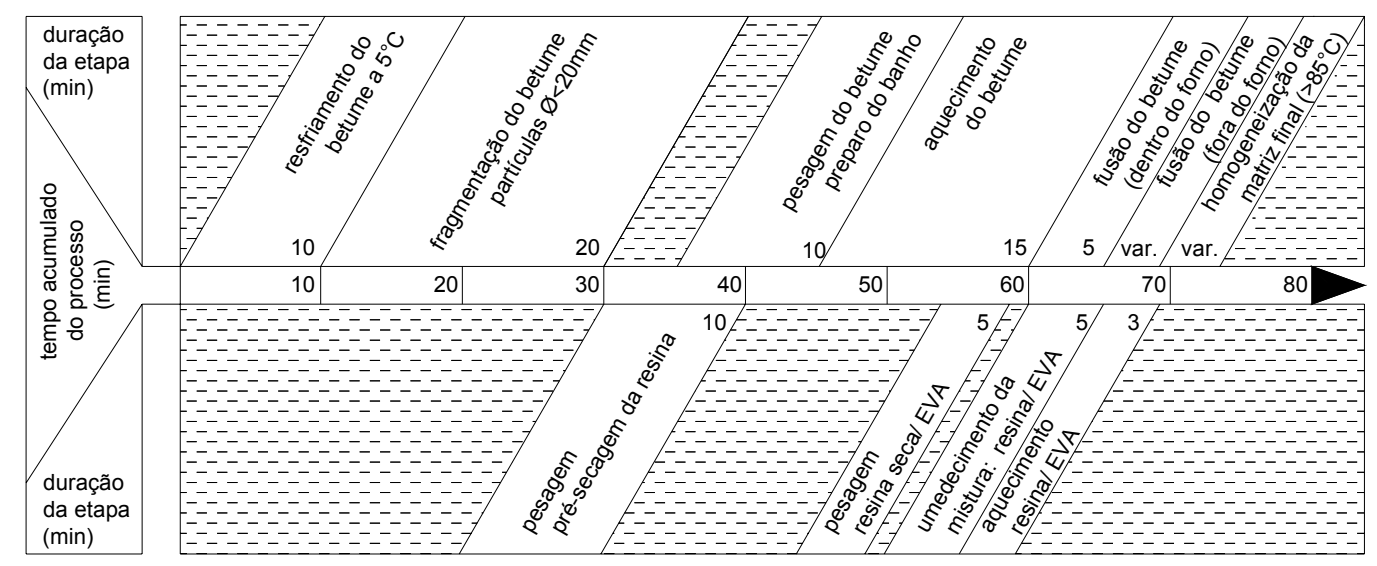

FIGURA 13: Diagrama do processo de imobilização pelo método de banho

Dessa grade de amostras (fase 1), os lotes que apresentaram os valores mais baixos para os ensaios de penetração definiram a borracha a ser incorporada juntamente com a resina de troca iônica na etapa seguinte do trabalho (fase 2).

TABELA 3: Composição das matrizes de betume e betume/polímero

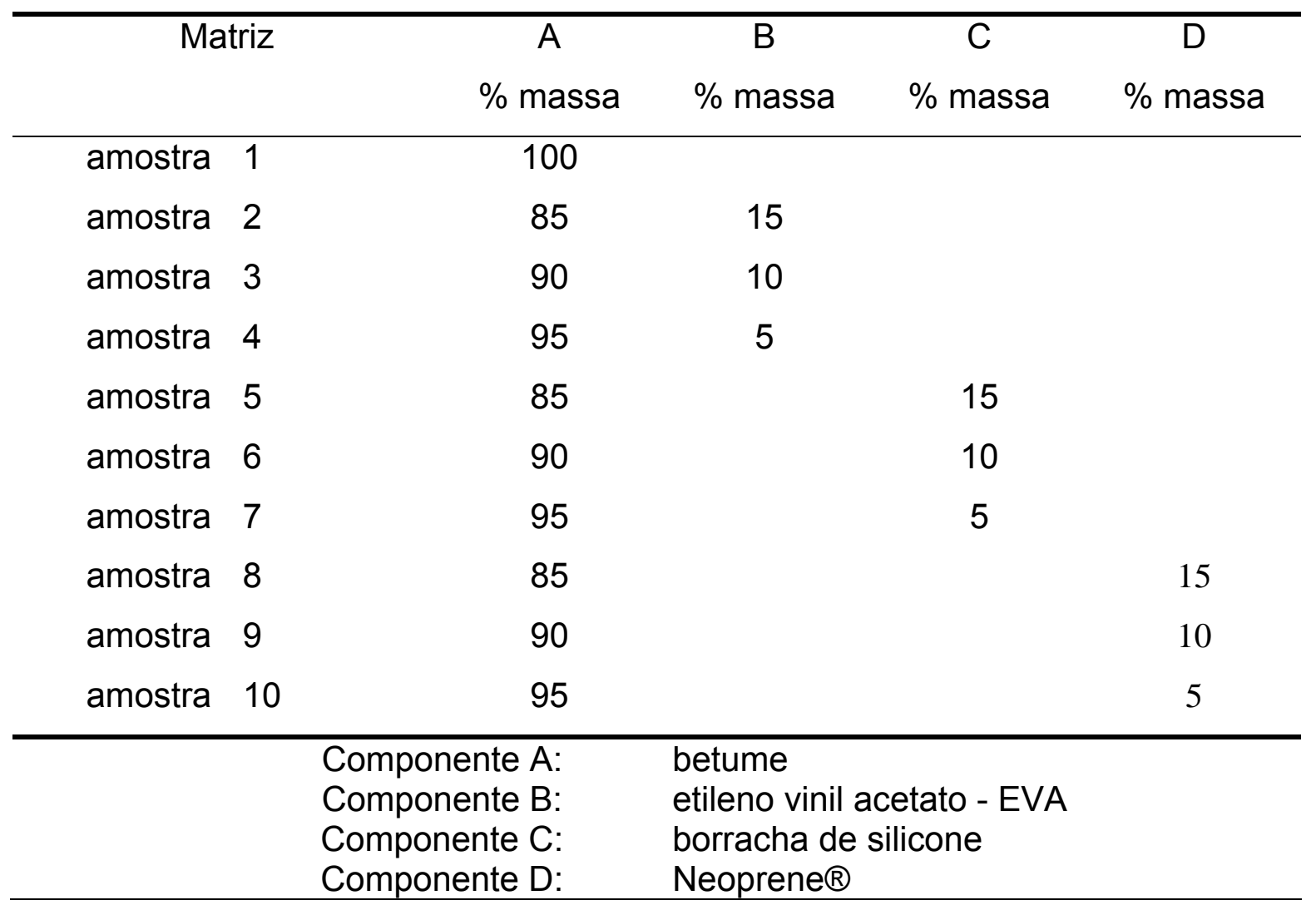


Ainda pelo método de banho de magnetita, as amostras foram analisadas e submetidas a novos testes mecânicos, ópticos e de lixiviação. Especificamente para a execução do teste de lixiviação, foram fundidas matrizes com a incorporação de resina impregnada de ${ }^{65} \mathrm{Zn}$.

A escolha das porcentagens de rejeito imobilizado, cujas matrizes foram submetidas aos testes da fase 2 , procurou seguir as quantidades experimentadas e disponíveis na literatura em testes de lixiviação, nos quais as porcentagens em peso variam de $40 \%$ a $55 \%$, dependendo do tipo de betume e do método de aplicação, ${ }^{(17,19)}$ resultando em matrizes sólidas e eficientes em todos os casos.

Para ser possível a fusão do betume, aquecimento da borracha e da resina, sem ocorrer sua degradação, o calor transferido por condução, da magnetita à matriz, foi mantido dentro dos limites definidos para cada material. Para o betume, $280^{\circ} \mathrm{C}$ (temperatura de fulgor), e $160^{\circ} \mathrm{C}$ para a resina (temperatura de formação de gás $\mathrm{SO}_{2}$ e liberação de aminoácidos explosivos provenientes da resina aniônica). ${ }^{(11)}$

Em uma segunda etapa, foi estudada a possibilidade de incorporação de magnetita aos componentes da matriz para se obter um aquecimento mais rápido do conjunto. Os parâmetros verificados foram: tempo de irradiação; potência de microondas; porcentagem em massa e forma de incorporação do mineral na matriz para cada uma das duas amostras de magnetita disponíveis.

Controlando a temperatura para não atingir valores abaixo do ponto de amolecimento do betume, foi possível a obtenção da matriz de imobilização (betume/ borracha/ rejeito) mediante agitação.

\subsubsection{Moldagem de corpos de prova de betume puro e os três polímeros pelo método de banho}

Para realizar a moldagem de corpos de prova conforme ilustrado na FIG. 14, os materiais foram pesados em balanças analíticas (Marte, modelo LC2, com precisão de 0,5g e Quimis, modelo Q500L210C, precisão 0,0001g e capacidade $210 \mathrm{~g}$ ) e posteriormente irradiados em um forno de microondas do tipo caseiro com prato giratório (Panasonic), freqüência de $2.450 \mathrm{MHz}$ e potência de saída de $1.000 \mathrm{~W}$, conforme metodologias descritas a seguir. As temperaturas das amostras foram medidas utilizando um termopar tipo "K". 
Em um béquer de vidro, adicionar $400 \mathrm{~g}$ de magnetita, sendo $130 \mathrm{~g}$ no fundo (como base) de outro béquer contendo $550 \mathrm{~g}$ de betume puro. $\mathrm{O}$ vão entre os dois béqueres deve ser preenchido (nivelando-se a superfície) com os $270 \mathrm{~g}$ restantes de óxido de ferro $\left(\mathrm{Fe}_{3} \mathrm{O}_{4}\right)$. Irradiar o conjunto no centro da cavidade do forno por 15 minutos e com $100 \%$ da potência de microondas, sendo mantido em descanso por 5 minutos, sem abrir a porta do forno. Após a retirada, o betume é agitado, se necessário, para fluidificação total de sua massa.

Transferir $400 \mathrm{~g}$ do betume para o molde (copo de papel parafinado de $500 \mathrm{~mL})$.

Durante o intervalo de 5 minutos de descanso da massa de betume, preparar o banho para aquecimento das borrachas. Neste passo, as quantidades e a distribuição de magnetita entre os dois béqueres são idênticas ao preparo com betume puro. Pesar a borracha, variando as porcentagens em massa $(5 \%$, $10 \%, 15 \%$ ) individualmente. Irradiar cada conjunto por 3 minutos com $100 \%$ da potência de microondas, após a retirada do conjunto com betume de dentro do forno.

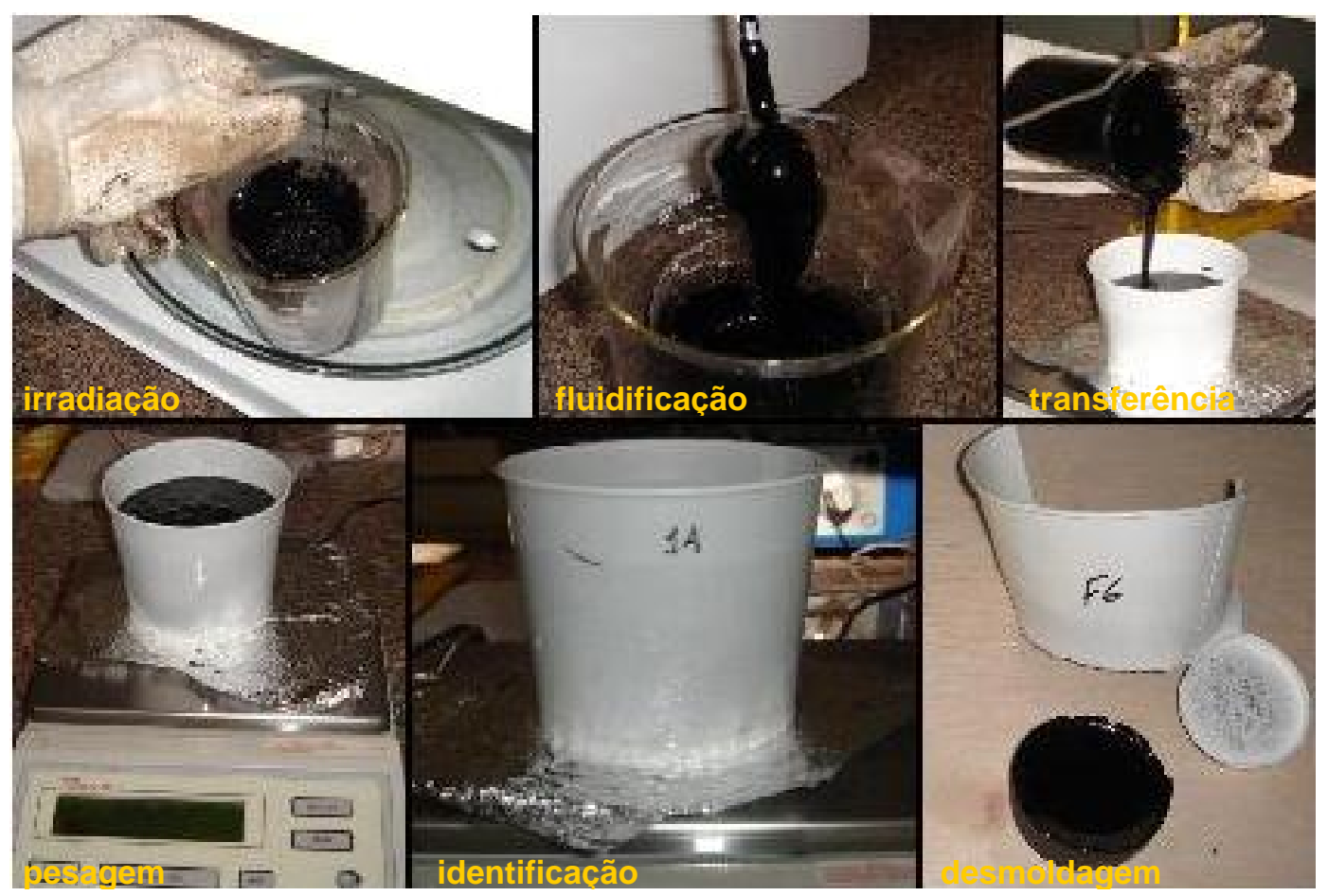

FIGURA 14: Moldagem de um corpo de prova de betume puro 


\subsubsection{Moldagem de corpos de prova com betume, borracha e resina pelo método de banho}

A partir dos resultados obtidos na fase 1 , foram calculados os valores das massas das amostras da fase 2, para a inclusão da resina de troca iônica. A massa total de $400 \mathrm{~g}$ por amostra foi mantida nesta fase.

Preparar um banho de magnetita para aquecer $550 \mathrm{~g}$ de betume puro, equivalente ao banho preparado na fase 1 (FIG. 15).

Pesar separadamente a resina seca e a borracha, segundo as quantidades indicadas na TAB. 4.

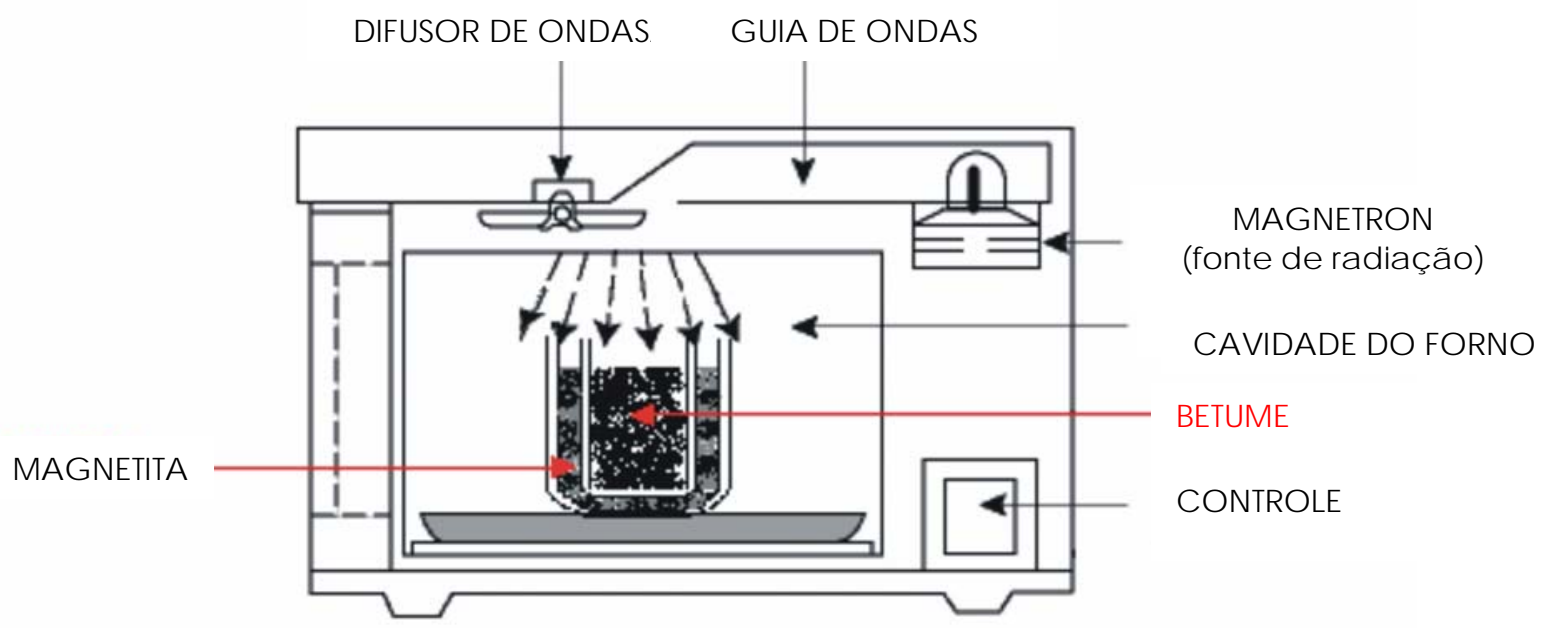

FIGURA 15: Esquema de montagem do aquecimento de betume em forno microondas

Juntar e homogeneizar esses dois componentes em um béquer de vidro, cujo aquecimento se dará em um banho similar ao do betume com $100 \%$ da potência de microondas e por 3 minutos, durante o período de descanso do betume fora do forno (FIG. 16).

Retirar do forno a mistura resina/borracha (EVA) aquecida e seca e transferir para o molde posicionado sobre o prato da balança. Transferir o betume sobre essa mistura, sob agitação vigorosa com bastão de vidro, até a obtenção de uma massa homogênea de $400 \mathrm{~g}$. Não continuar a operação em temperaturas abaixo de $85^{\circ} \mathrm{C}$. 
TABELA 4: Composição das matrizes de betume, resina e EVA

\begin{tabular}{cccc}
\hline $\begin{array}{c}\text { Identificação } \\
\text { dos lotes }\end{array}$ & $\begin{array}{c}\text { Massa de betume } \\
(\%)\end{array}$ & $\begin{array}{c}\text { Massa de resina } \\
(\%)\end{array}$ & $\begin{array}{c}\text { EVA } \\
(\%)\end{array}$ \\
\hline 11 & 50,0 & 50,0 & 0,0 \\
12 & 47,5 & 52,5 & 0,0 \\
13 & 45,0 & 55,0 & 0,0 \\
14 & 47,5 & 47,5 & 5,0 \\
15 & 47,5 & 42,5 & 10,0 \\
16 & 47,5 & 37,5 & 15,0 \\
17 & 45,0 & 40,0 & 15,0 \\
18 & 42,5 & 42,5 & 15,0 \\
19 & 40,0 & 45,0 & 15,0 \\
\hline
\end{tabular}

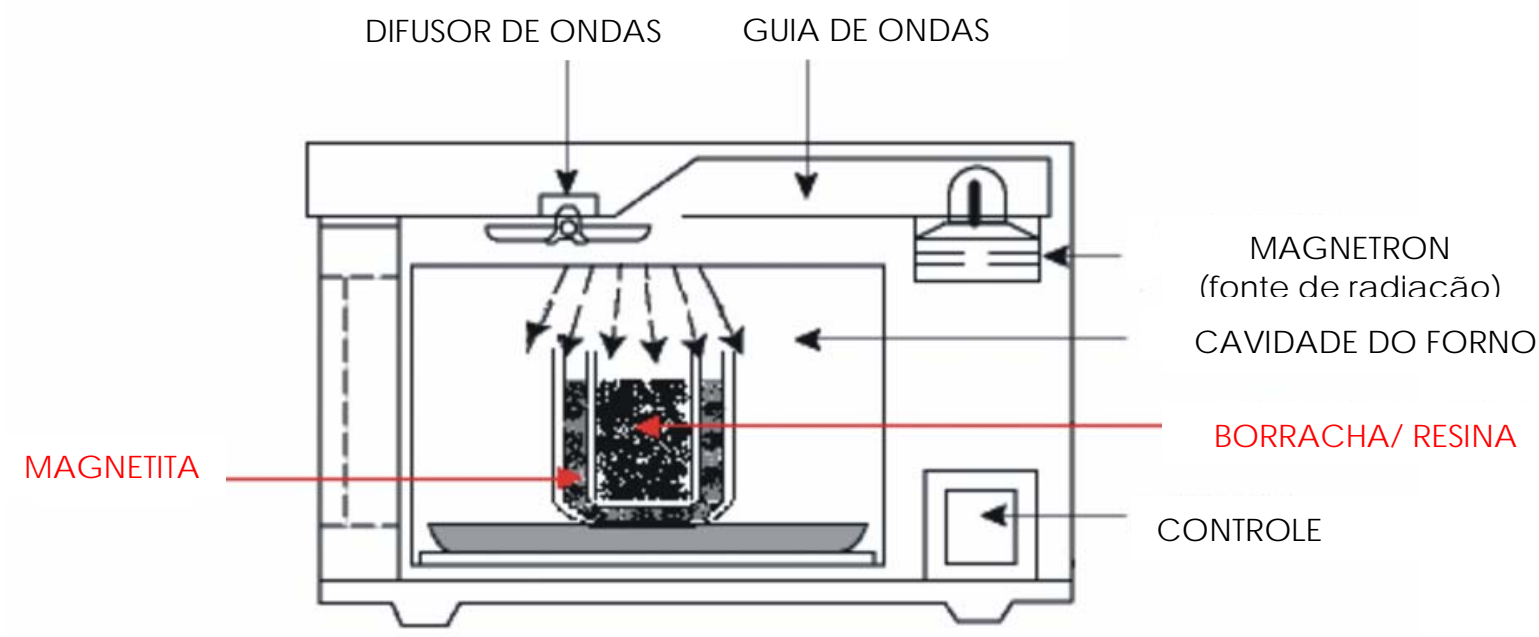

FIGURA 16: Esquema da montagem do aquecimento de EVA e resina em forno microondas

\subsection{Caracterizações}

As caracterizações desses materiais foram feitas por meio dos principais ensaios ou técnicas para comprovação de propriedades químicas, térmicas e mecânicas e seguiram as preconizações das normas da Associação Brasileira de Normas Técnicas (ABNT) e American Nuclear Society (ANSI/ANS). 
A análise termogravimétrica (TGA) foi executada no CQMA (Centro de Química e Meio Ambiente) do IPEN (Instituto de Pesquisas Energéticas e Nucleares).

Os ensaios de penetração, pontos de amolecimento, fulgor e combustão caracterizações foram executadas no Centro de Tecnologia de Obras de Infraestrutura do IPT (Instituto de Pesquisas Tecnológicas).

A microscopia eletrônica de varredura foi executada no CCTM (Centro de Ciência e Tecnologia de Materiais) do IPEN.

Os testes de lixiviação foram executados no CRN (Centro de Rejeitos Nucleares) do IPEN.

\subsubsection{Penetração (NBR 6576)}

A NBR $6576{ }^{(50)}$ define como penetração a distância em décimos de milímetros que uma agulha padrão penetra verticalmente na amostra de material, sob condições prefixadas, com carga de $100 \mathrm{~g}$ a um tempo de $5 \mathrm{~s}$ e a uma temperatura de $25^{\circ} \mathrm{C}$, mantida devido à imersão da amostra em um tanque com $10 \mathrm{~L}$ de água destilada. Na FIG. 17, estão ilustrados os passos do ensaio.

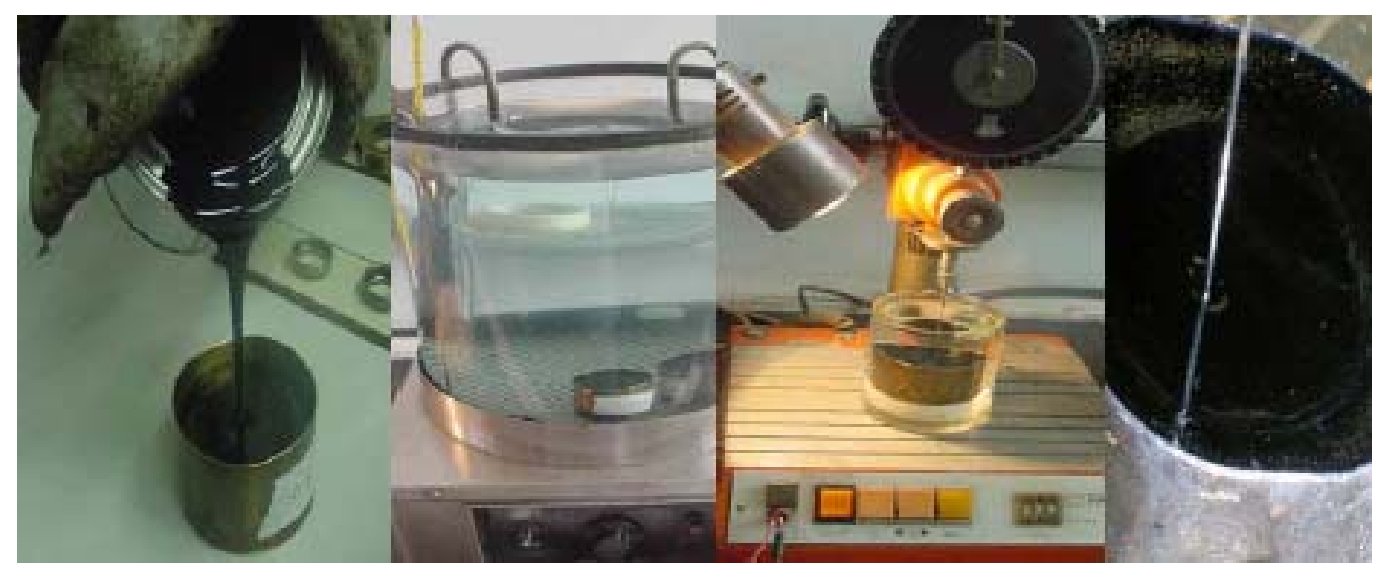

FIGURA 17: Moldagem, condicionamento, penetrômetro e detalhe da agulha ${ }^{(51)}$

O ensaio de penetração, em medidor SUR - MOD. PNR 6, banho Soiltest MOD. L226A, serviu para indicar a medida da resistência mecânica para deformação do material. Com a diminuição da profundidade de penetração, o betume passa de um comportamento flexível e dúctil para um comportamento mais rígido e frágil. 


\subsubsection{Ponto de amolecimento (NBR 6560)}

A determinação do ponto de amolecimento - anel e bola - foi realizada de acordo com a norma NBR $6560^{(52)}$ e define a medida da consistência que indica a tendência do material fluir sob a ação da temperatura, isto é, indica a temperatura mínima em que o bloco continua sólido. Por ser considerada uma medida de transição progressiva que cobre uma faixa grande de temperatura, resulta em uma noção da dureza ou da trabalhabilidade do betume. Este ensaio apresenta um comportamento inverso ao da penetração, pois quando o valor da penetração é elevado, o ponto de amolecimento é menor.

Neste ensaio, as amostras foram imersas em glicerina, veículo utilizado para ensaios entre $80^{\circ} \mathrm{C}$ e $157^{\circ} \mathrm{C}$. A montagem do teste é mostrada na FIG. 18.

A temperatura foi anotada no momento em que o material betuminoso atravessou o anel e tocou a placa metálica de referência.

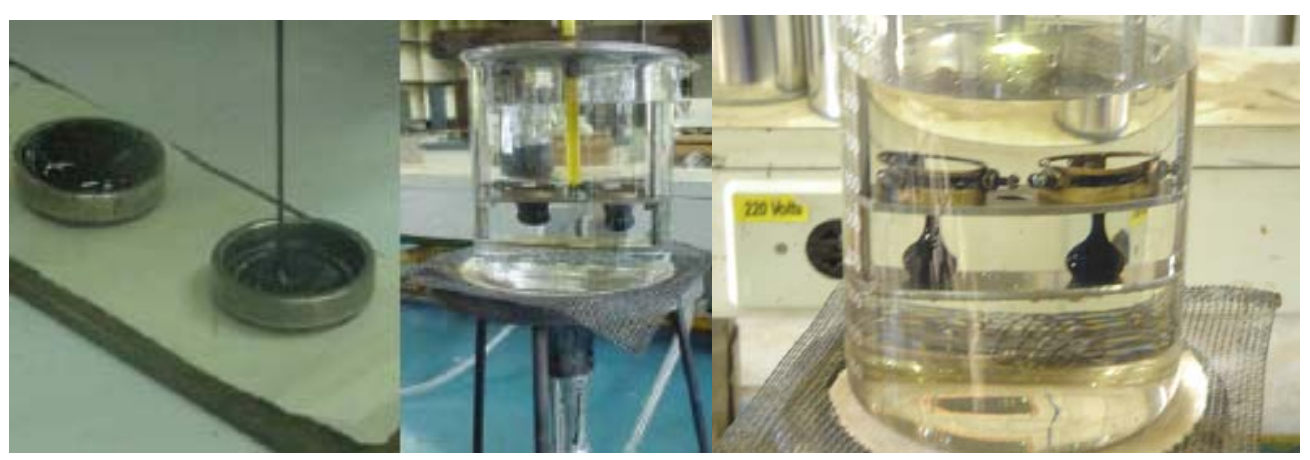

FIGURA 18: Moldagem dos $C P^{s}$ e detalhes do ensaio de amolecimento(51)

\subsubsection{Ponto de fulgor e combustão (NBR 11341)}

A determinação do ponto de fulgor em "vaso aberto de Cleveland", segundo a norma NBR $11341^{(53)}$, com chapa aquecedora de $220 \mathrm{~V}$ e $550 \mathrm{~W}$, indica a menor temperatura em que a chama causa ignição. A determinação do ponto de fulgor indica a medida da tendência da amostra de formar uma mistura inflamável com o ar sob condições laboratoriais (FIG. 19). Esse valor é usado na regulamentação de transporte e segurança. Valor baixo pode indicar a presença de material altamente volátil e inflamável na matriz. 
O ponto de combustão é a medida da tendência da amostra de se manter em combustão por um período não inferior a $5 \mathrm{~s}$.

O ensaio consiste em aumentar regularmente a temperatura do corpo de prova $(70 \mathrm{~mL})$ e passar uma chama a intervalos constantes sobre a matriz. Será anotada como ponto de fulgor a temperatura mais baixa que causar a ignição dos vapores, e ponto de combustão, a temperatura da queima por pelo menos 5 segundos.

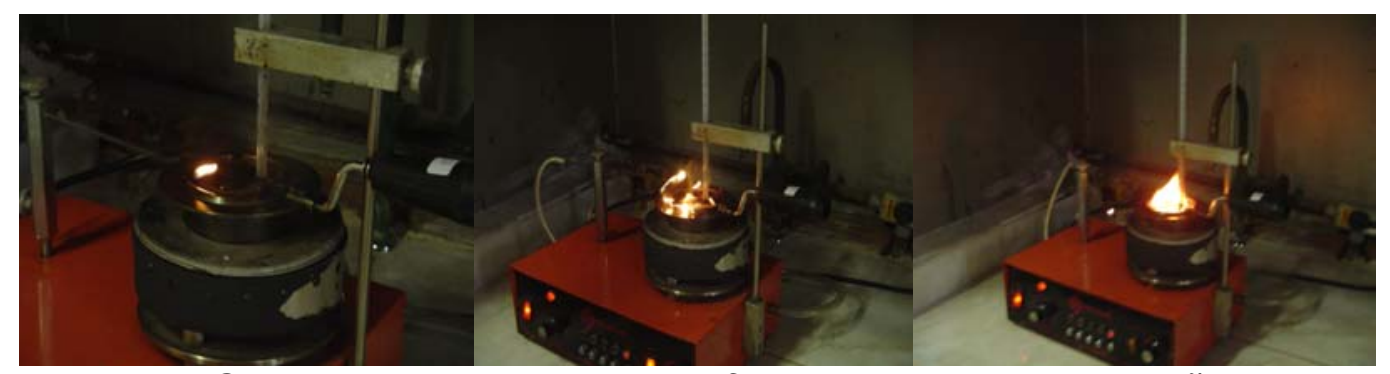

FIGURA 19: Ensaio ponto de fulgor, ponto de combustão

\subsubsection{Análise termogravimétrica (TGA)}

A análise termogravimétrica é definida como um processo contínuo que consiste no acompanhamento da perda de massa de uma determinada amostra em função da variação da temperatura.

Curvas de TGA foram obtidas em um equipamento fabricado pela Mettler Toledo, modelo TGA/STDA 851e, com taxa de aquecimento de $10^{\circ} \mathrm{C} \cdot \mathrm{min}^{-1} \mathrm{e}$ utilizando oxigênio como gás arraste.

\subsubsection{Microscopia óptica}

Técnica que permite avaliar a interação dos componentes da matriz de imobilização por meio da observação direta da imagem aumentada, e assim definir de que modo ela ocorre.

A junção das partículas pode se dar por meio de reação química ou física sob a ação das microondas. Se há reação química, a superfície da lâmina se mostra homogênea; no caso da união ser estritamente física, o limite dos materiais permanece definido. Neste caso, a ligação se dá pela adesividade (atrito) de pelo menos um dos componentes da matriz. 
O equipamento utilizado neste trabalho foi um microscópio de varredura, Phillips, modelo XL30.

\subsubsection{Resistência à lixiviação}

Esse ensaio mede a mobilidade do rejeito imobilizado na matriz betuminosa pela ação da água que, quando entra em contato com o rejeito, causa um lento transporte de partículas por difusão molecular, ou através dos poros por força de capilaridade. A sorção de água está associada com o inchamento e a formação de poros ou micro fraturas através das quais os radionuclídeos migram para fora da matriz. Dependendo da quantidade de resina e do seu volume de vazios, o inchamento pode provocar um aumento das pressões internas do bloco, ocasionando o rompimento das barreiras vizinhas. ${ }^{(54)}$

Para os testes de lixiviação neste trabalho, foi preparada uma matriz de imobilização a partir de $2,71 \mathrm{~g}$ de solução com $20 \mu \mathrm{g}{ }^{65} \mathrm{ZnCl}_{2} / \mathrm{g} \mathrm{HCl} 0,5 \mathrm{~mol} / \mathrm{l} \mathrm{com}$ $84,413 \mathrm{kBq}$ de atividade total, preparada pelo Instituto de Radioproteção e Dosimetria - IRD, contados em 11/04/2007, às 12:00, cuja meia vida média é de $244,01+-0,09 d$.

Foi feita a contagem em $50 \mathrm{~mL}$ de solução ${ }^{65} \mathrm{ZnCl}_{2} / \mathrm{g} \mathrm{HCl} 0,5 \mathrm{~mol} / \mathrm{l}$. Após a filtração em três volumes distintos de resina de troca iônica mista, os efluentes (50mL cada) gerados pelo processo de batelada foram igualmente contados (FIG.20). A taxa de lixiviação é medida pela variação de atividade de radionuclídeos na solução lixiviante, nos efluentes e nos corpos de prova, viabilizando ou não a amostra ANSI/ANS-16.1-2003. ${ }^{(17)}$

A radiação gama emitida pelas amostras foi medida em um detetor HPGe, modelo GX2518, marca Canberra, com fonte de ${ }^{60} \mathrm{Co}$.
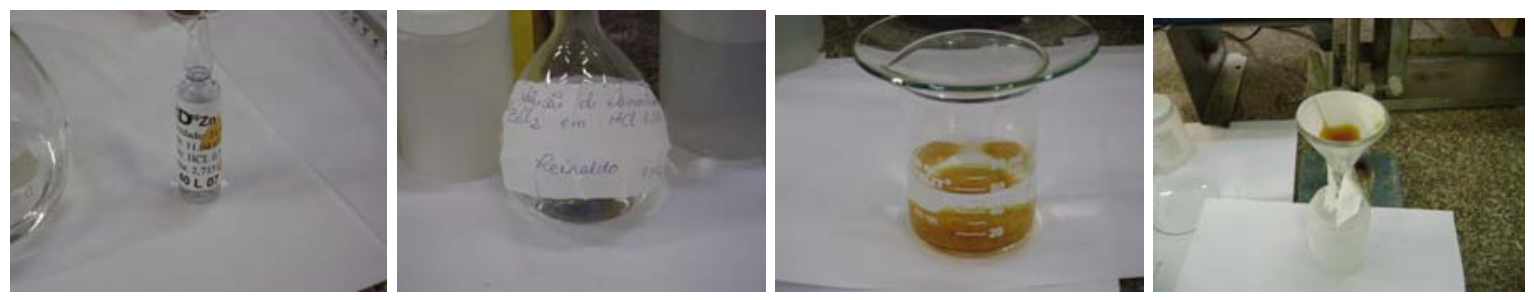

FIGURA 20: Solução padrão, alimentação, separação e efluentes 
Três matrizes de $14 \mathrm{~cm}^{3}$ foram moldadas pelo método de banho contendo $47.5 \%$ de resina impregnada com ${ }^{65} \mathrm{Zn}, 42,5 \%$ de betume e $10 \%$ de EVA em massa. Cada matriz foi acondicionada em baldes de PVC e submersa em 1,5mL de água destilada. A cada semana, foram encaminhados $50 \mathrm{~mL}$ de cada volume para contagem da atividade no material lixiviado. 


\section{RESULTADOS E DISCUSSÕES}

Os resultados estão assim ordenados:

- Teste TGA do betume puro;

- Método de aquecimento para os componentes da matriz;

- Parâmetros para misturar betume com borrachas, produção de amostras;

- Ensaios mecânicos, escolha da borracha mais adequada para a mistura;

- Definição de parâmetros para trabalhar com resina de troca iônica;

- Fusão de matrizes incorporando resina de troca iônica;

- Ensaios mecânicos, microscopia óptica e resistência à lixiviação.

Foi obtida a curva termogravimétrica (TGA) para uma amostra de $26,8341 \mathrm{mg}$ de betume VIT-90, no intervalo de $25^{\circ} \mathrm{C}$ a $1300^{\circ} \mathrm{C}$ em atmosfera oxidativa $\left(\mathrm{O}_{2}\right)$.

Do conjunto de eventos referentes à decomposição dos constituintes mais característicos do betume que estão ilustrados na FIG. 21, a ocorrência inicial foi a mais significativa no caso deste trabalho. A perda de massa inferior a $1 \%$ na faixa de temperatura até $250^{\circ} \mathrm{C}$, devido à evaporação de compostos gasosos e voláteis, demonstra que o betume selecionado (VIT-90) detém um comportamento resistente quanto à estabilidade térmica.

Sendo os asfaltos misturas complexas de hidrocarbonetos e seus derivados sulfonados e nitrogenados, cujas proporções dependem da origem da matéria prima ou da forma da obtenção dos produtos, ${ }^{(16)}$ as três próximas interpretações das ocorrências foram estimadas.

Dos três componentes básicos do asfalto, os óleos (massa molecular entre 250 e 600) que contém hidrocarbonetos aromáticos sólidos e ceras parafínicas foram decompostos a até $402,63^{\circ} \mathrm{C}$. No intervalo até $489,63^{\circ} \mathrm{C}$ as resinas foram decompostas (massa molecular 500 a 1000) seguidas da fração de constituintes mais pesados (massa molecular 1000 a 2500) denominados asfaltenos, decompostos entre $489,63^{\circ} \mathrm{C}$ e $605,96^{\circ} \mathrm{C}$.

O experimento foi encerrado a $895,93^{\circ} \mathrm{C}$ com $0,1270 \mathrm{mg}$ de massa de cinzas, que representam $0,4733 \%$ da massa inicial da amostra de betume. 
TGA Betume,25-1300,10-02

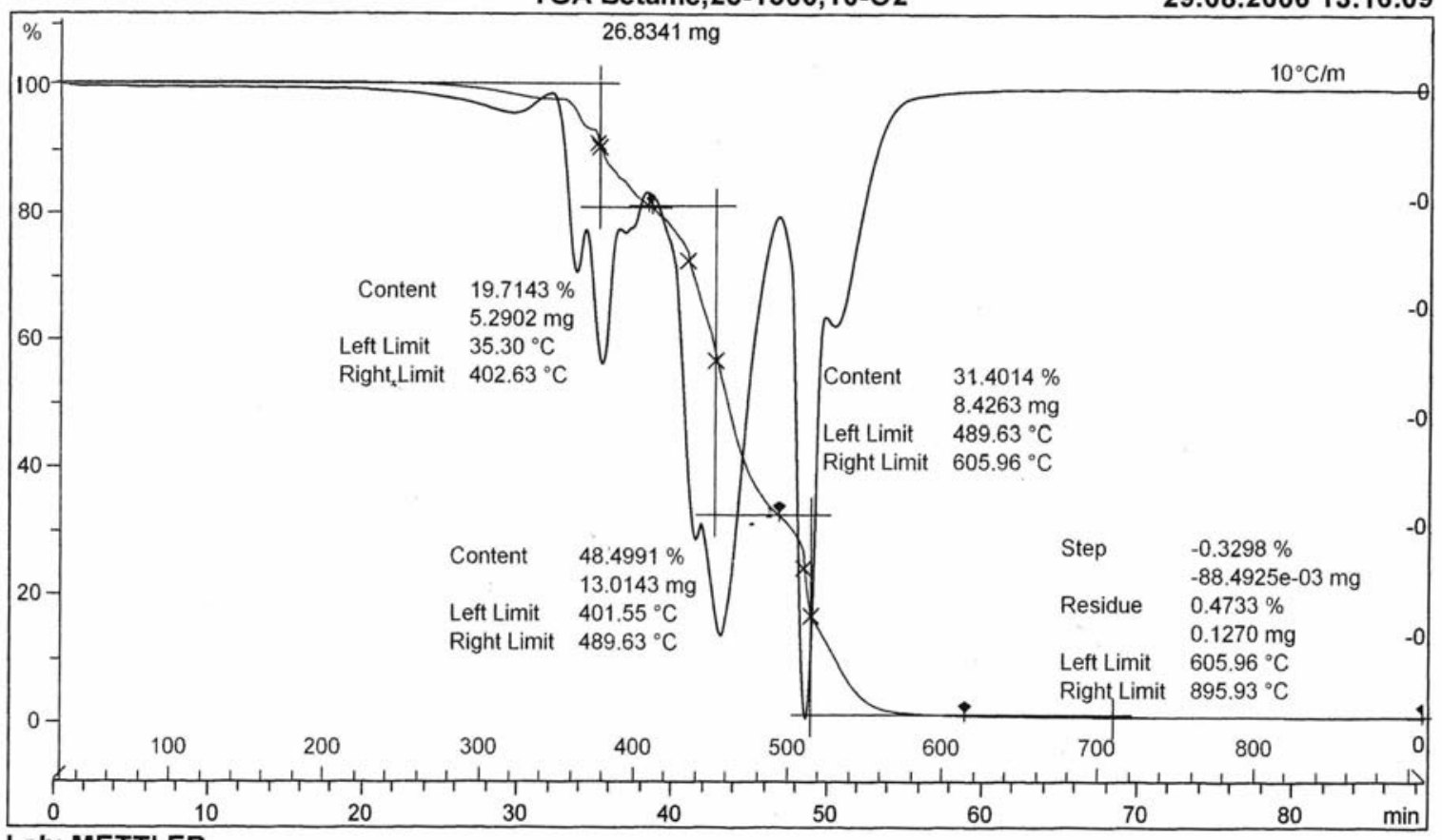

Lab: METTLER

FIGURA 21: Ensaio termogravimétrico em amostra de betume

$\mathrm{Na}$ tentativa inicial de definir os parâmetros (tempo de irradiação, potência de microondas e massa de betume) de fluidificação do betume puro com energia de microondas, foi possível observar que é mínima a porcentagem de moléculas absorvedoras de microondas entre os componentes do betume, as quais produzem um insignificante aquecimento da massa de betume.

Com a intenção de melhorar a ignição do betume, foram experimentados diferentes materiais líquidos e sólidos. Os produtos líquidos evaporaram ao atingir sua temperatura de ebulição, afetando apenas superficialmente a temperatura do betume; os produtos sólidos, como areia, pó de pedra sabão, granito e mármore também foram experimentados como agentes de ignição sem produzir efeito útil.

O aquecimento esperado somente foi atingido com a utilização de magnetita, e o comportamento de dois tipos diferentes foi observado.

Magnetita produzida em laboratório, com granulometria 200mesh, aquece a uma taxa de $150^{\circ} \mathrm{C} / 10 \mathrm{~s}$, e atingiu $450^{\circ} \mathrm{C}$ em $30 \mathrm{~s}$. Magnetita natural de densidade $5,3 \mathrm{~g} / \mathrm{cm}^{3}$ (Figura 22) atingiu $250^{\circ} \mathrm{C}$ no mesmo intervalo de tempo. 


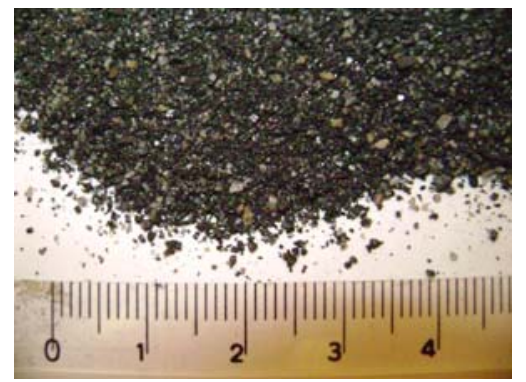

FIGURA 22: Magnetita natural sem classificação granulométrica

A pulverização de $1 \%, 3 \%$ ou $6 \%$ em massa de ambos os tipos de magnetita ao betume fragmentado, sob ação de microondas, causou a ignição dos voláteis presentes, ocasionando a carbonização do material antes mesmo do calor poder ser transmitido para todo o volume existente. A execução de um berço de magnetita com $0,5 \mathrm{~cm}$ de espessura sobre o fundo do béquer provocou a combustão dos voláteis do betume gerados nos vazios do seu volume. O mesmo ocorreu após a deposição de uma camada de $0,5 \mathrm{~cm}$ de magnetita sobre o betume para impedir a ventilação e a ignição. Neste caso, houve a fluidificação da camada superior do betume e sua infiltração para as camadas inferiores; porém, com uma rápida transferência de calor no sentido descendente, o conjunto esfriou, inviabilizando qualquer tentativa de mistura com outros materiais.

Com isso, ficou descartada a possibilidade de incorporação de magnetita à matriz de imobilização, pelas diferentes temperaturas de trabalho desses materiais, mesmo na presença de microondas.

Pelo método de banho de magnetita, foi possível controlar o avanço da temperatura com variações do tempo de irradiação e potência de microondas. Esse método impede o contato direto do mineral com o betume e seus complementos. Como a transferência do calor se dá por condução, é possível dirigi-la para todos os lados da matriz ao mesmo tempo.

$\mathrm{Na}$ melhor tentativa para a escolha do volume de magnetita do banho, $130 \mathrm{~g}$ foram depositados no fundo do béquer como base de apoio para o béquer que seria aquecido. O vão entre os dois béqueres foi preenchido com $270 \mathrm{~g}$ de magnetita, e a superfície superior do óxido ficou nivelada.

Inicialmente, foi montado o mesmo sistema de banho para aquecimento de $50 \mathrm{~g}$ de betume. A temperatura na magnetita foi medida em quatro pontos posicionados a $0^{\circ}, 90^{\circ}, 180^{\circ}$ e $270^{\circ}$ em relação ao eixo das abscissas e 
rotacionados no sentido anti-horário (FIG. 23). Com a temperatura ambiente a $23^{\circ} \mathrm{C}$, o betume atingiu $157^{\circ} \mathrm{C}$, e a magnetita atingiu $280^{\circ} \mathrm{C}$ ao final de $100 \mathrm{~s}$ de irradiação a $100 \%$ da potência de microondas.

A seguir, foi verificado o comportamento de uma massa de $400 \mathrm{~g}$ de betume em banho equivalente, sob irradiação também a 100\% de potência em um forno de microondas do tipo caseiro Panasonic, $127 \mathrm{~V}$, de freqüência de microondas 2450MHz e potência de saída 1000W - MOD. NNS56BH.

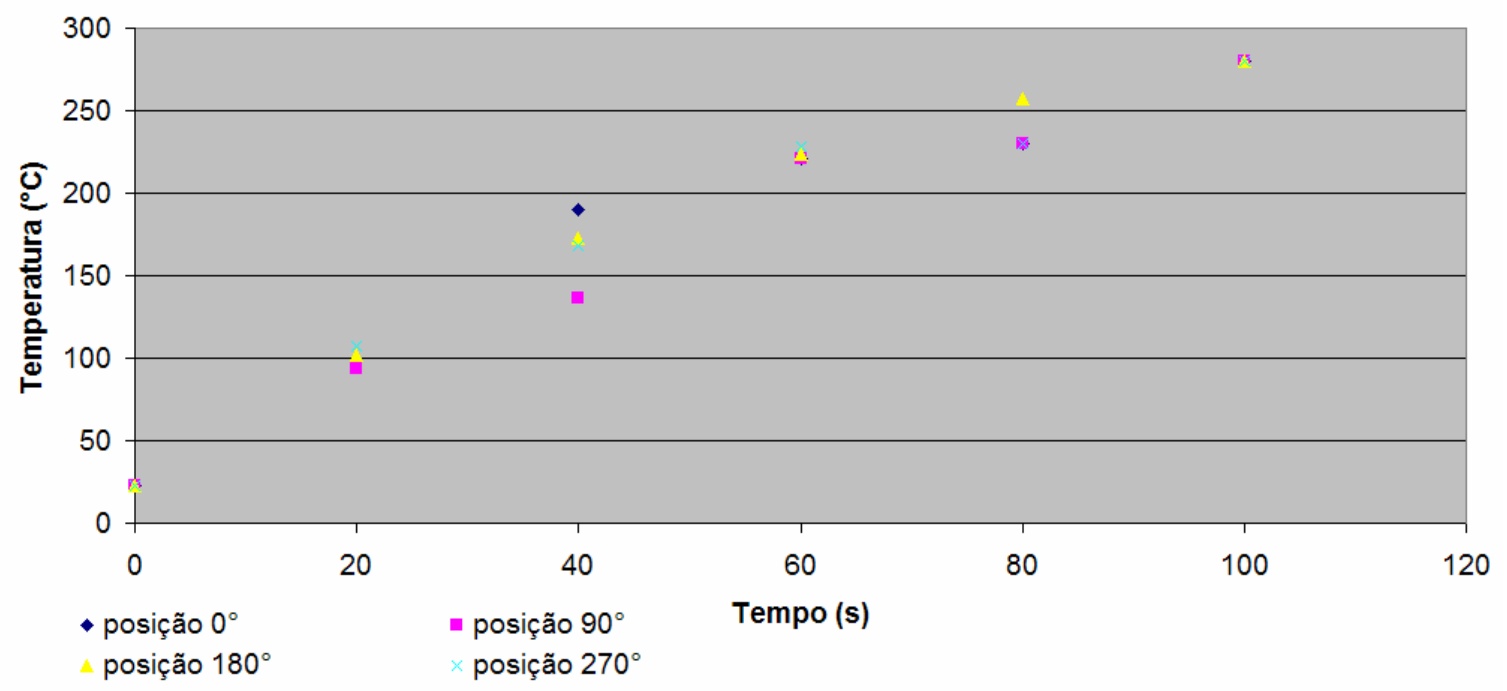

FIGURA 23: Comportamento do banho de magnetita para $50 \mathrm{~g}$ de betume

O conjunto foi retirado do forno a cada 3 minutos de irradiação para monitoração da temperatura da massa de betume por meio de um termopar tipo "k". Ao final de 42 minutos de irradiação, a temperatura da massa atingiu $235^{\circ} \mathrm{C}$ (FIG. 24). A necessidade de retirar o conjunto de dentro do forno para a verificação da evolução da temperatura definiu vários patamares na curva de aquecimento.

Nova exploração foi executada (FIG. 25) com irradiação ininterrupta até 20 minutos a $100 \%$ da potência de microondas; a seguir, a evolução da temperatura foi monitorada a cada 3 minutos até completar 32 minutos. Foi possível verificar a diminuição do tempo necessário de irradiação, bem como a existência de patamares na evolução da temperatura do betume. 


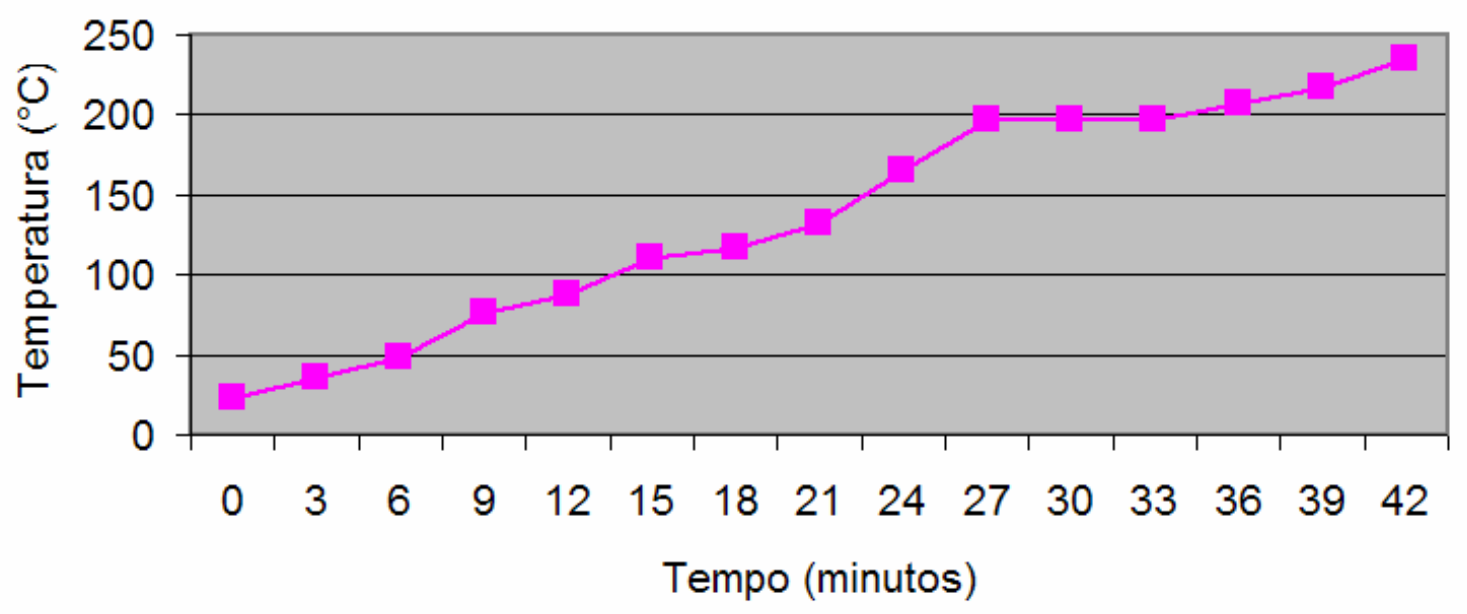

Figura 24: Aquecimento de betume em banho de magnetita (exploração 1)

Maior aproveitamento do calor conduzido pela magnetita na fusão do betume foi conseguido com 0 uso de fragmentos de betume de dimensões inferiores a $10 \mathrm{~mm}$. A fragmentação manual por meio de vigorosos golpes com massa metálica é conseguida mais facilmente após o resfriamento do betume em banho de gelo ou freezer até a temperatura passar abaixo de $10^{\circ} \mathrm{C}$ ou por meio da imersão em nitrogênio líquido. Essas dimensões dos fragmentos foram utilizadas na obtenção da totalidade das amostras ensaiadas neste trabalho. Dessa forma, foi definido o tempo de 15 minutos de irradiação a $100 \%$ da potência de microondas para que, em $130 \mathrm{~g}$ como base e $270 \mathrm{~g}$ como revestimento lateral de magnetita, $400 \mathrm{~g}$ de betume inicialmente fragmentado em pedaços de diâmetro inferior a $10 \mathrm{~mm}$ fundissem à temperatura de $230^{\circ} \mathrm{C}$.

Comparando com o aquecimento por microondas, em uma chapa aquecedora Fisatom, Mod. $752^{\mathrm{A}}$ série 401797 de $230 \mathrm{~V}$ e $650 \mathrm{~W}$, regulada para $350^{\circ} \mathrm{C}$, são necessários 100 minutos para a mesma massa de betume atingir $230^{\circ} \mathrm{C}$. (FIG. 26). Neste caso, a monitoração da temperatura se deu de forma continuada, sem retirar a amostra de cima da chapa. 


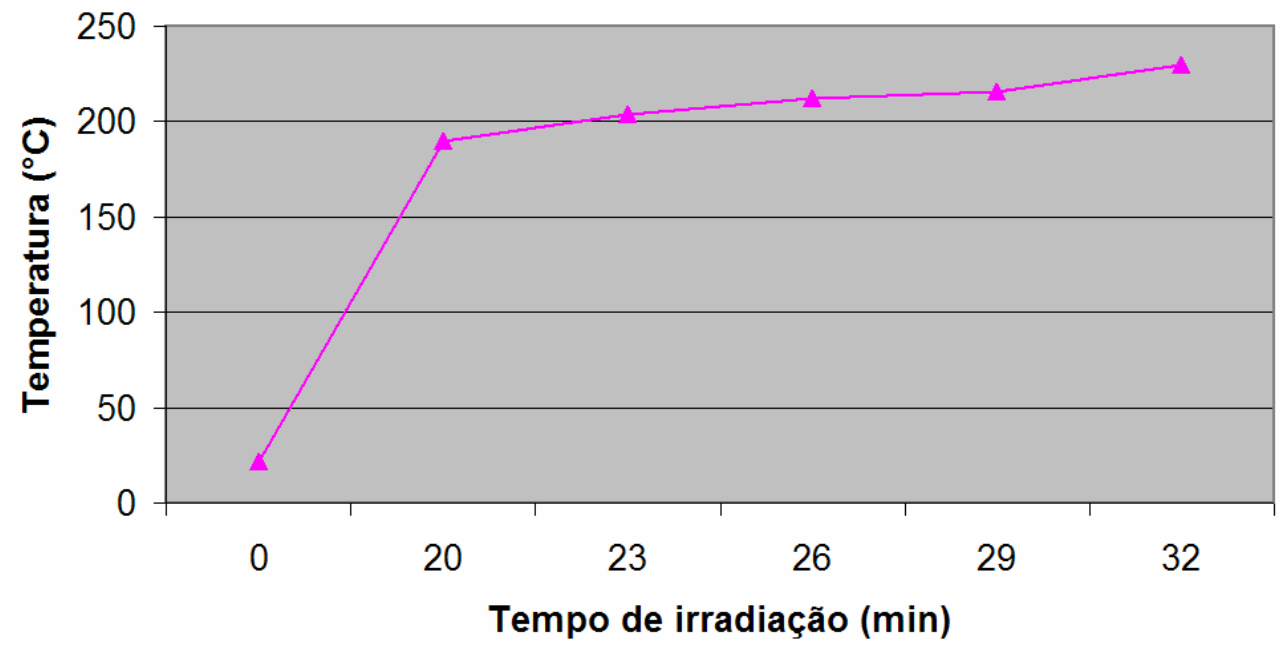

Figura 25: Aquecimento de betume em banho de magnetita (exploração 2)

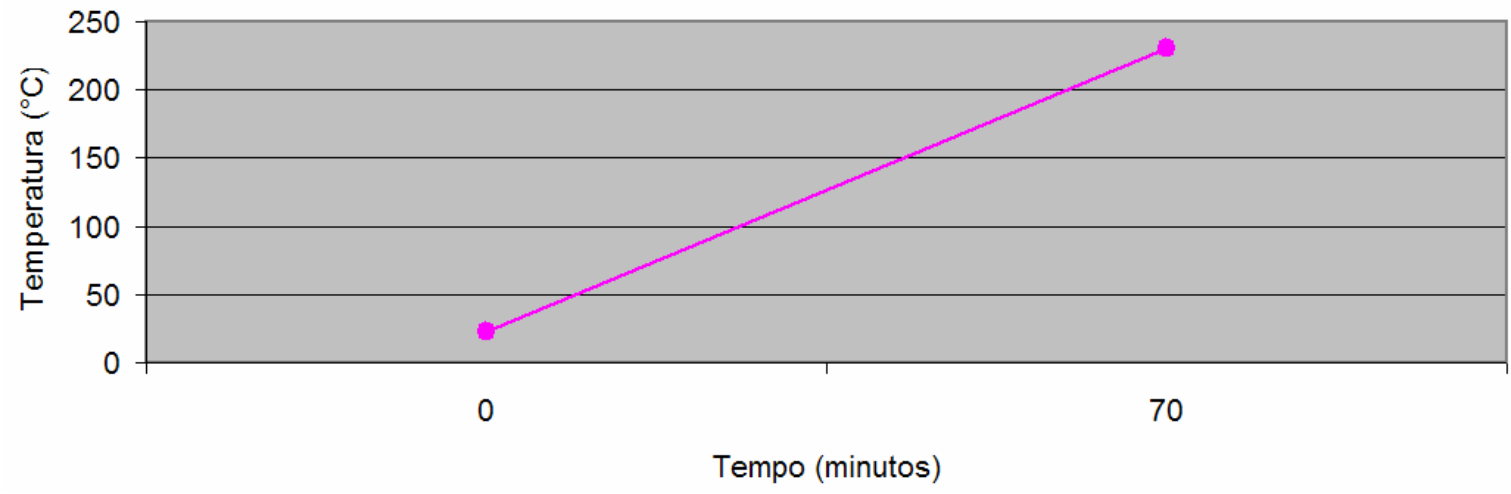

FIGURA 26: Aquecimento de betume em chapa aquecedora

Estão apresentados na TAB. 5 os valores padrão para asfaltos oxidados e os valores indicados pelo fabricante do betume aqui utilizado para comparação com os valores médios obtidos, medidos nas matrizes estudadas a seguir.

TABELA 5: Comparação entre propriedades de asfaltos oxidados padrão e utilizado ${ }^{(15,48)}$

\begin{tabular}{cccc}
\hline Propriedades & Unidades & Valores padrão & VIT - 90 \\
\hline Densidade & $\mathrm{g} / \mathrm{cm}^{3}$ a $25^{\circ} \mathrm{C}$ & 1,02 a 1,04 & - \\
Ponto de & ${ }^{\circ} \mathrm{C}$ & 70 a 140 & 85 a 95 \\
Amolecimento & ${ }^{\circ} \mathrm{C}$ & 250 a 290 & $>250^{\circ} \mathrm{C}$ \\
Ponto de Fulgor & $\mathrm{mm} / 10$ a $25^{\circ} \mathrm{C}$ & 7 a 45 & 5 a 15 \\
Penetração & &
\end{tabular}


Em seguida, foi monitorado o comportamento da matriz betuminosa quando em resfriamento para a homogeneização dos materiais a serem imobilizados. Com temperatura ambiente de $22^{\circ} \mathrm{C}$ e temperatura inicial de $235^{\circ} \mathrm{C}$, foi elaborada a curva temperatura $X$ tempo até o valor mínimo de $85^{\circ} \mathrm{C}$, ponto de amolecimento do betume utilizado (FIG. 27).

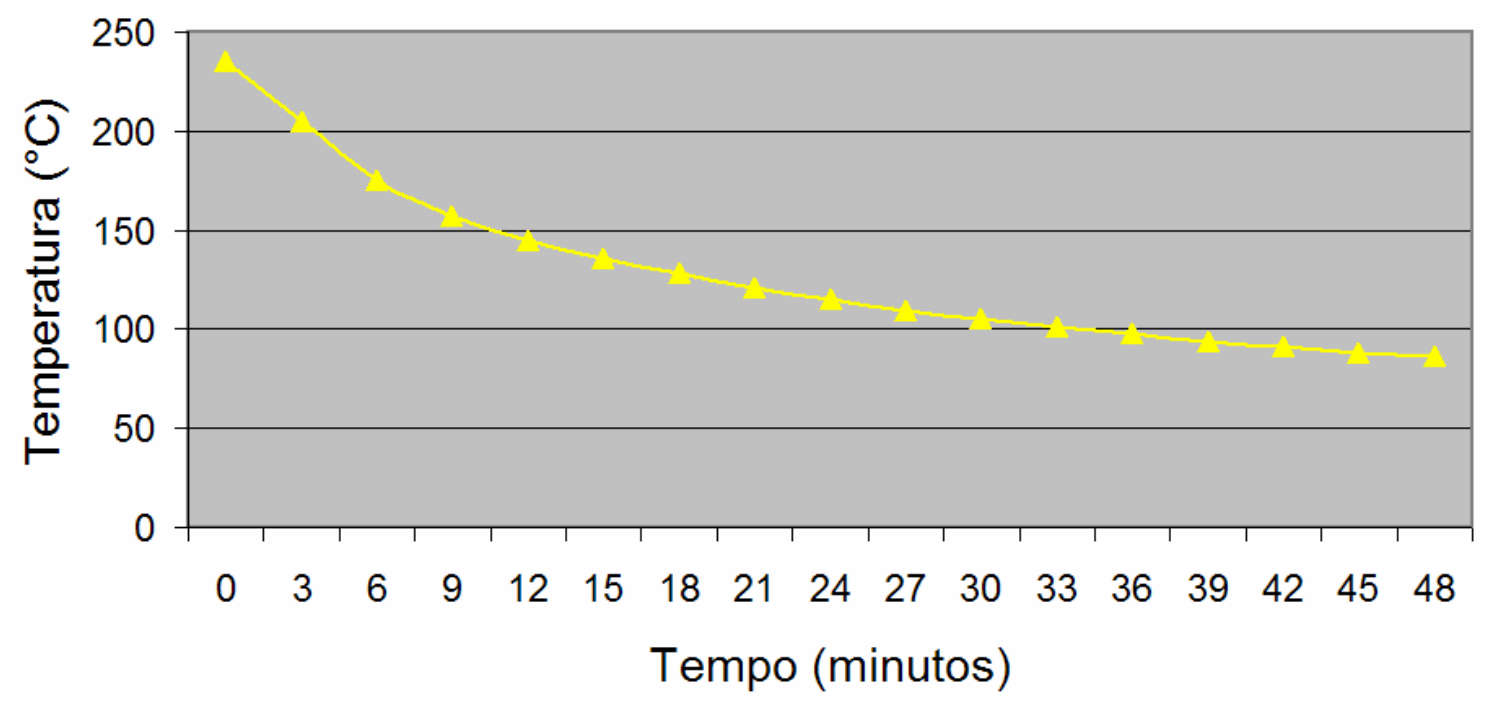

FIGURA 27: Curva de resfriamento do betume puro

A partir dessas considerações, foram elaboradas amostras de matrizes compostas de betume puro para serem comparadas com os valores disponíveis na literatura, para os ensaios dos pontos de amolecimento, fulgor, combustão e penetração. Os mesmos ensaios foram aplicados em uma série de amostras, variando individualmente as quantidades de três diferentes tipos de polímeros: EVA, borracha de silicone e Neoprene $\AA$, com o objetivo de se obter um incremento na resistência mecânica das matrizes de imobilização.

Dez lotes de amostras foram fundidos segundo os procedimentos indicados nos itens 4.2 e 4.2.1, e as amostras levadas ao laboratório do Centro de Tecnologia de Obras e Infra-estrutura (CT-Obras) do IPT onde foram realizados testes para caracterização dessas matrizes, com a determinação das temperaturas de amolecimento, fulgor e combustão e dos valores de penetração.

Os resultados médios dos ensaios de penetração $(1 / 10 \mathrm{~mm})$ estão indicados na TAB. 6. 
TABELA 6: Resultados do ensaio de penetração

\begin{tabular}{ccccccccccc}
\hline Leitura & \multicolumn{11}{c}{ Lote } \\
\hline & 1 & 2 & 3 & 4 & 5 & 6 & 7 & 8 & 9 & 10 \\
Penetração (1/10mm) & 7,0 & 2,0 & 3,3 & 6,0 & 7,5 & 7,5 & 7,3 & 8,0 & 7,7 & 7,3 \\
\hline
\end{tabular}

Os resultados médios dos ensaios de temperatura de amolecimento, fulgor e combustão, em que se pode verificar que todos os valores obtidos para os pontos de fulgor são superiores aos valores atribuídos ao betume oxidado puro $\left(250^{\circ} \mathrm{C}\right)$, estão mostrados na $\mathrm{TAB} .7$.

Dos resultados mostrados nas Tabelas 6 e 7 , os lotes de nos 2 e 3 , identificados pela cor azul, apresentaram maiores alterações em relação aos demais lotes analisados. Os valores de penetração e amolecimento medidos indicam um ganho de $15 \%$ em relação aos índices de resistência para o padrão do betume puro indicado na TAB. 5, pg. 50. Desses valores, foram calculadas as porcentagens (TAB. 4, pg. 39) de materiais que compuseram as matrizes de betume/EVA para imobilização de resina do tipo IRN-217, separada de um lote de material que é utilizado no sistema primário de purificação da água de refrigeração do reator IEA-R1 situado no IPEN.

O surgimento de múltiplas bolhas, tanto na superfície como no interior da matriz de imobilização, levou à necessidade de se trabalhar com rejeito seco. Os vazios observados, além de transformarem o monolito em um bloco poroso, portanto com baixa resistência mecânica, também facilitam a infiltração de água e conseqüente careação de radionuclídeos para fora da matriz, podendo vir a contaminar o meio ambiente.

Dois métodos foram comparados para secagem da resina, utilizando uma estufa elétrica e um forno de microondas.

Cinco amostras com aproximadamente $10 \mathrm{~g}$ de resina foram mantidas em uma estufa de secagem (estufa para secagem e esterilização, MOD. 400/ 4 $200 \mathrm{~V}$ ) a $110^{\circ} \mathrm{C}$ constantes. Com a massa monitorada a cada 60 minutos, a evaporação da fase líquida foi dada por completa ao se verificar a estabilidade da perda de massa pela resina (FIG. 28). 
TABELA 7: Médias dos resultados de caracterização das matrizes

\begin{tabular}{cccc}
\hline Lote & \multicolumn{3}{c}{ Média das Temperaturas } \\
\cline { 2 - 4 } & Amolecimento $\left({ }^{\circ} \mathrm{C}\right)$ & Fulgor $\left({ }^{\circ} \mathrm{C}\right)$ & Combustão $\left({ }^{\circ} \mathrm{C}\right)$ \\
\hline 1 & 90,65 & 315,6 & 342,6 \\
2 & 120,5 & 275,0 & 297,0 \\
3 & 104,6 & 329,0 & 357,0 \\
4 & 94,1 & 329,0 & 354,0 \\
5 & 96,3 & 325,0 & 342,0 \\
6 & 92,9 & 327,0 & 349,0 \\
7 & 90,3 & 337,0 & 360,0 \\
8 & 96,0 & 300,0 & 320,0 \\
9 & 92,5 & 308,0 & 326,0 \\
10 & 91,5 & 328,0 & 344,0 \\
\hline
\end{tabular}

O ensaio foi repetido com outras 5 amostras de massa aproximada de $30 \mathrm{~g}$. A estabilização ocorreu após 20 horas na mesma estufa, com temperatura constante a $100^{\circ} \mathrm{C}$ (FIG. 29).

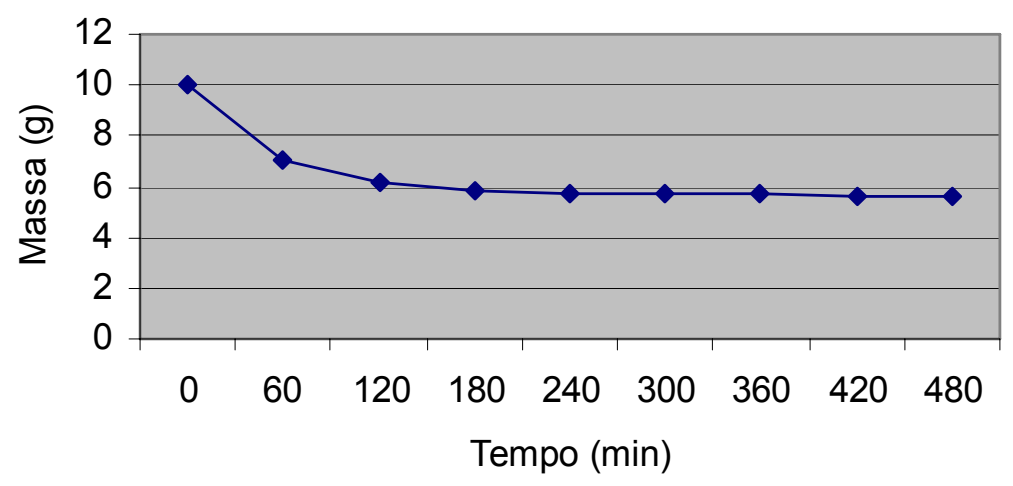

FIGURA 28: Secagem de $10 \mathrm{~g}$ de resina em estufa a $110^{\circ} \mathrm{C}$

A secagem prévia da resina foi otimizada segundo os dados mostrados na FIG. 30, quando foi utilizado um forno de microondas. Em 390s (6,5min), 10,42g de resina apresentaram a mesma perda de líquidos medida no teste com estufa, estabilizando a massa final em $6,30 \mathrm{~g}$. Pequenas variações na massa da resina 
seca após 300s de irradiação foram devidas à sua hidratação pela umidade ambiente.

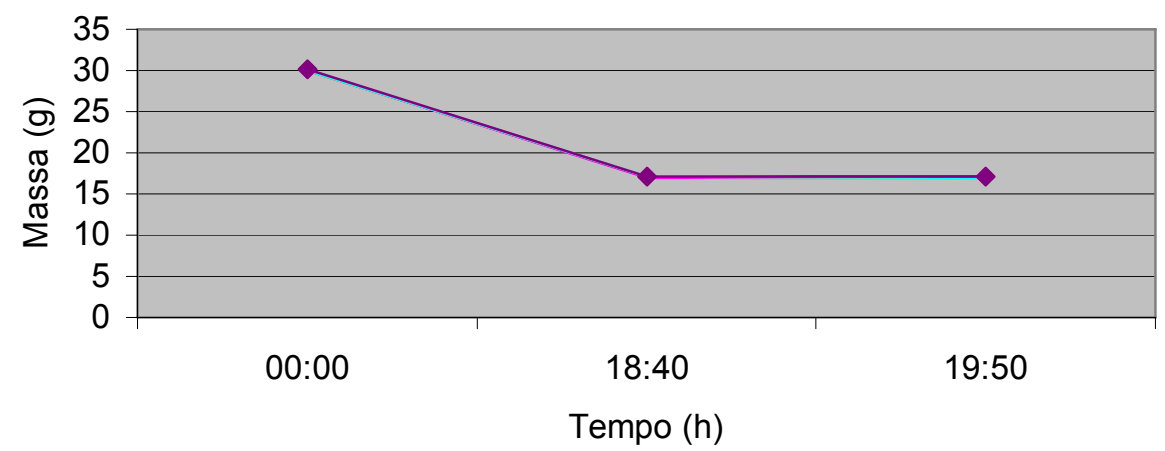

FIGURA 29: Secagem de $30 \mathrm{~g}$ de resina em estufa a $100^{\circ} \mathrm{C}$

Comprovando o valor da massa específica indicado pelo fabricante da resina de $0,690 \mathrm{~g} / \mathrm{L}(39,1 \%),{ }^{(49)}$ na média das amostras houve $39,52 \%$ de evaporação.

Elevar a temperatura da resina seca é necessário para facilitar sua incorporação e homogeneização na matriz betuminosa. Empiricamente, foi possível elevar a temperatura da resina a $140^{\circ} \mathrm{C}$ com a adição de um volume de água destilada entre $15 \%$ e $18 \%$ da massa de resina inicial, sob 3 minutos de irradiação a $100 \%$ da potência de microondas, quando ao final do procedimento, o teor de água retornou a um patamar inferior a $2 \%$ da massa. ${ }^{(55)}$

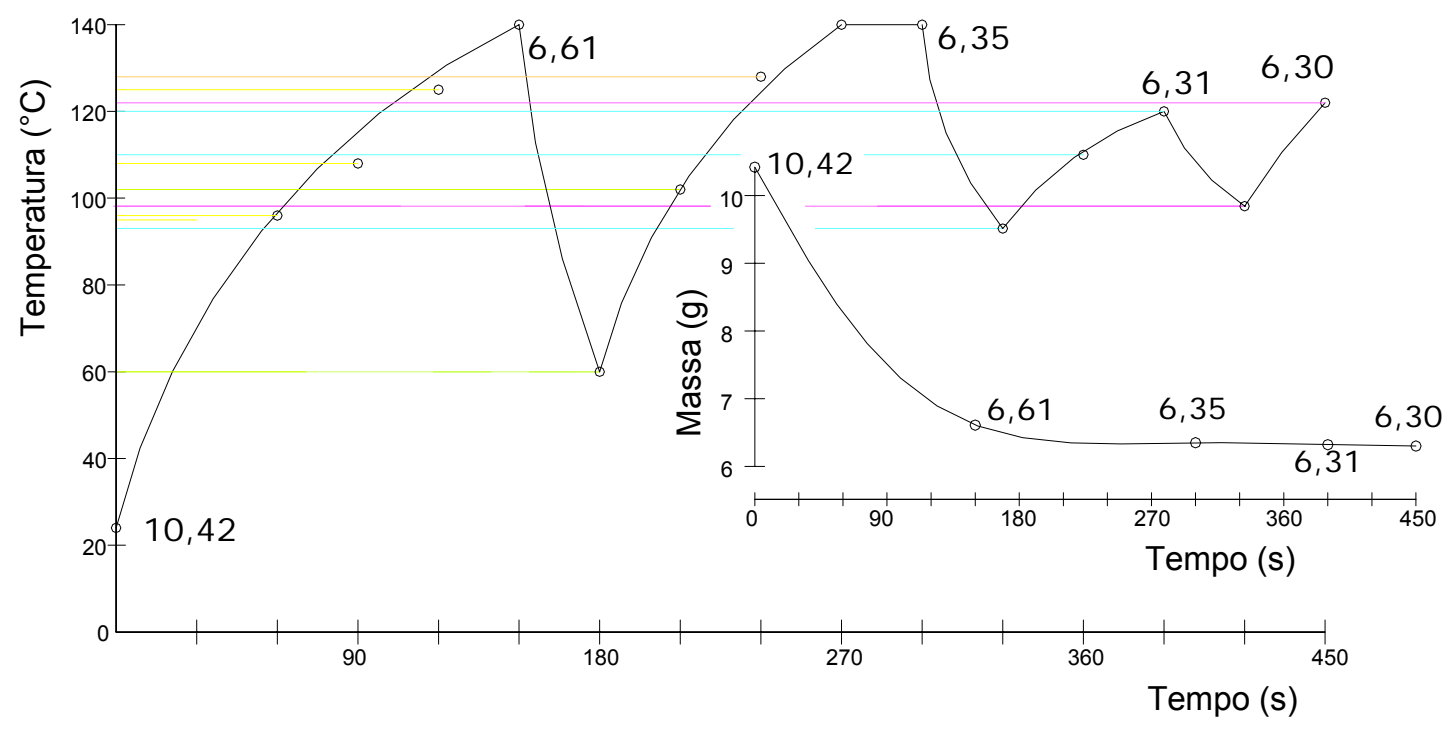

FIGURA 30: Secagem de $10 \mathrm{~g}$ de resina em microondas 
TABELA 8: Resultados dos testes de penetração para amostras da fase 2

\begin{tabular}{|c|c|c|c|c|c|c|c|c|c|}
\hline \multirow[t]{2}{*}{ lote } & \multicolumn{7}{|c|}{ penetração (1/10 mm) } & \multirow{2}{*}{$\begin{array}{c}\text { média } \\
6,58\end{array}$} & \multirow{2}{*}{$\begin{array}{c}\text { desvio } \\
\text { padrão } \\
2,75\end{array}$} \\
\hline & 8,0 & 9,5 & 4,5 & 2,5 & 9,0 & 6,0 & & & \\
\hline \multirow[t]{4}{*}{11} & 9,5 & 6,5 & 8,0 & 4,5 & 8,5 & & & 7,40 & 1,95 \\
\hline & 8,5 & 6,5 & 3,0 & 10,0 & 10,0 & 5,5 & 3,0 & 7,25 & 2,77 \\
\hline & 1,5 & 1,5 & 1,0 & 1,5 & & 6,0 & & 2,30 & 2,08 \\
\hline & 3,5 & 5,0 & 8,0 & 7,0 & 8,0 & 2,0 & 2,0 & 5,58 & 2,50 \\
\hline \multirow[t]{3}{*}{12} & 2,5 & 1,0 & 1,0 & 4,5 & 4,5 & 3,5 & & 2,83 & 1,60 \\
\hline & 5,0 & 5,0 & 1,0 & 1,5 & 1,0 & 8,5 & & 3,67 & 3,03 \\
\hline & 0,5 & 0,5 & 2,0 & 2,5 & 5,0 & 1,5 & & 2,00 & 1,67 \\
\hline \multirow{3}{*}{13} & 3,0 & 2,0 & 2,0 & 2,0 & & & & 2,25 & 0,50 \\
\hline & 1,0 & 1,0 & 1,5 & 1,5 & & & & 1,25 & 0,29 \\
\hline & 2,0 & 2,0 & 4,5 & 5,0 & 5,0 & 1,0 & 7,0 & 3,25 & 1,78 \\
\hline \multirow{5}{*}{14} & 1,0 & 4,5 & 2,0 & 5,0 & 4,5 & 1,0 & 1,5 & 3,00 & 1,87 \\
\hline & 2,0 & 2,0 & 2,0 & 1,0 & & & & 1,75 & 0,50 \\
\hline & 3,0 & 1,0 & 2,0 & 2,0 & & & & 2,00 & 0,82 \\
\hline & 4,0 & 1,5 & 5,0 & 4,5 & 5,5 & 13,0 & 2,5 & 5,58 & 3,89 \\
\hline & 1,0 & 2,0 & 1,0 & 2,0 & 2,0 & & & 1,60 & 0,55 \\
\hline \multirow{5}{*}{15} & 2,0 & 2,0 & 1,5 & 2,0 & 1,5 & & & 1,80 & 0,27 \\
\hline & 4,0 & 1,5 & 2,0 & 4,0 & 2,0 & & & 2,70 & 1,20 \\
\hline & 0,5 & 1,5 & 5,5 & 1,5 & 3,5 & 3,5 & 2,0 & 2,67 & 1,83 \\
\hline & 0,0 & 0,5 & 1,0 & 0,5 & 1,0 & 2,0 & 1,0 & 0,83 & 0,68 \\
\hline & 1,0 & 3,5 & 2,0 & 3,0 & 1,0 & 1,5 & & 2,00 & 1,05 \\
\hline \multirow{3}{*}{16} & 3,5 & 4,0 & 3,0 & 2,5 & 1,5 & & & 2,90 & 0,96 \\
\hline & 5,0 & 6,0 & 6,5 & 7,0 & 3,0 & & & 5,50 & 1,58 \\
\hline & 2,5 & 4,5 & 1,0 & 0,5 & 0,5 & 2,5 & 4,0 & 1,92 & 1,56 \\
\hline \multirow{3}{*}{17} & 4,0 & 3,0 & 4,5 & 2,0 & 4,0 & 1,5 & & 3,17 & 1,21 \\
\hline & 1,0 & 3,0 & 3,0 & 4,0 & 4,5 & & & 3,10 & 1,34 \\
\hline & 2,0 & 2,0 & 2,0 & 2,5 & 2,5 & & & 2,20 & 0,27 \\
\hline \multirow{5}{*}{18} & 2,0 & 1,0 & 1,0 & 1,0 & & & & 1,25 & 0,50 \\
\hline & 9,5 & 3,0 & 4,5 & 1,0 & 5,0 & & & 4,60 & 3,15 \\
\hline & 1,0 & 3,5 & 3,5 & 2,0 & 1,5 & & & 2,30 & 1,15 \\
\hline & 0,5 & 0,5 & 5,0 & 7,5 & 3,5 & 3,5 & 2,0 & 3,42 & 2,69 \\
\hline & 1,0 & 0,5 & 2,0 & 2,5 & 2,0 & 1,0 & & 1,50 & 0,77 \\
\hline \multirow{3}{*}{19} & 4,0 & 5,0 & 5,0 & 7,0 & 5,0 & 18,0 & 2,0 & 7,33 & 5,32 \\
\hline & 2,5 & 4,5 & 1,0 & 1,0 & 1,0 & 3,5 & & 2,25 & 1,51 \\
\hline & 2,0 & 1,5 & 1,5 & 2,0 & 2,0 & 1,5 & & 1,75 & 0,27 \\
\hline
\end{tabular}

Um segundo lote de matrizes ( $n^{\circ} 11$ a 19) foi fundido para incorporação da resina de troca iônica. Os valores obtidos através do ensaio de penetração nas amostras compostas por betume, EVA e resina de troca iônica estão indicados na TAB. 8.

Na FIG. 31, estão representadas em três curvas distintas as médias dos resultados desses ensaios de penetração: na cor rosa, estão indicadas as médias 
de todos os valores de cada lote; na cor amarela, estão indicadas as médias dos valores desconsiderando $20 \%$ dos valores extremos para cada amostra, e a curva azul marca o limite estimado abaixo do qual foram selecionados os dois lotes com menores valores de penetração (lotes 15 e 18). Nessas amostras, foram executadas micrografias das superfícies externa e interna, e com as mesmas proporções, matrizes foram fundidas com rejeitos radioativos para testar sua resistência à lixiviação.

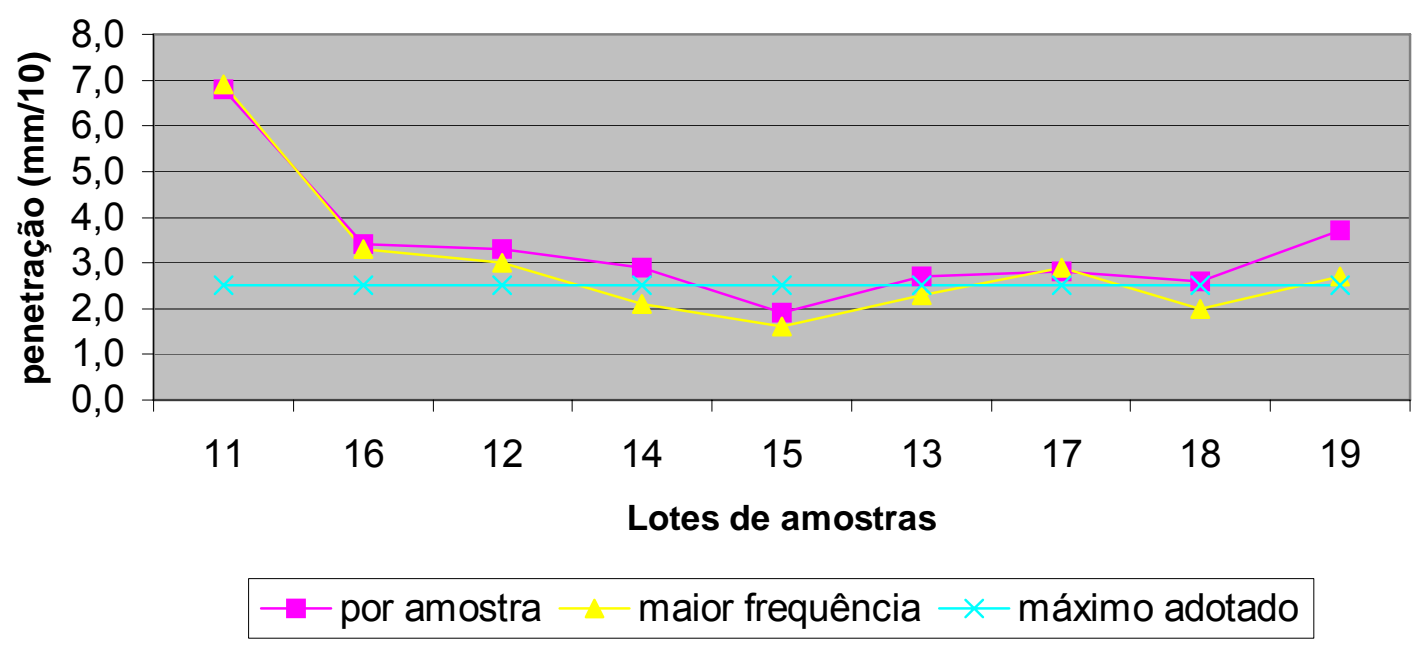

FIGURA 31: Ensaios de penetração em matrizes de betume, resina e EVA a $25^{\circ} \mathrm{C}$

A continuidade e a adesividade do betume enquanto envolve a resina de troca iônica e EVA podem ser observadas na micrografia da matriz 25A, amostra do lote 15 (FIG. 32). O contorno do betume, tanto na superfície, como nas cavidades provavelmente ocasionadas pelo desprendimento de bolhas durante $o$ resfriamento do monolito, não mostra arestas ou fissuras enquanto imobiliza os demais componentes da matriz, característica favorável para os resultados dos ensaios de lixiviação. 

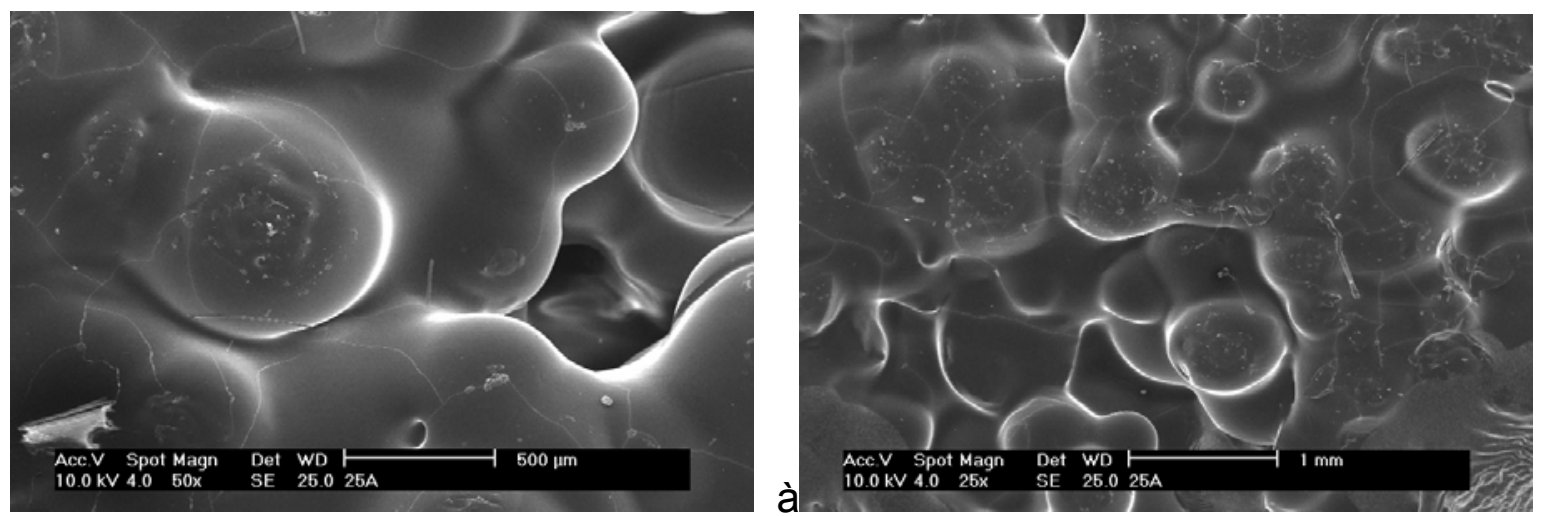

FIGURA 32: MEV da continuidade da superfície do betume sobre a resina

Após análise da micrografia da região interna de uma amostra $28 \mathrm{~A}$ do lote 18 submetida à ruptura com objeto cortante à temperatura ambiente (FIG. 33), pode ser verificado que a interação entre os componentes da matriz acontece pela adesividade do betume sem reação química. $O$ choque causa $O$ deslocamento da resina sem provocar seu desprendimento total. Como a viscosidade do betume depende da temperatura ambiente, pode haver a recuperação natural da abertura.
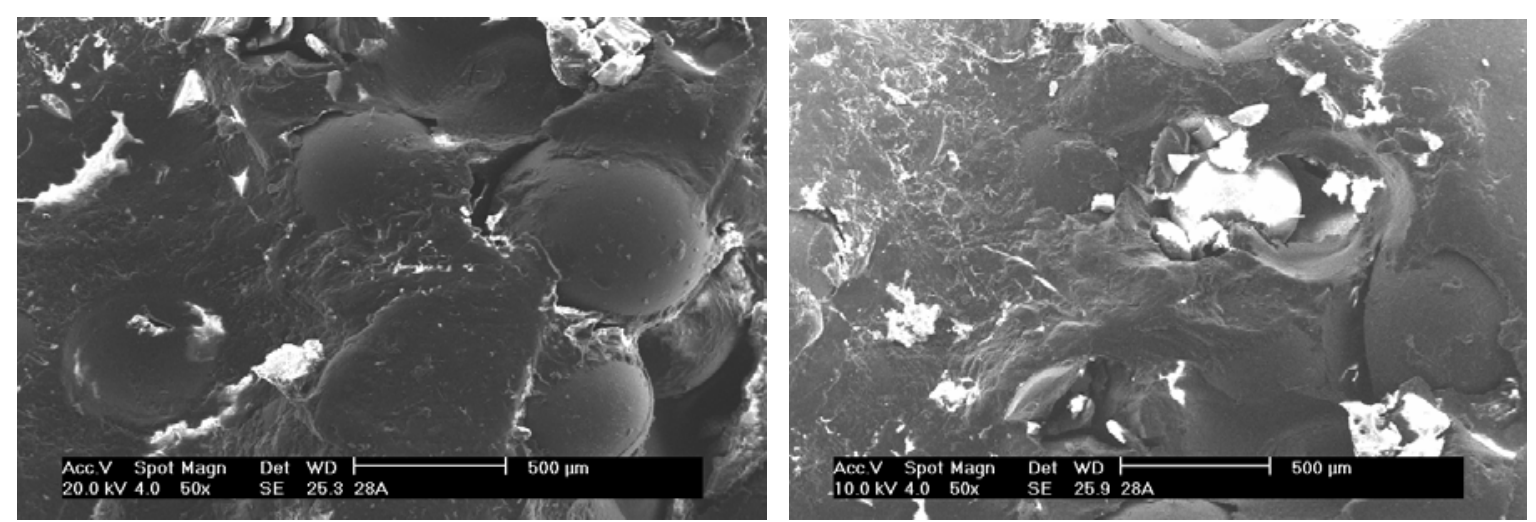

FIGURA 33: MEV da resina envolta pelo betume no interior da matriz

Não houve fuga de radionuclídeos no período em que foi executado o ensaio de lixiviação. Para esse ensaio, foram fundidas três matrizes (FIG. 34) compostas por betume, EVA e resina de troca iônica saturada com ${ }^{65} \mathrm{Zn}$, segundo os passos indicados no item 4.2.2. 


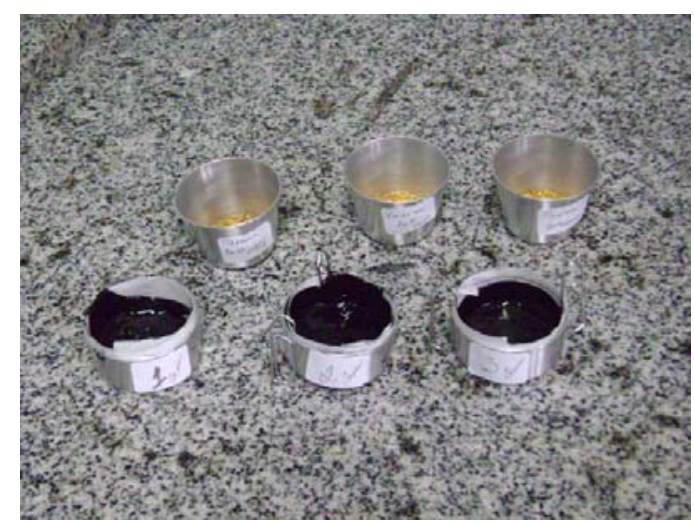

FIGURA 34: Detalhe dos moldes e das resinas saturadas $\mathrm{com}^{65} \mathrm{Zn}$

Cada matriz, separadamente, foi imersa em $1,5 \mathrm{~L}$ de água deionizada (FIG.35). A taxa de lixiviação foi medida pela variação de atividade de radionuclídeos na solução lixiviante, a atividade específica e nos corpos de prova, viabilizando ou não a amostra ANSI/ANS-16.1-2003. ${ }^{(17)}$

As mudanças estruturais do betume pelo envelhecimento, degradação biológica ou efeitos da radiação podem provocar fissuras que tendem a aumentar as taxas de lixiviação, porém campos de radiação de até $10^{7} \mathrm{~Gy}$ não causam danos significativos. ${ }^{(5,56)}$ Os resultados dos testes estão indicados na Tabela 9.

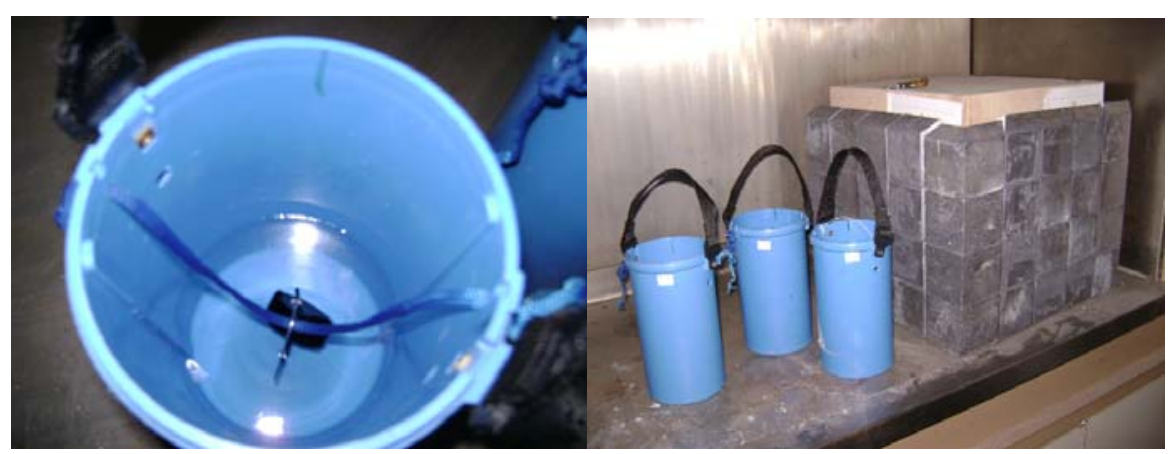

FIGURA 35: Teste de lixiviação, blindagem de chumbo

TABELA 9: Resultados do ensaio de lixiviação

\begin{tabular}{cccccccc}
\hline Amostra & \multicolumn{3}{c}{ Atividade (KBq) } & \multicolumn{3}{c}{ Contagem por semana (KBq) } \\
\cline { 2 - 8 } & Lixiviante & Efluente & Imobilizada & $28 / 08$ & $04 / 09$ & $11 / 09$ & $18 / 09$ \\
\hline 1 & 11,1204 & 3,0297 & 8,0906 & 0 & 0 & 0 & 0 \\
2 & 11,1204 & 3,3429 & 7,7774 & 0 & 0 & 0 & 0 \\
3 & 11,1204 & 3,6552 & 7,4652 & 0 & 0 & 0 & 0 \\
\hline
\end{tabular}


A escolha da borracha incorporada na fase 1 deste trabalho e a definição das porcentagens dos componentes da matriz de imobilização na fase 2 privilegiaram as amostras cujos resultados alcançados nos ensaios de penetração apresentaram os valores mais baixos, amostras de maior dureza. Como o surgimento de rachaduras e fissuras é mais comum em modelos de escala reduzida, se comparados a matrizes na escala $1: 1^{(5)}$, o uso de maquetes permitiu observar o comportamento da matriz final de forma mais crítica comparada a uma matriz de tamanho natural.

Por se tratar de uma tecnologia recente no Brasil, a utilização de microondas em aplicações industriais e em laboratórios de pesquisa tem vários aspectos que merecem um estudo acadêmico mais detalhado, cujos resultados podem ser futuramente implementados em produções de larga escala, possibilitando a otimização dos processos. 


\section{CONCLUSÕES}

Neste trabalho, verificou-se a possibilidade de utilizar altas energias de microondas como fonte de aquecimento de matrizes betuminosas, reforçadas com resíduos de borrachas vulcanizadas, para imobilização de rejeitos radioativos de nível baixo ou médio.

Para o método de incorporação da magnetita, os resultados não se apresentaram satisfatórios, devido à sua alta taxa de aquecimento, em torno de $450^{\circ} \mathrm{C} / 30 \mathrm{~s}$, não ser compatível com a baixa condutividade térmica do betume, que é de aproximadamente $0,17 \mathrm{~W} / \mathrm{m} /{ }^{\circ} \mathrm{C}$. Essa diferença de taxa de aquecimento causou a combustão do betume antes da fusão completa da massa, pela concentração de gases nos vazios do material.

Pelo método de banho externo de magnetita, observou-se que a fusão do betume ocorreu de maneira homogênea, porque a fonte de calor foi distribuída uniformemente em todo o conjunto.

Dos resultados dos ensaios, foi possível verificar que, ao se reforçar a matriz de betume com os outros resíduos poliméricos, as taxas de lixiviação de radionuclídeos continuaram dentro dos parâmetros preconizados pelas normas vigentes.

Todos os testes executados nas amostras, nas diversas fases do desenvolvimento do método de banho de magnetita, serviram para corroborar as expectativas iniciais e poderão, futuramente, ser implementados em produções de larga escala, possibilitando a otimização dos processos de betuminização.

Finalmente, com este trabalho, mais uma alternativa foi encontrada para imobilizar partículas radioativas, evitando sua dispersão e mantendo a integridade do meio ambiente. 


\section{SUGESTÕES PARA TRABALHOS FUTUROS}

Como sugestões para trabalhos futuros, podem ser citadas:

1) Definir os valores ideais de penetração que, ao mesmo tempo, garantam um empilhamento seguro das matrizes sob o ponto de vista da estabilidade física e mantenham as taxas de lixiviação do material imobilizado dentro dos parâmetros exigidos pelas normas vigentes;

2) Automatizar o sistema de alimentação;

3) Automatizar o sistema de homogeneização para operação dentro da cavidade do forno enquanto sob ação das microondas;

4) Instalar uma usina piloto para irradiação contínua;

5) Pesquisar a incorporação de magnetita em uma matriz betuminosa, com relação ao aquecimento com altas energias de microondas, controle da temperatura e eliminação de etapas desnecessárias no processo. 


\section{REFERÊNCIAS BIBLIOGRÁFICAS}

1 COMISSÃO NACIONAL DE ENERGIA NUCLEAR. Licenciamento de Instalações Radiativas. Jun. 02,1998 (CNEN-NE-6.02).

2 COMISSÃO NACIONAL DE ENERGIA NUCLEAR. Gerência de rejeitos radioativos em instalações radiativas. Dez. 17, 1985 (CNEN-NE-6.05).

3 DELLAMANO, J.C. Otimização da etapa de armazenamento de rejeitos radioativos. 2005. Tese (Doutorado) - Instituto de Pesquisas Energéticas e Nucleares, São Paulo.

4 INTERNATIONAL ATOMIC ENERGY AGENCY. The principles of radioactive waste management. Vienna: IAEA, Safety Series n¹11-F, 1995.

5 INTERNATIONAL ATOMIC ENERGY AGENCY. Bituminization processes to condition radioactive waste. Vienna: IAEA, Techinical reports series $\mathrm{n}^{\circ} 352$, 1993.

6 TELLO, C.C.O.; BARROSO, A.C.O. Design and process improvements on the waste treatment of Angra I and Angra II power plants in Brazil. In: $10^{\text {th }}$

INTERNATIONAL CONFERENCE ON NUCLEAR ENGINEERING, April 14-18, 2002, Arlington. Prooceding of ICONE10-22303.

7 INTERNATIONAL ATOMIC ENERGY AGENCY. Requirements and methods for low and intermediate level waste package acceptability, IAEA-TECDOC-864, 1996.

8 SCAGLIUSI, S.R. Estudo do reaproveitamento da borracha de cloropreno pela aplicação da tecnologia de microondas. 2007. Dissertação (Mestrado) - Instituto de Pesquisas Energéticas e Nucleares, São Paulo.

9 HOPSTOCK, D. M., ZANKO, L. M. Minnesota taconite as a microwave absorbing road aggregate material for deicing and pothole patching applications. Minneapolis, Minnesota, ago. 2005. (CTS $05-10$ ).

10 MENEZES, R.R; NEVES, G.A.; FERREIRA, H.C. O estado da arte sobre o uso de resíduos como matérias-primas cerâmicas alternativas. Revista Brasileira de Engenharia agrícola e Ambiental, v. 6, n. 2, p. 303-313, 2002. 
11 US ARMY CORPS OF ENGINEERS, Engineering and Design. Guidance For Low-Level Radioactive Waste (LLRW) and Mixed Waste (MW) Treatment and Handling: engineer manual. Mariland, 30 june, 1997. (EM1110-1-4002). Disponível em: <http://www.usace.army.mil/publications/eng-manuals/em11101-4002/toc.htm>. Acesso em: 25 ago. 2004.

12 CARNEVAROLO JÚNIOR,S.V. Ciência dos polímeros: um texto básico para tecnólogos e engenheiros, São Paulo, S.P.: Artliber Editora, 2002.

13 AGNELLI, J. A. Introdução a materiais poliméricos. In: Núcleo de excelência em reologia e processamento de polímeros. São Carlos, SP: Universidade Federal de são Carlos. 2002. Mod. 1. (Curso ministrado na UFISCAR).

14 PIVA, A.M.; WIEBECK, H. Reciclagem do plástico, São Paulo, S.P.: Artliber Editora, 2004.

15 SENÇO, W. Pavimentação. São Paulo, S.P.: Grêmio Politécnico, 1974.

16 PICCHI, F.A. Impermeabilização de coberturas. São Paulo, S.P.: Editora PINI, 1986.

17 GUZELLA,M.F.R.;SILVA,T.V. Evaluation of Bitumens for Radioactive Waste Immobilization. In: WASTE MANAGEMENT 2001 SYMPOSIUM, February 25March 1, 2001, Tucson. Proceedings... Disponível em:

<http://WWW.wmsym.org/Abstracts/2001/21D/21D-35.pdf > Acesso em: 25 ago. 2006.

18 GARCIIA-MORALES, M.; Partal, P.; Navarro, F. J.; Gallegos, C. Effects of waste polymer addiction on rheology of modified bitumen. Fuel, v. 85, i. 7-8, p. 936-943, 2006.

19 TUCKER JUNIOR, R. F.; NELSON, R. A. Radioactive Waste Technology. New York, NY: A. Alan Moghissi, Herschel W. Godbeew, Sue A. Hobart. Solidification, packaging, and volume reduction, cap. 9, p. 351-375.

20 HUNG, L.C. Imobilização de resinas de troca iônica em polímeros. 1994. Dissertação (Mestrado) - Instituto de Pesquisas Energéticas e Nucleares, São Paulo.

21 ABRÃO, A. Operações de troca iônica. São Paulo: IEA, [s.d.] (Disciplina de pós-graduação em química QFL - 754).

22 ORTIZ, N. Estudo da utilização de magnetita como material absorvedor dos metais Cu2+, Pb2+, Ni2+ e Cd2+, em solução. 2000. Tese (Doutorado) Instituto de Pesquisas Energéticas e Nucleares, São Paulo. 
23 BENNETT, D.G.; HIGGO, J. J. W.; WICKHAM, S.M. Review of Waste Immobilisation Matrices. Oakham: 2001, p.3-10.

(<http://www.nirex.co.uk/foi/corwm/corwm28.pdf>).

24 COMISSÃO NACIONAL DE ENERGIA NUCLEAR. Diretrizes Básicas de Proteção Radiológica. Jan. 06,2005 (CNEN-NE-3.01).

25 CARDOSO, E. M. Programa de integração CNEN. Módulo Informação Técnica. Rio de Janeiro: CNEN, 2003. Disponível em:

<HTTP://www.cnen.gpv.br/ensino/apostilas/PIC.pdf> Acesso em: 24 out. 2007.

26 COMISSÃO NACIONAL DE ENERGIA NUCLEAR - BRASIL. Rejeitos Radioativos. Rio de Janeiro: CNEN, Nov. 2001. Disponível em:

$<$ HTTP://protecaoradiologica.unifesp.br/download/rejeitos.pdf> Acesso em: 23 out. 2007.

27 DANTAS, V. A verdade sobre os rejeitos nucleares. Tratamento e controle. Brasil Nuclear, ano 13, n. 31, p. 18-21, 2007.

28 CARVALHO, R.P. Microondas, São Paulo, SP.: Editora Livraria da Física: Sociedade Brasileira de Física, 2005.

29 CLARK, D. E.; FOLZ, D. C. Microwave Processing of MaterialS. In: 10TH INTERNATIONAL CERAMICS CONGRESS AND THIRD FORUM ON NEW MATERIALS, July 14-18, 2002, Florence. Proceedings... Florence: VPI, 2002, p. $367-380$.

30 HAQUE, K.E. Microwave energy for mineral treatment processes - a brief review. International Journal of Mineral Processing, v. 57, p. 1-24, 1999.

31 RAKHMANKULOV, D.L.; SHAVSHUKOVA, S.Y.; LATYPOVA, F.N.; ZORIN, V.V. Laboratory and industrial applications of microwave techniques. Russian Journal of Applied Chemistry (Translated from Zhurnal Prikladnoi Khimii), v. 75, n. 9, p. 1377-1383, 2002.

32 GABRIEL,C.; GABRIEL, S.; GRANT,E.H.; HALSTEAD,B.S.J.; MINGOS,D.M.P. Dielectric parameters relevant to microwave dielectric heating. Chemical Society Rewiels, v.27, p. 213-223, 1998.

33 THOSTENSON, E.T.; CHOU, T.-W. Microwave processing: fundamentals and applications. Composites: Part A - Applied Science and Manufacturing, v. 30, i. 9, p.1055-1071, 1999. 
34 JEON, J.Y.; KIM, H.Y. Microwave irradiation effect on diffusion of organic molecules in polymer. European Polymer Journal, v.36, i. 5, p.895-899, 2000.

35 EL HARFI, K.; MOKHLISSE, A.; CHANÂA, M.B.; OUTZOURHIT, A. Pyrolysis of the Moroccan (Tarfaya) oil shales under microwave irradiation. Fuel, v. 79, i. 7, p. 733-742, 2000.

36 JONES, D.A.; LELYVELD, T.P.; MAVROFIDIS, S.D.; KINGMAN, S.W.; MILES, N.J. Microwave heating applications in environmental engineering - a review. Resources, Conservation and Recycling, v. 34, i.2, p.75-90, 2002.

37 BJORNDALEN, N.; ISLAM, M.R. The eflect of microwave and ultrasonic irradiation on crude oil during production with a horizontal well. Journal of Petroleum Science and Engineering, v. 43, i. 3-4, p.139-150, 2004.

38 KRISHNAN, J.M.; RAJAGOPAL, K.R. On the mechanical behavior of asphalt. Mechanics of Materials, v. 37, i. 11, p. 1085-1100, 2005.

39 REED D.; LORENTZEN P. E.; KRISSOFF, M. R.; NATH, R., H. Microwave Process for Asphalt Pavement Recycling, Publicado por EPRI Industrial Program - Environment \& Energy Management n², 1992.

40 PERIC, A.D.; PLECAS,'I. B.. PAVLOVIC R. S. Influence of the incorporation of high-and low-density polyethylene granules in mortar matrices on the characteristics of solidified radioactive waste. Environment International, v. 22 ,i. 6, p. 729-736, 1996.

41 KALB, P. D. Hazardous and Radioactive Waste Treatment, Technologies Handbook, Brookhaven National Laboratory - bnl- 68581, cap. 6.5, p. 1-14, 2001.

42 EVANS, R.; QUACH, A.; BIRNIE, D. P.; SÁEZ, A. E.; ELA, W. P.; ZELINISK, B. J. J.; XIA, G.; SMITH, H. Development of polymeric waste forms for the encapsulation of toxic waste using emulsion-encapsulation based process.

U.S. Journal of Undergraduate Research, v. 3, p.56-63, 2003.

43 ZAKRZEWSKA-TRZNADEL, G.; HARASIMOWICZ. M. Application of ceramic membranes for hazardous wastes processing: pilot plant experiments with radioactive solutions. Desalination, v. 162, p. 191-199, 2004.

44 PLECAS, I.; PAVLOVIC, S. Leaching behavior of ${ }^{60} \mathrm{Co}$ and ${ }^{137} \mathrm{Cs}$ from spent lon Exchange Resins in Cement- Bentonite Clay Matrix. Journal of Nuclear Materials, v. 327, p. 171-174, 2004. 
45 WESTINGHOUSE SAVANNAH RIVER COMPANY (Aiken). Sherrod L. Maxwell,III; Sheldon T. Nichols. Method for digesting spent ion exchange resins and recovering actnides therefrom using microwave radiation. US n. PN 5945342, May 18, 1998, Aug. 31, 1999.

46 Materiais: solados e palmilhas de montagem. Série: Literatura técnica básica em calçados. CTCCA - Centro Tecnológico do Couro, Calçados e Afins, Novo Hamburgo, v. 1, p. 56-71, 2002.

47 PERFITÉCNICA-PERFÍS TÉCNICOS DE BORRACHA: Silicone. Catálogo do fabricante. [s.d.], São Paulo.

48 Viapol Ltda.: Vit 90 Cimento asfáltico. Catálogo do fabricante. [s.d.], São Paulo.

49 ROHM AND HAAS COMPANY. Amberlite IRN217- Industrial Nuclear Grade Mixed Bed Resin. Catálogo do fabricante. São Paulo, 2006.

50 ASSOCIAÇÃO BRASILEIRA DE NORMAS TÉCNICAS. Materiais betuminosos: determinação da penetração. Rio de Janeiro: ABNT, 1998. (NBR 6576).

51 REIS, M. Um estudo da influência da granulometria dos agragados no desempenho do microrevestimento asfáltico a frio quanto ao deslocamento lateral e vertical. 2005. Dissertação (mestrado) Universidade Estadual de Campinas, São Paulo.

52 ASSOCIAÇÃO BRASILEIRA DE NORMAS TÉCNICAS. Materiais betuminosos: determinação do ponto de amolecimento - Método do anel e bola. Rio de Janeiro: ABNT, 2000. (NBR 6560).

53 ASSOCIAÇÃO BRASILEIRA DE NORMAS TÉCNICAS. Derivados de petróleo: determinação dos pontos de fulgor e de combustão em vaso aberto Cleveland. Rio de Janeiro: ABNT, 2004. (NBR11341).

54 SUARES, A. A. Lixiviação de rejeitos imobilizados. São Paulo: IPEN Instituto de Pesquisas energéticas e Nucleares, Jan. 1989. (IPEN PUB - 236).

55 GUZELLA, M.F.R.; QUILICI, V. Determinando o teor de água em produtos de rejeito. Banas Metrologia on Line, Belo Horizonte, Ago. 2005. Disponível em: http://www.banasmetrologia.com.br/textos.asp?codigo=990\&secao=revista Acesso em 10 Jul 2006. 
56 NEILSON JUNIOR, R. M.; DOLE L. R. Radioactive waste technology. New York, NY: Moghissi, A.A.; Godbee, H. W.; Hobart, S.A. (Ed) cap 8, chemical considerations for the immobilization of low-level radioactive waste. P. 317349. 1986. 